Published in final edited form as:

Physiol Genomics. 2008 January 17; 32(2): 229-253.

\title{
Transcriptional Profiling of Native Inner Medullary Collecting Duct Cells from Rat Kidney
}

\author{
Panapat Uawithya, Trairak Pisitkun, Brian E. Ruttenberg, and Mark A. Knepper \\ Laboratory of Kidney and Electrolyte Metabolism, National Heart, Lung and Blood Institutes, \\ National Institutes of Health, Bethesda, MD 20892, USA
}

\section{Abstract}

Vasopressin acts on the inner medullary collecting duct (IMCD) in the kidney to regulate water and urea transport. To obtain a 'parts list' of gene products expressed in the IMCD, we carried out mRNA profiling of freshly isolated rat IMCD cells using Affymetrix Rat 2302.0 microarrays with approximately 31,000 features. 7913 annotated transcripts were found to be expressed above background in the IMCD cells. We have created a new online database (the "IMCD Transcriptome Database" $\dagger$ ) to make the results publicly accessible. Among the 30 transcripts with the greatest signals on the arrays were three water channels: aquaporin-2, aquaporin-3, and aquaporin- 4 , all of which have been reported to be targets for regulation by vasopressin. In addition, the transcript with the greatest signal among members of the solute carrier (SLC) family of genes was the UT-A urea transporter (Slc14a2), which is also regulated by vasopressin. The V2 vasopressin receptor was strongly expressed, but the V1a and V1b vasopressin receptors did not produce signals above background. Among the 200 protein kinases expressed, the serum-glucocorticoid regulated kinase $(S g k l)$ had the greatest signal intensity in the IMCD. WNK1 and WNK4 were also expressed in the IMCD with a relatively high signal intensity as was protein kinase $A$ ( $\beta$-catalytic subunit). In addition, a large number of transcripts corresponding to AKAPs and 14-3-3 proteins (phospho-S/T binding proteins) were expressed. Altogether, the results combine with proteomics studies of the IMCD to provide a framework for modeling complex interaction networks responsible for vasopressin action in collecting duct cells.

\section{Index words}

Oligonucleotide array; vasopressin; aquaporin-2; urea transport; kinases

\section{INTRODUCTION}

The inner medullary collecting duct (IMCD) is the terminal portion of the collecting duct system of the kidney. The collecting duct system represents the final site of adjustment of urinary composition and volume, and therefore is critical for extracellular fluid homeostasis. An important regulator of collecting duct transport function is vasopressin, which controls both water and urea transport $(21 ; 53)$

To address the mechanisms of vasopressin signaling in the renal IMCD, we have been following a "systems-biology" approach consisting of identification of the component proteins via protein mass spectrometry-based analysis $(2 ; 29 ; 30 ; 62 ; 71 ; 102)$, and antibody-based quantification of protein abundance (41), coupled to computational analysis of the identified

\footnotetext{
$\dagger_{\text {http://dir.nhlbi.nih.gov/papers/lkem/imcdtr/ }}$

Corresponding author: Mark Knepper, National Institutes of Health, 10 Center Dr, Bldg 10, Room 6N260, Bethesda, MD 20892-1603, Phone: (301) 496-3064, E-mail: Knepperm@nhlbi.nih.gov.
} 
proteins to discover signaling networks involved in IMCD regulation (30). An important product of these studies is the generation of a 'parts list', the IMCD proteome, that includes the signaling apparatus (http://dir.nhlbi.nih.gov/labs/lkem/rm/proteomics_db.asp). The IMCD proteome database currently is made up of 2338 proteins identified at high stringency.

Despite the success so far of the proteomics approach, proteomics methodologies have limitations that make it unlikely that all of the proteins that play important roles in vasopressin signaling will be found. Limited sensitivity is the chief factor. In the present study, in order to augment our enumeration of an 'IMCD parts list', we have pursued an analysis of the IMCD transcriptome using Affymetrix oligonucleotide arrays. The studies were carried out in native IMCD cells freshly isolated from rat inner medullas. The arrays contain approximately 31,000 features representing most of the expressed genes in the rat genome. Although the approach is comprehensive, the chief objective is to determine what transcripts are expressed in functional categories most relevant to vasopressin signaling related to short- and long-term regulation of water and urea transport in the IMCD.

The new data from the present study add to transcriptomic data obtained in microdissected cortical and outer medullary collecting ducts using a micro-SAGE technique (9). SAGE data, however, are not available for the IMCD. Early approaches to transcriptional profiling in IMCD involved large-scale sequencing of cDNAs prepared from microdissected IMCD segments, an approach that was informative but not comprehensive (78). A number of studies have also reported transcriptional profiling of whole inner medulla $(7 ; 8 ; 51 ; 66 ; 80)$, which contain IMCDs as well as loops of Henle, vasa recta, capillaries and interstitial cells. IMCDs make up about $40 \%$ of the inner medullary tissue by volume (40). In the present study, we carry out transcriptional analysis of biochemically enriched IMCD cells isolated from rat renal inner medulla.

\section{METHODS}

\section{Animals}

Pathogen-free male Sprague-Dawley rats weighing 100-120 grams (Taconic Farms Inc. Germantown, NY) were maintained on an autoclaved pelleted rodent diet and ad libitum drinking water (NHLBI Animal Care and Use Committee approved protocol number H-0110). The age of the rats was chosen to match the age of rats typically used for our isolated perfused tubule studies (12).

\section{Preparation of IMCD and non-IMCD cell suspensions}

IMCD and non-IMCD cells were prepared from whole inner medullas as previously described (62) with slight modification (Figure 1 and Supplementary Methods).

In order to assess purity of IMCD samples, aliquots from each cell suspension were loaded onto SDS-polyacrylamide gels and immunoblotting was carried out as described (12). An immunoblot for a collecting duct marker AQP2 (Figure 2 panel A) demonstrated that AQP2 was indeed highly enriched in the IMCD fraction and depleted from the non-IMCD fraction (Band densities: IMCD fraction, 412; non-IMCD fraction, 45). An immunoblot for AQP1, a marker of vasa recta and thin descending limbs of Henle (Figure 2 panel B), demonstrated that there was relatively little contamination of the IMCD fraction from non-IMCD elements (Band densities: IMCD fraction, 1.4; non-IMCD fraction, 29.4). Lack of contamination by outer medullary cells was demonstrated by immunoblotting using an antibody to $\mathrm{NKCC} 2$, a marker of the outer medullary thick ascending limb (Figure 2 panel C) (Band densities: IMCD fraction, 0.9; non-IMCD fraction, 0.4; OMCD fraction, 11.3). 


\section{Total RNA extraction}

Total RNA of IMCD and non-IMCD cells was extracted using Trizol reagent (Invitrogen, Carlsbad, CA) following the manufacturer's protocol. Full details are reported in the Supplementary Methods. Typically, for IMCD, the yield was $1 \mu \mathrm{g}$ per kidney and, for nonIMCD, the yield was $0.7 \mu \mathrm{g}$ per kidney.

\section{Oligonucleotide microarrays}

Hybridization probes (labeled cDNAs corresponding to the transcripts) were prepared and hybridized to the Affymetrix Rat Genome 2302.0 microarrays (Affymetrix Inc, Santa Clara, CA) according to the manufacturer's protocols. See Supplementary Methods for full details.

\section{Microarray data analysis and identification of IMCD and non-IMCD transcribed genes}

The total number of genes with the Affymetrix Detection p-value consistent with a "Present Call" (detected) was about 17,000 from 31,000 features in the Affymetrix Rat Genome 230 2.0 array for both IMCD and non-IMCD samples. These 17,000 features corresponded to about 10,200 distinct genes. The remaining 14,000 features were identified to have "Absent" (not detected) or "Marginal" Calls based on the Detection p-value from Affymetrix GCOS software. Intensities of each probe set were normalized by median-transformed normalization.

The IMCD and non-IMCD samples contain a relatively small amount of contaminating cells from non-IMCD elements and IMCD elements, respectively (see AQP1 and AQP2 immunoblots in Figure 2). We calculated corrected values for mRNA signals using estimates of cross contamination. The appropriate equations are (see Supplementary Methods for derivation):

$$
\begin{aligned}
& \mathrm{IMCD}_{\text {corrected }}=\left(\mathrm{d} \cdot \mathrm{IMCD} \mathrm{Dobserved}_{-\mathrm{b}} \mathrm{b} \cdot \text { non- }-\mathrm{IMCD}_{\text {observed }}\right) /(\mathrm{ad}-\mathrm{bc}) \quad(\text { Equation } 1) \\
& \text { non- } \left.\mathrm{IMCD}_{\text {corrected }}=\left(\mathrm{a} \cdot \mathrm{non}-\mathrm{IMCD}_{\text {observed }}-\mathrm{c} \cdot \mathrm{IMCD}_{\text {observed }}\right) /(\mathrm{ad}-\mathrm{bc}) \quad \text { (Equation } 2\right) \\
& \text { where, }
\end{aligned}
$$

$\mathrm{IMCD}_{\mathrm{observed}}=$ the normalized signal intensity for a given feature for IMCD sample;

and

non-IMCD $\mathrm{Ibserved}=$ the normalized signal intensity for the same feature for the corresponding non-IMCD sample;

and

$\mathrm{a}=$ fraction of the total signal in IMCD samples from IMCD cells

$\mathrm{b}=$ fraction of the total signal in IMCD samples from non-IMCD cells

$\mathrm{c}=$ fraction of the total signal in non-IMCD samples from IMCD cells

$\mathrm{d}=$ fraction of the total signal in non-IMCD samples from non-IMCD cells.

Note also that $\mathrm{a}+\mathrm{b}=1$ and $\mathrm{c}+\mathrm{d}=1$.

The cross contamination values a, b, c, and d could in principle be estimated from the AQP1 and AQP2 immunoblots but a more general approach is to use the array data to determine the required cross contamination correction. Supplementary Figure 3 shows a histogram of the ratios of normalized, but uncorrected, IMCD-to-non-IMCD signal ratios for individual features 
on the array. In theory, the maximum and minimum ratios should be bounded at a distinct value determined by the degree of cross contamination. The maximum and minimum ratios in principle could then be used to estimate the degree of cross contamination. However, as seen in Supplementary Figure 3, there is considerable splay in the tails of the ratio histogram, indicating that a direct choice of single unique values for cross contamination is not feasible. Consequently, we chose an alternative approach in which we chose a set of transcripts corresponding to IMCD and non-IMCD marker proteins. These are transcripts known to be exclusively or predominantly expressed in the IMCD ("IMCD markers) and transcripts known to be expressed in non-IMCD structures but not in the IMCD itself ("non-IMCD markers"). Thus, we choose values for $\mathrm{a}, \mathrm{b}, \mathrm{c}$, and $\mathrm{d}$ such that the mean value for [non-IMCD $\mathrm{I}_{\text {corrected }}$ ] is zero for a selected set of IMCD markers and the mean value for $\left[\mathrm{IMCD}_{\text {corrected }}\right]$ is zero for a selected set of non-IMCD markers. For IMCD markers, we have chosen aquaporin-3 (Aqp3), gamma $\mathrm{ENaC}$ (Scnnlg), ClC-K2 (Clcnkb), the vasopressin V2 receptor (Avpr2) and frizzled receptor $1(F z d l)$. For non-IMCD markers, we have chosen UT-B (Slc14al, expressed in vasa recta), NHE3 (Slc9a3, expressed in thin descending limb of Henle), von Willebrand's factor ( $V w f$, expressed in endothelial cells of vasa recta) and EEAC1 (Slclal, expressed in thin limbs of Henle's loop). Calculated in this way, the resulting values for $b$, c, and d were: $a=0.80 \pm$ $0.00, \mathrm{~b}=0.20 \pm 0.00, \mathrm{c}=0.27 \pm 0.01$ and $\mathrm{d}=0.73 \pm 0.01$.

Equations 1 and 2 were applied to each feature to gain corrected signal intensities that would be expected if the samples were pure IMCD and non-IMCD suspensions. The signal intensities for IMCD and non-IMCD are reported as mean \pm SE for all replicates.

\section{RESULTS AND DISCUSSION}

The general strategy employed in this study was to use Affymetrix microarrays to profile gene expression at an mRNA level in rat IMCD cells, focusing on the general question: What gene products can be identified in the IMCD that could be components of the pathways and networks involved in regulation of aquaporin-2 and osmotic water permeability in the IMCD? The data presented are calculated from the results of 6 microarray chip sets, i.e. 3 pairs of IMCD vs. non-IMCD transcripts. Total RNA samples for each pair were isolated from 7 rats (14 inner medullas). A full listing of the results is shown in Supplementary Table S1 and the full results have also been deposited in the GEO database (GSE7891: at http://www.ncbi.nlm.nih.gov/geo/query/acc.cgi?token=rbyjrsiskikmeze\&acc=GSE7891). 7913 annotated transcripts (compared to 10,206 total transcripts above background) were found to be expressed above background in the IMCD cells.

We have created a new online database (the "IMCD Transcriptome Database" at http://dir.nhlbi.nih.gov/papers/lkem/imcdtr/) to provide ready access to these data. This site also includes the data in a downloadable format and a BLAST facility for searching for a particular transcript in the database.

The variability of the normalized, corrected signals for the three experiments is shown as scattergrams in Supplementary Figure 4. As can be seen, the distribution of IMCD and nonIMCD signals were reproducible with more than $85 \%$ of IMCD features and more than $80 \%$ of non-IMCD features showing coefficients of variation $(\mathrm{CV}=$ variance/mean $\times 100 \%)$ less than $15 \%$. Supplementary Figure 5 shows mean corrected, normalized signals for IMCD plotted against the non-IMCD values for the same features. Values that deviate from the diagonal indicate transcripts selectively expressed in IMCD (above line) or non-IMCD elements of inner medulla (below line). Supplementary Figure 6 shows the corrected values for IMCD plotted against the corresponding non-corrected values. As can be seen, the corrections were generally relatively small. Only 0.8 percent of the values had correction factors of $50 \%$ or more of the uncorrected values. 
In the following, we present a series of tables showing, for specific categories of gene products, what transcripts in IMCD cells are associated with the highest signals on the microarrays along with comments regarding gene products that are thought to be involved in vasopressin action in the IMCD. We also include significant negatives in which corrected signals in the IMCD were indistinguishable from zero. The classification of expressed genes in each table was based on classification terms from the PANTHER Database (83) and the Rat Genome Database (87). We emphasize that the signals from the array provide a general index of relative expression levels for individual transcripts but do not necessarily correlate with the absolute level of the specific mRNA in the cells. Furthermore, transcript level does not necessarily correlate with protein expression level owing to differences in translation rate and protein stability among various proteins (7).

\section{G-protein coupled receptors}

Table 1 summarizes the microarray results for G-protein coupled receptors. Normalized and corrected intensity values reported in all tables are calculated from the raw data as described in the Methods section. The value of 1.0 represents the median value for all positive transcripts in the IMCD. A number of receptors with well established roles in the IMCD were identified and had substantial signals on the arrays. These were the vasopressin V2 receptor, the frizzled receptor 1, the $\mathrm{PGE}_{2}$ receptor $\mathrm{EP} 1$, the endothelin $\mathrm{B}$ receptor, the adenosine $\mathrm{A} 1$ receptor, the adrenergic receptor $2 \mathrm{a}$, the frizzled receptor 6 , the adrenergic receptor $1 \mathrm{~d}$, the $\mathrm{PGE}_{2}$ receptor EP4, and the nucleotide receptor P2Y2. Of these, only the vasopressin V2 receptor (53) and the prostaglandin $\mathrm{E}_{2}$ receptor $\mathrm{EP} 4$ (5) are known to be coupled to the heterotrimeric G-protein $\mathrm{G}_{\mathrm{s}}$ and to generate cyclic AMP when bound to ligand. Presumably, $\mathrm{PGE}_{2}$ does not increase water permeability in the IMCD because of the prevailing inhibitory effect of the EP1 receptor, which signals via $\mathrm{G}_{\alpha \mathrm{qq}}$. In addition to receptors with well-established roles, a number of other G-protein coupled receptors were identified in the IMCD (Table 1), providing hypotheses for further study. For example, the chemokine orphan receptor 1 (Cmkor1) is the highest ranked receptor from the point of view of normalized intensity.

In our previous study, vasopressin-induced cAMP production was inhibited by epinephrine or the $\alpha 2$-agonist clonidine, but not by the $\alpha 1$-agonist, phenylephrine (46). This finding is consistent with the present finding of dominant expression of the $\alpha 2 \mathrm{a}$-adrenergic receptor relative to the $\alpha 1$-adrenergic receptor as shown in Table 1 . In contrast, $\beta$-adrenergic receptor expression was below background.

The adenosine receptor A1 is associated with a high signal intensity on the IMCD arrays (Table 1). It has been shown that adenosine analogues can decrease water permeability induced by arginine vasopressin (18). Our previous experiments using the adenosine A1 agonist NPEA $\left(\mathrm{N}^{6}-2\right.$-phenylethyladenosine) showed an increase in intracellular $\mathrm{Ca}^{2+}$ concentration and this effect was inhibited by the selective adenosine A1 antagonist 8-phenyltheophylline (17).

Endothelin-1 can induce diuresis in part by inhibiting water reabsorption induced by arginine vasopressin in the IMCD (60). In the IMCD, it has been demonstrated by immunofluorescence and RT-PCR that the endothelin B receptor is the predominant endothelin receptor subtype in agreement with our microarray data $(42 ; 81)$.

Purinergic P2Y2 receptors have been demonstrated in the rat IMCD (38). Binding of ATP or UTP to P2Y2 receptors increase intracellular calcium in the IMCD, decreasing water permeability (17). This inhibition of water permeability might occur through activation of protein kinase $\mathrm{C}$ and reduction of cellular cAMP levels (37).

Arginine vasopressin receptors are of two types, V1 and V2 receptors. From the microarray analysis, the signal intensity corresponding to the $\mathrm{V} 1 \mathrm{a}$ and $\mathrm{V} 1 \mathrm{~b}$ receptors in the IMCD cells 
was negligible. In contrast, V2 receptor signal intensity was relatively high. This evidence supports our previous finding that $\mathrm{V} 2$ receptors, but not $\mathrm{V} 1$ a receptors, are expressed in the $\operatorname{IMCD}(16 ; 45)$.

\section{Heterotrimeric G-proteins}

Table 2 shows heterotrimeric G-protein subunits expressed in the IMCD. The $\alpha$ subunits expressed include three inhibitory $\alpha$ subunits $\left(\mathrm{G}_{\alpha \mathrm{i}}\right)$ which regulate adenylyl cyclases in an inhibitory fashion, the stimulatory $\alpha$ subunit $\left(G_{\alpha S}\right)$ which stimulates adenylyl cyclases, $G_{\alpha q}$ which couples to phospholipase $\mathrm{C} \beta$ ( $\mathrm{PLC}_{\beta}$ ) isoforms and $\mathrm{G}_{\alpha 12}$, an activator of Rho-GEF (43) and a regulator of the actin cytoskeleton. All are potentially involved in vasopressin signaling.

\section{Nucleotide cyclases}

Only 3 adenylyl cyclase transcripts of the 10 known genes were identified in the IMCD samples, namely Adcy6 and Adcy3 previously identified in the IMCD (28), as well as Adcy9 as shown in Table 3. In addition, soluble guanylyl cyclase 1 was identified, which functions as a nitric oxide receptor and transducer. Interestingly, there was no significant signal for any of the three nitric oxide synthase (NOS) isoforms in the IMCD samples, although NOS3 (endothelial NOS) was detected in the non-IMCD samples (Table 16). However, previous qualitative RT-PCR studies in microdissected IMCD segments demonstrated the presence of NOS1, 2 and 3 mRNA (96). Furthermore, both NOS1 (102) and NOS2 (91) protein has been detected in the IMCD by protein mass spectrometry.

\section{Cyclic nucleotide phosphodiesterases}

As shown in Table 4, the predominant cyclic nucleotide phosphodiesterase transcripts correspond to the type 4 and type 1 classes, consistent with pre-existing findings (15;75). Type 4 phosphodiesterases (PDE4A, PDE4B, PDE4C, and PDE4D, coded by separate genes) are cAMP-specific and inhibitable by rolipram. Type 1 phosphodiesterases hydrolyze both cAMP and cGMP and are calmodulin-dependent. No significant signal was found for PDE5, which has been implicated in regulation of aquaporin-2 trafficking in more proximal collecting duct segments (4).

\section{Protein kinases}

There are more than 500 genes coding for protein kinases in mammalian genomes (48). As shown in Table 5, a large number of these are expressed in the IMCD. There were 93 serine/ threonine kinases with signals above the median value in the IMCD (corrected signal above 1.0, Table 5A). Serum-glucocorticoid regulated kinase, sgk1, a serine/threonine kinase closely related to protein kinase $\mathrm{B}(A k t l)$, is the kinase with greatest signal intensity in the IMCD (Table 5A). This kinase is strongly regulated by the mineralocorticoid hormone aldosterone (11). WNK1 and WNK4, two kinases implicated in regulation of ion transport in more proximal parts of the renal tubule $(95 ; 99)$, are also expressed in the IMCD with a relatively high signal intensity. Protein kinase A (catalytic $\beta$ subunit), long recognized as a major element of vasopressin signaling, is also associated with a high signal intensity on the IMCD arrays. Additional protein kinases with proposed roles in vasopressin signaling have relatively high signal intensities including protein kinase $\mathrm{B}(A k t 1)$, protein kinase $\mathrm{C}$ (iota, zeta, nu and epsilon), casein kinase isoforms, calmodulin-dependent kinases, myosin light chain kinase, Rho-kinase, two G-protein coupled receptor kinases (GRK2 and GRK6), various kinases in MAP kinase pathways, and cyclic-GMP-dependent kinases. Obviously, a large number of kinases were detected whose roles in the IMCD have not been investigated.

Relative to the number of serine/threonine kinases in IMCD, There are relatively few tyrosine kinases (Table 5B and 5C). Tyrosine kinases are of two types: non-receptor tyrosine kinases 
and receptor tyrosine kinases. Of the non-receptor tyrosine kinases, Frk (a src-family homolog) is strongly expressed in IMCD relative to non-IMCD elements. Also strongly represented is Janus kinase 1 (Jak1), which regulates transcription through activation of Stat1 and/or Stat2. Of the receptor tyrosine kinases, two are heavily expressed in the IMCD relative to non-IMCD elements, namely fibroblast growth factor receptor 2 (Fgfr2) and epidermal growth factor receptor (Egfr). Most of the detectable tyrosine kinases in the IMCD have been identified previously in fetal kidney including Jak1, Frk, Ptk2, Fgfr2, Egfr, Ryk, Ddr1 and Fgfr1 (36). Tyrosine kinases are associated with regulation of cell proliferation and differentiation.

\section{Protein phosphatases}

The serine/threonine phosphatases found in the IMCD are listed in Table 6A. Focusing on the catalytic subunits, the highest signal intensities in the IMCD appear to be the PP1 phosphatases of which three different isoforms are represented namely, $\alpha, \beta$ and $\gamma$. The catalytic subunit of calcineurin, a $\mathrm{Ca}^{2+}$-calmodulin dependent phosphatase (PPP3CA), is also expressed as is the catalytic subunit of the magnesium-dependent phosphatase, PP2C. For all of these catalytic subunits, significant expression was found in both the IMCD and non-IMCD fractions, consistent with their ubiquitous roles in cell signaling (69). In contrast, the PP2A catalytic subunit signal on the IMCD arrays was indistinguishable from background, although several of its regulatory subunits were present. Calcineurin has been reported to be expressed in the IMCD and to be colocalized with PKC $\zeta$, the RII subunit of PKA, and AQP2 in endosomes of the IMCD (35). It has been reported that the $\alpha$ isoform of the calcineurin catalytic subunit is required for normal intracellular trafficking of AQP2 (23). Finally, there are many more genes in the genome that code for Ser/Thr phosphatase regulatory subunits than for catalytic subunits, a number of which were found to be expressed in the IMCD.

Table 6B summarizes the protein tyrosine phosphatases (PTPs) found in the IMCD. The protein tyrosine phosphatases can be classified into transmembrane receptor-like protein tyrosine phosphatases and cytosolic protein tyrosine phosphatases (84). There are 16 PTP transcripts identified in the IMCD samples with signal intensity above median. Ten coded for cytosolic PTPs and 5 for transmembrane receptor-like PTPs.

Dual specificity phosphatases in the IMCD are summarized in Table 6C. These phosphatases dephosphorylate a phosphotyrosine and a neighboring phosphothreonine. Among these, the transcript corresponding to Dusp1 displays the strongest intensity in the IMCD. Its function is to dephosphorylate the MAP kinases ERK1 and ERK2 at the sites phosphorylated by dual specificity kinases (MAP kinase kinases or MEKs) (73). Two dual specificity phosphatases are expressed in the IMCD but not in non-IMCD cell types, namely Dusp2 and Dusp5.

\section{AKAPs}

A-kinase anchoring proteins (AKAPs) are scaffold proteins that facilitate localized signaling through creation of binding complexes that bring enzymes (mainly kinases and phosphatases) into the vicinity of their targets. Table 7 shows the AKAPs whose signal intensity in the IMCD samples were above background. Those expressed at highest levels were AKAP-7, -8, -9, -11 and -13. AKAP7 (aka AKAP188) has been shown to be colocalized with AQP2 intracellularly in the IMCD (27). Both AKAP7 and AQP2 were localized predominantly at the apical plasma membrane when the IMCD cells were stimulated with dDAVP.

\section{4-3-3 proteins}

14-3-3 proteins are phospho-serine/phospho-threonine binding proteins. By virtue of their binding specificities, they have been proposed to play various phosphorylation-dependent regulatory roles. There are seven isoforms of 14-3-3, viz. $\beta, \gamma, \varepsilon, \eta, \sigma, \tau$ and $\zeta$ (Note: $\alpha$ and $\delta$ are phosphorylated forms of $\beta$ and $\zeta$ isoforms (97;98)). In the present study, 5 of 7 isoforms of 
14-3-3 were identified in the IMCD with high signal intensity (Table 15). Functional roles of 14-3-3 in the IMCD have not been elucidated yet. However, 14-3-3 proteins have been found to modulate the function of the ubiquitin ligase Nedd4-2 in cultured collecting duct cells by binding to Nedd4-2 after sgk1-mediated phosphorylation (3).

\section{Phospholipases}

Table 8 shows the phospholipases in IMCD with signals above background for either IMCD or non-IMCD samples. Among the phospholipases with the highest signal intensities was cytosolic phospholipase A2 ( $\left.\mathrm{PLA}_{2}\right)$ which hydrolyzes the ester bond in SN-2 position of the core glycerol. This reaction is important because it liberates arachidonic acid, an unsaturated fatty acid that is the substrate for prostaglandin synthesis. Vasopressin has been seen to be variably associated with stimulation of prostaglandin E2 synthesis in collecting ducts, which provides a modulating influence on water permeability (68). Prostaglandin E2 synthesis depends on expression of one of two cyclooxygenases (COX-1 and COX-2). COX-1 exhibited a very high signal on the arrays, with a signal that is in the top 100 among transcripts in the IMCD. Both COX-1 and COX-2 are selectively expressed in the IMCD. As noted above, three different $\mathrm{PGE}_{2}$ receptors are expressed in the IMCD consistent with the view that $\mathrm{PGE}_{2}$ works as an autocoid.

As shown in Table 8, several isoforms of phospholipase C (PLC) are also expressed in the IMCD. PLC cleaves phosphatidylinositol 4,5-bisphosphate (PIP2) to yield two second messengers, diacylglycerol and inositol 1,4,5 tris-phosphate $\left(\mathrm{IP}_{3}\right)$. The beta isoforms are activated by heterotrimeric G-protein alpha subunits $\mathrm{G} \alpha_{\mathrm{q}}$ and $\mathrm{G} \alpha_{11}$. There are two PLC- $\beta$ isoforms expressed in the IMCD, PLC $\beta 1$ and PLC $\beta 4$. PLC $\beta 1$ is expressed selectively in IMCD cells versus non-IMCD cells. PLC $\gamma$ isoforms are regulated via tyrosine phosphorylation, typically following growth factor receptor activation (65). PLC $\gamma 1$, but not PLC $\gamma 2$, appears to be expressed in IMCD substantially above ackground. PLC 84 is also selectively expressed in the IMCD over non-IMCD cell types.

\section{Small GTP-binding proteins}

Table 9 lists transcripts corresponding to small GTP-binding proteins expressed on the IMCD arrays including Rab proteins, Arf/Sar proteins, Rho/Rac/CDC42 proteins, Ras and Ras-like proteins, and Ran proteins (77).

Members of the Rab family of proteins play a critical role in intracellular membrane trafficking. Large numbers of transcripts corresponding to Rab proteins were identified on the IMCD expression arrays (Table 9A) including many of those previously identified in a proteomic analysis of aquaporin-2-containing vesicles in IMCD cells (2). Most of the Rab proteins were found both in IMCD and non-IMCD cells, although Rab15 and Rab31 appear to be selectively expressed in the IMCD. Based on studies in non-renal cells, Rab15 is believed to be expressed in early endosomes and recycling endosomes (74). Rab31 is thought to be an early endosomal Rab based on its similarity to Rab5 (72).

ADP-ribosylation factors (Arfs) regulate coat protein-mediated vesicle budding, vesicular trafficking, and actin cytoskeleton assembly. Transcripts corresponding to most of the known Arf and Arl (ADP-ribosylation factor-like) proteins are expressed in the IMCD (Table 9B). Arf1 has been shown to be important for Golgi to ER transport. Arf6 is important for endocytosis $(10 ; 14)$. Both Arf1 and Arf6 displayed high signal intensity on the arrays. Transcripts for the Arf-like proteins Sarla and Sar1b were also found in the IMCD.

Rho/Rac/CDC42 GTPases are involved in regulation of the actin cytoskeleton and cell mobility. CDC42, Rnd1, Rac1, and RhoA are the four members of this family with the greatest 
signals on the arrays (Table 9C). In IMCD cells in primary culture, cAMP was found to inhibit Rho activation, thereby stimulating actin depolymerization and aiding translocation of aquaporin-2 to the plasma membrane (90). Rnd1 is expressed at a very high level in IMCD relative to other inner medullary cell types, specifically about 20 -fold higher. Rnd 1 has also been reported to promote disassembly of actin filaments (55). However, whether it plays a role in aquaporin-2 regulation has not yet been reported. A number of other Rho-like GTPases were also associated with high signal intensities in the IMCD including RhoB, RhoC, RhoG, RhoQ, RhoT2, and Rnd3.

The Ras-like protein family of small GTPases includes Rap, Rheb and Ral as well as Ras itself. They play an important role in regulating cell proliferation and differentiation. Among the Ras and Ras-like protein transcripts expressed in the IMCD, Rheb was associated with the greatest signal on the arrays (Table 9D). Rheb is a small GTPase that binds and activates the mTOR kinase (1). Another transcript with a relatively high signal intensity was K-Ras. This isoform of Ras has been shown to be an aldosterone-stimulated protein in collecting duct cells (93). Transcripts corresponding to other Ras-like proteins expressed in the IMCD include RalA, RalB, Rap1a, Rap1b, Rasd1, and Rras2. The Ral proteins have been found in aquaporin-2 containing intracellular vesicles in the IMCD (2). These proteins are associated with the socalled 'exocyst complex' involved in basolateral targeting of proteins. We have identified RalA in the basolateral plasma membrane of IMCD cells (unpublished data). Rap1 is involved in cell morphogenesis, cell differentiation, cell adhesion and cytoskeleton organization. It has been demonstrated that SPA-1 (signal-induced proliferation-associated 1), a GTPaseactivating protein specific to Rap1, binds to AQP2 in the renal medulla (56). We identified SPA-1 in the IMCD in this study (Supplementary Table S1). Studies in SPA-1 knockout mice showed a defect in AQP2 trafficking to the apical plasma membrane (58). Rap1 is also a target of Epac, a RapGEF, that is activated by cAMP. Epac has been found to be important for regulation of vasopressin-simulated calcium mobilization in collecting duct cells (101), which is necessary for AQP2 trafficking (13). Transcripts corresponding to Epac1 but not Epac2 were identified in the IMCD in our array studies (Supplementary Table S1). One of Rap1's targets is Raf1, a kinase in the MAP kinase pathway (see above). A full listing of transcripts corresponding to small GTP-binding protein GEFs, GAPs and interacting proteins found in the IMCD is reported in (Supplementary Table S4).

\section{SNARE proteins and SNARE-related proteins}

SNARE proteins play an important role in membrane fusion in eukaryotic cells. Syntaxin 7 and 12 were the SNARE protein transcripts with the greatest signals in the IMCD as shown in Table 10. Syntaxin 7 is present in the late endosome while syntaxin 12 is present in the recycling endosome (63), an organelle that may be important in AQP2 recycling to the plasma membrane. Plasma membrane syntaxins include syntaxins 2, 3 and 4 . Among these, only syntaxin 4 was associated with a strong signal in the IMCD. This syntaxin is present in the apical plasma membrane and has been proposed to be involved in AQP2 trafficking (47). In the current study, VAMP3 (cellubrevin) had the strongest signal intensity among VAMP/synaptobrevin transcripts. This protein was previously identified in the IMCD by immunogold electron microscopy (22). VAMP2 and VAMP4 transcripts were also found to be expressed in the IMCD above the median value. VAMP2 colocalizes with aquaporin-2 in AQP2-containing intracellular vesicles $(2 ; 54)$. An additional subfamily of SNARE proteins is the SNAP25 homologues. SNAP25 is neural-specific and its expression level was very low in the IMCD. SNAP23 protein has previously been identified in the IMCD on the basis of immunorecognition (32) and in the present study we found that it is expressed in the IMCD above the median expression level for all IMCD transcripts. 


\section{Clathrin and clathrin adaptors}

Both clathrin heavy chain and light chain polypeptides were identified in the IMCD (Table 11). The clathrin adaptors, AP1, AP2 and AP3 are also expressed in the IMCD. These clathrin adaptor proteins function in post-Golgi trafficking pathways. AP1 regulates vesicle transport between the trans-Golgi network and endosomes. AP2 regulates endocytosis (6) and AP3 is involved in vesicle trafficking from early endosomes to late endosomes or lysosomes (59). In addition, three clathrin adaptors called epsins are strongly expressed in the IMCD namely epsin 4 (enthoprotin), epsin 3 and epsin 2. These proteins bind both to ubiquitylated integral membrane proteins and to PIP2 (in addition to clathrin) and may be involved in regulated endocytosis of apical plasma membrane transporters in the collecting duct (94). Finally, an adaptor called phosphatidylinositol binding clathrin assembly protein or CALM, a PIP2binding clathrin adaptor was found at a relatively high signal intensity level on the IMCD arrays.

\section{Dynamin-like GTPases}

Dynamins are GTPases (although not 'small' GTPases) that are associated with clathrin-coated pits and are involved in the abscission process forming clathrin-coated vesicles. In this study, dynamin- 1 was expressed below background and dynamin-2 and -3 were expressed at very low levels only ( 0.21 and 0.45 , respectively, Table 15$)$. In contrast, the dynamin-like GTPases Mx1 and Mx2 were associated with high signal intensities in the IMCD (7.60 and 16.14, respectively). Their locations and roles in the IMCD cell have not been reported.

\section{Actin and actin-binding proteins}

$\gamma$ - and $\beta$-actin, the two chief forms of non-muscle actin were associated with the highest actin signals on the IMCD arrays. These forms have been seen previously in proteomic studies of the IMCD $(2 ; 62)$. Vasopressin induces actin filament depolymerization in the IMCD (70), a process that has been shown to be required for AQP2 translocation from intracelluar to apical plasma membrane in cultured CD8 cells (79).

ERM proteins (ezrin, radixin, and moesin) are actin-binding proteins that link actin to the plasma membrane and are involved in signal transduction and cytoskeleton remodeling (85). In the present study, ezrin (Vil2) and radixin (Rdx) were found to be expressed in IMCD at high signal intensity. On the contrary, moesin mRNA was not detected. A previous study (66) reported a marked increased in the expression of ezrin mRNA in the inner medullas of lithium-treated rats, which was associated with an increase in ezrin protein in the IMCD. The authors proposed that this protein plays a role in the nephrogenic diabetes insipidus seen in response to lithium. Moesin has been reported to mediate trafficking of AQP2 to plasma membrane in rabbit CD8 cells (79). Our finding of low or nonexistent levels of moesin mRNA in the IMCD suggests that moesin's role in AQP2 trafficking may not be universal.

Several actin-binding proteins have been identified that are AQP2-binding partners in rat inner medulla including $\alpha 2$-spectrin, $\alpha$-tropomyosin $5 b$ (tropomyosin $3 \gamma$ ), gelsolin, and $\alpha$-actinin (57) Transcripts corresponding to all of these proteins showed high signal intensity on our microarrays.

\section{Myosins}

Myosin regulatory light chain B and non-muscle myosin II-B (heavy chain 10) were associated with the greatest signals among myosin gene products. Also associated with relatively high signals in IMCD were myosin II-A (heavy chain 9) and unconventional myosins 1B, 1C, 1D, and $1 \mathrm{E}$, as well as myosin 5B. Myosin regulatory light chain has been demonstrated to be phosphorylated in the IMCD in response to vasopressin (12). This protein regulates the non- 
muscle myosins II-A and II-B, both of which are expressed in the IMCD. As demonstrated previously, myosin II-B is collecting duct selective in the inner medulla (12). Myosin II-A has been demonstrated to be bound to AQP2 in cell lysates of kidney inner medulla (57). Recently myosin 5B has been reported to be associated with Rab11-positive AQP2-containing endosomes, presumably recycling endosomes (52).

\section{Microtubules and microtubule-associated proteins}

Table $12 \mathrm{C}$ shows the transcripts corresponding to the microtubule proteins and microtubuleassociated proteins including molecular motors that are expressed above background on the arrays. Microtubule disruption with colchicine and other agents reduces the hydro-osmotic action of vasopressin in collecting ducts (61) through effects on AQP2 trafficking (67). In addition, it has been shown that both dyneins (microtubule-based molecular motors) and dynactin in the inner medulla were associated with trafficking of AQP2-containing vesicles to the apical plasma membrane (49). In the present study, multiple dynein and dynactin isoforms were found in the rat IMCD. Cytoplasmic dyneins are multi-subunit proteins consisting of a combination of light chains, heavy chains, and intermediate chains. The predominant dyneins in the IMCD are cytoplasmic dyneins with signal intensity of light chain-1 > intermediate chain- $1>$ heavy chain-2 polypeptides. Cytoplasmic dynein heavy polypeptide- 2 is selectively expressed in IMCD over non-IMCD elements of the inner medulla.

\section{Transporters and channels}

The transcripts corresponding to transport proteins found in the IMCD above background are reported in Table 13. As can be seen in Table 13A, three water channels are associated with extremely high signal intensities, namely AQP4, AQP2 and AQP3. The signal intensities for these aquaporins were ranked 3rd, 10th and 14th, respectively, among the 7913 annotated transcripts found in the IMCD. In contrast, AQP1 was present only in the non-IMCD samples from the inner medulla.

Table 13B shows the ion channels and transporters expressed in the IMCD. The chloride channel ClC-Kb is expressed in the basolateral plasma membrane of cells throughout the distal nephron from thick ascending limb to the collecting duct and is mutated in some forms of Bartter's Syndrome (92). Its transcript was found at a moderate level in IMCD but not in nonIMCD components of the inner medulla. Note that the levels of the epithelial sodium channel $(\mathrm{ENaC}) \alpha, \beta$, and $\gamma$ transcripts are relatively low, consistent with the low level of $\mathrm{ENaC}$ protein expressed in this segment (24).

Table 13C shows the non-mitochondrial solute carrier (SLC) transcripts found in the IMCD. Among these, the transcript with the highest signal was the vasopressin-regulated urea transporter UT-A (Slc14a2). This protein is key to the accumulation of urea in the renal inner medulla $(19 ; 20)$. Its manner of regulation by vasopressin is controversial with one group claiming that the protein undergoes regulated trafficking (39) while another finds an absence of regulated trafficking by vasopressin (33).

Supplementary Table S6 reports the mitochondrial transporters and carriers detected. As may be expected, many of these were components of the F0-F1 ATP synthase responsible for proton gradient-driven ATP synthesis.

\section{Transcription factors}

We identified about 824 transcription factors expressed in IMCD above background. A list of the transcription factors identified with signal intensity above median is shown in Supplementary Table S7. Only a few of these have been studied in the context of AQP2 regulation. 
The $5^{\prime}$ flanking region of AQP2 has been sequenced and putative transcription factor binding sites have been identified including AP1, AP2, CRE, GATA, and Sp1 motifs in human, mouse and rat $(64 ; 88)$.

\section{Leucine zipper transcription factors including CREB-like factors}

Long-term increases in ambient vasopressin in animals or cultured cells results in increased AQP2 protein abundance that is mediated at least in part by enhanced AQP2 gene transcription rates (53). A cAMP responsive element (CRE) plays a critical role $(31 ; 50 ; 100)$. It has been widely assumed that regulation of $\mathrm{AQP} 2$ transcription involves the transcription factor CREB. However, in this study, we found that CREB itself (now called Creb1) is associated with an extremely low signal intensity on the arrays (Table 14A). This finding raises the possibility that other CREB-family members may be responsible for the long-term regulation of AQP2 gene transcription. The CREB-like transcriptional factors in the IMCD associated with high signal intensities are Atf3 and Atf4 (Creb2). All of these factors share the same recognition site TGACGTCA, which is present in the AQP2 promoter region. Atf 3 is thought to be a stressresponse transcription factor (25). We hypothesize that Atf4 (Creb2) mediates the effects of cAMP on AQP2 gene expression.

Previous studies have demonstrated that Fos expression is markedly increased in rat inner medulla in response to vasopressin (7). Furthermore, c-Jun phosphorylation was found to be increased in the same study. These two proteins together constitute the transcription factor AP1. They were both found on our arrays with very high signal intensity (Table 14A)

\section{Zinc finger transcription factors}

Kruppel-like factors (KLF) are transcription factors in the zinc finger family that regulate cell differentiation, cell proliferation and development with a DNA-binding site motif of CACCC $(34 ; 86)$. KLF12 was found to be expressed in the IMCDs of young mouse kidneys (76). In the current study in mature rats, the KLF12 intensity on the arrays was, however, below background. Other KLF transcription factors are expressed in the IMCD including KLF5, KLF6, KLF9, and KLF10.

Rat GATA3 but not GATA2 can be amplified by RT-PCR from the collecting ducts of rat kidneys (89). Overexpression of rat GATA3 in primary culture of mouse OMCD cells can increase AQP2 activities, indicating that GATA3 could interact with GATA motifs in the AQP-2 promoter (89). Also, both GATA2 and GATA3 were detected at high signal intensity in the IMCD, but not in the non-IMCD portions of the inner medulla (Table 14B). GATA1 signal intensity was below background. Sp1 is also a member of the KLF transcription factor family. In the present study, Sp1 showed a moderate signal intensity in the IMCD.

\section{Rel/Dorsal transcription factors}

TonEBP (Nfat5) is a Rel/Dorsal transcription factor that regulates cellular accumulation of organic osmolytes and HSP70. These mechanisms are critical to the process that protects cells from the hypertonic stress of the renal medulla. In the present study, TonEBP was indeed found to be expressed in the IMCD at a transcript level, although, the signal intensity was below the median on the arrays (Supplementary Table S1). Mice deficient in the TonEBP gene display severe atrophy of the renal medulla, presumably because the cells failed to adapt to the hyperosmolality (44). In response to long term hypertonicity in mpkCCD cells, TonEBP mediates expression of UT-A and possibly AQP2 independent of vasopressin level (26). However, AQP2 was not found to be strongly regulated by local osmolality in the renal inner medulla (82). 


\section{Acknowledgements}

We thank Tony Cooper, Nalini Raghavachari for help with the Affymetrix array hybridization and data reporting, Guozhong Ma for setting up the online database, and Peter Munson and Xiuli Xu for advice regarding normalization of array data. This study was funded by the Intramural Budget of the National Heart, Lung, and Blood Institute (Project HL001285, M.A. Knepper, principal investigator).

GRANTS

None

\section{References}

1. Avruch J, Hara K, Lin Y, Liu M, Long X, Ortiz-Vega S, Yonezawa K. Insulin and amino-acid regulation of mTOR signaling and kinase activity through the Rheb GTPase. Oncogene 2006;25:6361-6372. [PubMed: 17041622]

2. Barile M, Pisitkun T, Yu MJ, Chou CL, Verbalis MJ, Shen RF, Knepper MA. Large scale protein identification in intracellular aquaporin-2 vesicles from renal inner medullary collecting duct. Mol Cell Proteomics 2005;4:1095-1106. [PubMed: 15905145]

3. Bhalla V, Daidie D, Li H, Pao AC, LaGrange LP, Wang J, Vandewalle A, Stockand JD, Staub O, Pearce D. Serum- and glucocorticoid-regulated kinase 1 regulates ubiquitin ligase neural precursor cell-expressed, developmentally down-regulated protein 4-2 by inducing interaction with 14-3-3. Mol Endocrinol 2005;19:3073-3084. [PubMed: 16099816]

4. Bouley R, Pastor-Soler N, Cohen O, McLaughlin M, Breton S, Brown D. Stimulation of AQP2 membrane insertion in renal epithelial cells in vitro and in vivo by the cGMP phosphodiesterase inhibitor sildenafil citrate (Viagra). Am J Physiol Renal Physiol 2005;288:F1103-F1112. [PubMed: 15644488]

5. Breyer MD, Breyer RM. G protein-coupled prostanoid receptors and the kidney. Annual Review of Physiology 2001;63:579-605.

6. Brodsky FM, Chen CY, Knuehl C, Towler MC, Wakeham DE. Biological baseket weaving: formation and function of clathrin-coated vesicles. Annual Review of Cell and Developmental Biology 2001;17:517-568.

7. Brooks HL, Ageloff S, Kwon TH, Brandt W, Terris JM, Seth A, Michea L, Nielsen S, Fenton R, Knepper MA. cDNA array identification of genes regulated in rat renal medulla in response to vasopressin infusion. Am J Physiol Renal Physiol 2003;284:F218-F228. [PubMed: 12388413]

8. Cai Q, Keck M, McReynolds MR, Klein JD, Greer K, Sharma K, Hoying JB, Sands JM, Brooks HL. Effects of water restriction on gene expression in mouse renal medulla: identification of 3betaHSD4 as a collecting duct protein. Am J Physiol Renal Physiol 2006;291:F218-F224. [PubMed: 16478974]

9. Chabardes-Garonne D, Mejean A, Aude JC, Cheval L, Di Stefano A, Gaillard MC, Imbert-Teboul M, Wittner M, Balian C, Anthouard V, Robert C, Segurens B, Wincker P, Weissenbach J, Doucet A, Elalouf JM. A panoramic view of gene expression in the human kidney. PNAS 2003;100:1371013715. [PubMed: 14595018]

10. Chavrier P, Goud B. The role of ARF and Rab GTPases in membrane transport. Current Opinion in Cell Biology 1999;11:466-475. [PubMed: 10449335]

11. Chen, Sy; Bhargava, A.; Mastroberardino, L.; Meijer, OC.; Wang, J.; Buse, P.; Firestone, GL.; Verrey, F.; Pearce, D. Epithelial sodium channel regulated by aldosterone-induced protein sgk. PNAS 1999;96:2514-2519. [PubMed: 10051674]

12. Chou CL, Christensen BM, Frische S, Vorum H, Desai RA, Hoffert JD, de LP, Nielsen S, Knepper MA. Non-muscle myosin II and myosin light chain kinase are downstream targets for vasopressin signaling in the renal collecting duct. J Biol Chem 2004;19;279:49026-49035. [PubMed: 15347643]

13. Chou CL, Yip KP, Michea L, Kador K, Ferraris JD, Wade JB, Knepper MA. Regulation of aquaporin-2 trafficking by vasopressin in the renal collecting duct. Roles of ryanodine-sensitive $\mathrm{Ca}^{2+}$ stores and calmodulin. J Biol Chem 2000;275:36839-36846. [PubMed: 10973964]

14. Donaldson JG. Multiple Roles for Arf6: Sorting, Structuring, and Signaling at the Plasma Membrane. J Biol Chem 2003;278:41573-41576. [PubMed: 12912991] 
15. Dousa TP. Cyclic-3',5'-nucleotide phosphodiesterase isozymes in cell biology and pathophysiology of the kidney. Kidney Int 1999;55:29-62. [PubMed: 9893113]

16. Ecelbarger CA, Chou CL, Lolait SJ, Knepper MA, DiGiovanni SR. Evidence for dual signaling pathways for V2 vasopressin receptor in rat inner medullary collecting duct. Am J Physiol Renal Physiol 1996;270:F623-F633.

17. Ecelbarger CA, Maeda Y, Gibson CC, Knepper MA. Extracellular ATP increases intracellular calcium in rat terminal collecting duct via a nucleotide receptor. Am J Physiol Renal Physiol 1994;267:F998-1006.

18. Edwards RM, Spielman WS. Adenosine A1 receptor-mediated inhibition of vasopressin action in inner medullary collecting duct. Am J Physiol Renal Physiol 1994;266:F791-F796.

19. Fenton RA, Chou CL, Stewart GS, Smith CP, Knepper MA. Urinary concentrating defect in mice with selective deletion of phloretin-sensitive urea transporters in the renal collecting duct. Proc Natl Acad Sci U S A 2004;101:7469-7474. [PubMed: 15123796]

20. Fenton RA, Flynn A, Shodeinde A, Smith CP, Schnermann J, Knepper MA. Renal phenotype of UTA urea transporter knockout mice. J Am Soc Nephrol 2005;16:1583-1592. [PubMed: 15829709]

21. Fenton RA, Knepper MA. Urea and renal function in the 21st century: insights from knockout mice. J Am Soc Nephrol. 2007

22. Franki N, Macaluso F, Schubert W, Gunther L, Hays RM. Water channel-carrying vesicles in the rat IMCD contain cellubrevin. Am J Physiol 1995;269:C797-C801. [PubMed: 7573412]

23. Gooch JL, Toro JJ, Guler RL, Barnes JL. Calcineurin A-alpha but not A-beta is required for normal kidney development and function. Am J Pathol 2004;165:1755-1765. [PubMed: 15509543]

24. Hager H, Kwon TH, Vinnikova AK, Masilamani S, Brooks HL, Frokiaer J, Knepper MA, Nielsen S. Immunocytochemical and immunoelectron microscopic localization of alpha-, beta-, and gammaENaC in rat kidney. Am J Physiol Renal Physiol 2001;280:F1093-F1106. [PubMed: 11352848]

25. Hai T, Wolfgang CD, Marsee DK, Allen AE, Sivaprasad U. ATF3 and stress responses. Gene Expr 1999;7:321-335. [PubMed: 10440233]

26. Hasler U, Jeon US, Kim JA, Mordasini D, Kwon HM, Feraille E, Martin PY. Tonicity-responsive enhancer binding protein is an essential regulator of aquaporin-2 expression in renal collecting duct principal cells. J Am Soc Nephrol 2006;17:1521-1531. [PubMed: 16641150]

27. Henn V, Edemir B, Stefan E, Wiesner B, Lorenz D, Theilig F, Schmitt R, Vossebein L, Tamma G, Beyermann M, Krause E, Herberg FW, Valenti G, Bachmann S, Rosenthal W, Klussmann E. Identification of a novel A-kinase anchoring protein 18 isoform and evidence for its role in the vasopressin-induced aquaporin-2 shuttle in renal principal cells. J Biol Chem 2004;279:2665426665. [PubMed: 15037626]

28. Hoffert JD, Chou CL, Fenton RA, Knepper MA. Calmodulin is required for vasopressin-stimulated increase in cyclic AMP production in inner medullary collecting duct. J Biol Chem 2005;280:1362413630. [PubMed: 15710610]

29. Hoffert JD, van Balkom BW, Chou CL, Knepper MA. Application of difference gel electrophoresis to the identification of inner medullary collecting duct proteins. Am J Physiol Renal Physiol 2004;286:F170-F179. [PubMed: 12965894]

30. Hoorn EJ, Hoffert JD, Knepper MA. Combined proteomics and pathways analysis of collecting duct reveals a protein regulatory network activated in vasopressin escape. J Am Soc Nephrol 2005;16:2852-2863. [PubMed: 16079266]

31. Hozawa S, Holtzman EJ, Ausiello DA. cAMP motifs regulating transcription in the aquaporin 2 gene. Am J Physiol Cell Physiol 1996;270:C1695-C1702.

32. Inoue T, Nielsen S, Mandon B, Terris J, Kishore BK, Knepper MA. SNAP-23 in rat kidney: colocalization with aquaporin-2 in collecting duct vesicles. Am J Physiol 1998;275:F752-F760. [PubMed: 9815132]

33. Inoue T, Terris J, Ecelbarger CA, Chou CL, Nielsen S, Knepper MA. Vasopressin regulates apical targeting of aquaporin-2 but not of UT1 urea transporter in renal collecting duct. Am J Physiol 1999;276:F559-F566. [PubMed: 10198415]

34. Iuchi S. Three classes of $\mathrm{C}_{2} \mathrm{H}_{2}$ zinc finger proteins. Cellular and Molecular Life Sciences (CMLS) 2001;58:625-635. [PubMed: 11361095] 
35. Jo I, Ward DT, Baum MA, Scott JD, Coghlan VM, Hammond TG, Harris HW. AQP2 is a substrate for endogenous PP2B activity within an inner medullary AKAP-signaling complex. Am J Physiol Renal Physiol 2001;281:F958-F965. [PubMed: 11592953]

36. Kee N, McTavish AJ, Papillon J, Cybulsky AV. Receptor protein tyrosine kinases in perinatal developing rat kidney. Kidney Int 1997;52:309-317. [PubMed: 9263985]

37. Kishore BK, Chou CL, Knepper MA. Extracellular nucleotide receptor inhibits AVP-stimulated water permeability in inner medullary collecting duct. Am J Physiol Renal Physiol 1995;269:F863-F869.

38. Kishore BK, Ginns SM, Krane CM, Nielsen S, Knepper MA. Cellular localization of P2Y2 purinoceptor in rat renal inner medulla and lung. Am J Physiol Renal Physiol 2000;278:F43-F51. [PubMed: 10644654]

39. Klein JD, Frohlich O, Blount MA, Martin CF, Smith TD, Sands JM. Vasopressin increases plasma membrane accumulation of urea transporter UT-A1 in rat inner medullary collecting ducts. J Am Soc Nephrol 2006;17:2680-2686. [PubMed: 16959825]

40. Knepper MA, Danielson RA, Saidel GM, Post RS. Quantitative analysis of renal medullary anatomy in rats and rabbits. Kidney Int 1977;12:313-323. [PubMed: 604620]

41. Knepper MA, Masilamani S. Targeted proteomics in the kidney using ensembles of antibodies. Acta Physiol Scand 2001;173:11-21. [PubMed: 11678722]

42. Kohan DE, Hughes AK, Perkins SL. Characterization of endothelin receptors in the inner medullary collecting duct of the rat. J Biol Chem 1992;267:12336-12340. [PubMed: 1318315]

43. Kozasa T, Jiang X, Hart MJ, Sternweis PM, Singer WD, Gilman AG, Bollag G, Sternweis PC. p115 RhoGEF, a GTPase activating protein for G alpha12 and G alpha 13. Science 1998;280:2109-2111. [PubMed: 9641915]

44. Lam AKM, Ko BCB, Tam S, Morris R, Yang JY, Chung SK, Chung SSM. Osmotic Response Element-binding Protein (OREBP) is an essential regulator of the urine concentrating mechanism. $\mathrm{J}$ Biol Chem 2004;279:48048-48054. [PubMed: 15347663]

45. Maeda Y, Han JS, Gibson CC, Knepper MA. Vasopressin and oxytocin receptors coupled to $\mathrm{Ca}^{2+}$ mobilization in rat inner medullary collecting duct. Am J Physiol Renal Physiol 1993;265:F15-F25.

46. Maeda Y, Terada Y, Nonoguchi H, Knepper MA. Hormone and autacoid regulation of cAMP production in rat IMCD subsegments. Am J Physiol Renal Physiol 1992;263:F319-F327.

47. Mandon B, Chou CL, Nielsen S, Knepper MA. Syntaxin-4 is localized to the apical plasma membrane of rat renal collecting duct cells: possible role in aquaporin-2 trafficking. J Clin Invest 1996;98:906913. [PubMed: 8770861]

48. Manning G, Whyte DB, Martinez R, Hunter T, Sudarsanam S. The protein kinase complement of the human genome. Science 2002;298:1912-1934. [PubMed: 12471243]

49. Marples D, Schroer TA, Ahrens N, Taylor A, Knepper MA, Nielsen S. Dynein and dynactin colocalize with AQP2 water channels in intracellular vesicles from kidney collecting duct. Am J Physiol Renal Physiol 1998;274:F384-F394.

50. Matsumura Y, Uchida S, Rai T, Sasaki S, Marumo F. Transcriptional regulation of aquaporin-2 water channel gene by cAMP. J Am Soc Nephrol 1997;8:861-867. [PubMed: 9189851]

51. McReynolds MR, Taylor-Garcia KM, Greer KA, Hoying JB, Brooks HL. Renal medullary gene expression in aquaporin-1 null mice. Am J Physiol Renal Physiol 2005;288:F315-F321. [PubMed: 15507545]

52. Nedvetsky PI, Stefan E, Frische S, Santamaria K, Wiesner B, Valenti G, Hammer JA III, Nielsen S, Goldenring JR, Rosenthal W, Klussmann E. A role of myosin Vb and Rab11-FIP2 in the aquaporin-2 shuttle. Traffic 2007;8:110-123. [PubMed: 17156409]

53. Nielsen S, Frokiaer J, Marples D, Kwon TH, Agre P, Knepper MA. Aquaporins in the kidney: from molecules to medicine. Physiol Rev 2002;82:205-244. [PubMed: 11773613]

54. Nielsen S, Marples D, Birn H, Mohtashami M, Dalby NO, Trimble M, Knepper M. Expression of VAMP-2-like protein in kidney collecting duct intracellular vesicles. Colocalization with Aquaporin-2 water channels. J Clin Invest 1995;96:1834-1844. [PubMed: 7560075]

55. Nobes CD, Lauritzen I, Mattei MG, Paris S, Hall A, Chardin P. A new member of the Rho family, Rnd1, promotes disassembly of actin filament structures and loss of cell adhesion. J Cell Biol 1998;141:187-197. [PubMed: 9531558] 
56. Noda Y, Horikawa S, Furukawa T, Hirai K, Katayama Y, Asai T, Kuwahara M, Katagiri K, Kinashi T, Hattori M, Minato N, Sasaki S. Aquaporin-2 trafficking is regulated by PDZ-domain containing protein SPA-1. FEBS Lett 2004;568:139-145. [PubMed: 15196935]

57. Noda Y, Horikawa S, Katayama Y, Sasaki S. Identification of a multiprotein “motor" complex binding to water channel aquaporin-2. Biochem Biophys Res Commun 2005;20;330:1041-1047. [PubMed: 15823548]

58. Noda Y, Sasaki S. Regulation of aquaporin-2 trafficking and its binding protein complex. Biochimica et Biophysica Acta (BBA) - Biomembranes 2006;1758:1117-1125.

59. Ohno H. Physiological roles of clathrin adaptor AP complexes: lessons from mutant animals. J Biochem (Tokyo) 2006;139:943-948. [PubMed: 16788044]

60. Oishi R, Nonoguchi H, Tomita K, Marumo F. Endothelin-1 inhibits AVP-stimulated osmotic water permeability in rat inner medullary collecting duct. Am J Physiol Renal Physiol 1991;261:F951F956.

61. Phillips ME, Taylor A. Effect of nocodazole on the water permeability response to vasopressin in rabbit collecting tubules perfused in vitro. J Physiol 1989;411:529-544. [PubMed: 2559198]

62. Pisitkun T, Bieniek J, Tchapyjnikov D, Wang G, Wu WW, Shen RF, Knepper MA. High-throughput identification of IMCD proteins using LC-MS/MS. Physiol Genomics 2006;25:263-276. [PubMed: 16449382]

63. Prekeris R, Klumperman J, Chen YA, Scheller RH. Syntaxin 13 mediates cycling of plasma membrane proteins via tubulovesicular recycling endosomes. J Cell Biol 1998;143:957-971. [PubMed: 9817754]

64. Rai T, Uchida S, Marumo F, Sasaki S. Cloning of rat and mouse aquaporin-2 gene promoters and identification of a negative cis-regulatory element. Am J Physiol Renal Physiol 1997;273:F264F273.

65. Rhee SG. Regulation of phosphoinositide-specific phospholipase C. Annual Review of Biochemistry 2001;70:281-312.

66. Rojek A, Nielsen J, Brooks HL, Gong H, Kim YH, Kwon TH, Frokiaer J, Nielsen S. Altered expression of selected genes in kidney of rats with lithium-induced NDI. Am J Physiol Renal Physiol 2005;288:F1276-F1289. [PubMed: 15687245]

67. Sabolic I, Katsura T, Verbavatz JM, Brown D. The AQP2 water channel: effect of vasopressin treatment, microtubule disruption, and distribution in neonatal rats. J Membr Biol 1995;143:165175. [PubMed: 7539496]

68. Schlondorff D. Renal prostaglandin synthesis. Sites of production and specific actions of prostaglandins. Am J Med 1986;81:1-11. [PubMed: 3529950]

69. Sim AT, Baldwin ML, Rostas JA, Holst J, Ludowyke RI. The role of serine/threonine protein phosphatases in exocytosis. Biochem J 2003;373:641-659. [PubMed: 12749763]

70. Simon H, Gao Y, Franki N, Hays RM. Vasopressin depolymerizes apical F-actin in rat inner medullary collecting duct. Am J Physiol 1993;265:C757-C762. [PubMed: 8214031]

71. Simons BL, Wang G, Shen RF, Knepper MA. In vacuo isotope coded alkylation technique (IVICAT); an N-terminal stable isotopic label for quantitative liquid chromatography/mass spectrometry proteomics. Rapid Commun Mass Spectrom 2006;20:2463-2477. [PubMed: 16862635]

72. Simpson JC, Jones AT. Early endocytic Rabs: functional prediction to functional characterization. Biochem Soc Symp 2005:99-108. [PubMed: 15649134]

73. Slack DN, Seternes OM, Gabrielsen M, Keyse SM. Distinct binding determinants for Erk2/p38alpha and JNK MAP kinases mediate catalytic activation and substrate selectivity of MAP kinase phosphatase-1. J Biol Chem 2001;276:16491-16500. [PubMed: 11278799]

74. Somsel Rodman J, Wandinger-Ness A. Rab GTPases coordinate endocytosis. J Cell Sci 2000;113:183-192. [PubMed: 10633070]

75. Stefan E, Wiesner B, Baillie GS, Mollajew R, Henn V, Lorenz D, Furkert J, Santamaria K, Nedvetsky P, Hundsrucker C, Beyermann M, Krause E, Pohl P, Gall I, Macintyre AN, Bachmann S, Houslay MD, Rosenthal W, Klussmann E. Compartmentalization of cAMP-dependent signaling by phosphodiesterase-4D is involved in the regulation of vasopressin-mediated water reabsorption in renal principal cells. J Am Soc Nephrol 2007;18:199-212. [PubMed: 17135396] 
76. Suda S, Rai T, Sohara E, Sasaki S, Uchida S. Postnatal expression of KLF12 in the inner medullary collecting ducts of kidney and its trans-activation of UT-A1 urea transporter promoter. Biochemical and Biophysical Research Communications 2006;344:246-252. [PubMed: 16615998]

77. Takai Y, Sasaki T, Matozaki T. Small GTP-binding proteins. Physiol Rev 2001;81:153-208. [PubMed: 11152757]

78. Takenaka M, Imai E, Nagasawa Y, Matsuoka Y, Moriyama T, Kaneko T, Hori M, Kawamoto S, Okubo K. Gene expression profiles of the collecting duct in the mouse renal inner medulla. Kidney Int 2000;57:19-24. [PubMed: 10620183]

79. Tamma G, Klussmann E, Maric K, Aktories K, Svelto M, Rosenthal W, Valenti G. Rho inhibits cAMP-induced translocation of aquaporin-2 into the apical membrane of renal cells. Am J Physiol Renal Physiol 2001;281:F1092-F1101. [PubMed: 11704560]

80. Tamura K, Ono A, Miyagishima T, Nagao T, Urushidani T. Comparison of gene expression profiles among papilla, medulla and cortex in rat kidney. J Toxicol Sci 2006;31:449-469. [PubMed: 17202760]

81. Terada Y, Tomita K, Nonoguchi H, Marumo F. Different localization of two types of endothelin receptor mRNA in microdissected rat nephron segments using reverse transcription and polymerase chain reaction assay. J Clin Invest 1992;90:107-112. [PubMed: 1321837]

82. Terris J, Ecelbarger CA, Nielsen S, Knepper MA. Long-term regulation of four renal aquaporins in rats. Am J Physiol 1996;271:F414-F422. [PubMed: 8770174]

83. Thomas PD, Campbell MJ, Kejariwal A, Mi H, Karlak B, Daverman R, Diemer K, Muruganujan A, Narechania A. PANTHER: a library of protein families and subfamilies indexed by function. Genome Res 2003;13:2129-2141. [PubMed: 12952881]

84. Tonks NK. Protein tyrosine phosphatases: from genes, to function, to disease. Nat Rev Mol Cell Biol 2006;7:833-846. [PubMed: 17057753]

85. Tsukita S, Yonemura S. Cortical actin organization: lessons from ERM (Ezrin/Radixin/Moesin) proteins. J Biol Chem 1999;274:34507-34510. [PubMed: 10574907]

86. Turner J, Crossley M. Mammalian Kruppel-like transcription factors: more than just a pretty finger. Trends in Biochemical Sciences 1999;24:236-240. [PubMed: 10366853]

87. Twigger S, Lu J, Shimoyama M, Chen D, Pasko D, Long H, Ginster J, Chen CF, Nigam R, Kwitek A, Eppig J, Maltais L, Maglott D, Schuler G, Jacob H, Tonellato PJ. Rat Genome Database (RGD): mapping disease onto the genome. Nucl Acids Res 2002;30:125-128. [PubMed: 11752273]

88. Uchida S, Sasaki S, Fushimi K, Marumo F. Isolation of human aquaporin-CD gene. J Biol Chem 1994;269:23451-23455. [PubMed: 7522228]

89. Uchida S, Matsumura Y, Rai T, Sasaki S, Marumo F. Regulation of aquaporin-2 gene transcription by GATA-3. Biochemical and Biophysical Research Communications 1997;232:65-68. [PubMed: 9125153]

90. Valenti G, Procino G, Tamma G, Carmosino M, Svelto M. Minireview: aquaporin 2 trafficking. Endocrinology 2005;146:5063-5070. [PubMed: 16150901]

91. van Balkom BW, Hoffert JD, Chou CL, Knepper MA. Proteomic analysis of long-term vasopressin action in the inner medullary collecting duct of the Brattleboro rat. Am J Physiol Renal Physiol 2004;286:F216-F224. [PubMed: 14532164]

92. Vandewalle A, Cluzeaud F, Bens M, Kieferle S, Steinmeyer K, Jentsch TJ. Localization and induction by dehydration of $\mathrm{ClC}-\mathrm{K}$ chloride channels in the rat kidney. Am J Physiol Renal Physiol 1997;272:F678-F688.

93. Verrey F, Loffing J, Zecevic M, Heitzmann D, Staub O. SGK1: aldosterone-induced relay of $\mathrm{Na}^{+}$ transport regulation in distal kidney nephron cells. Cell Physiol Biochem 2003;13:21-28. [PubMed: 12649599]

94. Wang H, Traub LM, Weixel KM, Hawryluk MJ, Shah N, Edinger RS, Perry CJ, Kester L, Butterworth MB, Peters KW, Kleyman TR, Frizzell RA, Johnson JP. Clathrin-mediated endocytosis of the epithelial sodium channel. Role of epsin. J Biol Chem 2006;19;281:14129-14135. [PubMed: 16574660]

95. Wilson FH, Kahle KT, Sabath E, Lalioti MD, Rapson AK, Hoover RS, Hebert SC, Gamba G, Lifton RP. Molecular pathogenesis of inherited hypertension with hyperkalemia: The Na-Cl cotransporter is inhibited by wild-type but not mutant WNK4. PNAS 2003;100:680-684. [PubMed: 12515852] 
96. Wu F, Park F, Cowley AW Jr, Mattson DL. Quantification of nitric oxide synthase activity in microdissected segments of the rat kidney. Am J Physiol Renal Physiol 1999;276:F874-F881.

97. Yaffe MB, Elia AEH. Phosphoserine/threonine-binding domains. Current Opinion in Cell Biology 2001;13:131-138. [PubMed: 11248545]

98. Yaffe MB, Rittinger K, Volinia S, Caron PR, Aitken A, Leffers H, Gamblin SJ, Smerdon SJ, Cantley LC. The structural basis for 14-3-3:phosphopeptide binding specificity. Cell 1997;91:961-971. [PubMed: 9428519]

99. Yang CL, Angell J, Mitchell R, Ellison DH. WNK kinases regulate thiazide-sensitive Na-Cl cotransport. J Clin Invest 2003;111:1039-1045. [PubMed: 12671053]

100. Yasui M, Zelenin SM, Celsi G, Aperia A. Adenylate cyclase-coupled vasopressin receptor activates AQP2 promoter via a dual effect on CRE and AP1 elements. Am J Physiol Renal Physiol 1997;272:F443-F450.

101. Yip KP. Epac-mediated $\mathrm{Ca}^{2+}$ mobilization and exocytosis in inner medullary collecting duct. Am J Physiol Renal Physiol 2006;291:F882-F890. [PubMed: 16684923]

102. Yu MJ, Pisitkun T, Wang G, Shen RF, Knepper MA. LC-MS/MS analysis of apical and basolateral plasma membranes of rat renal collecting duct cells. Mol Cell Proteomics 2006;5:2131-2145. [PubMed: 16899541] 


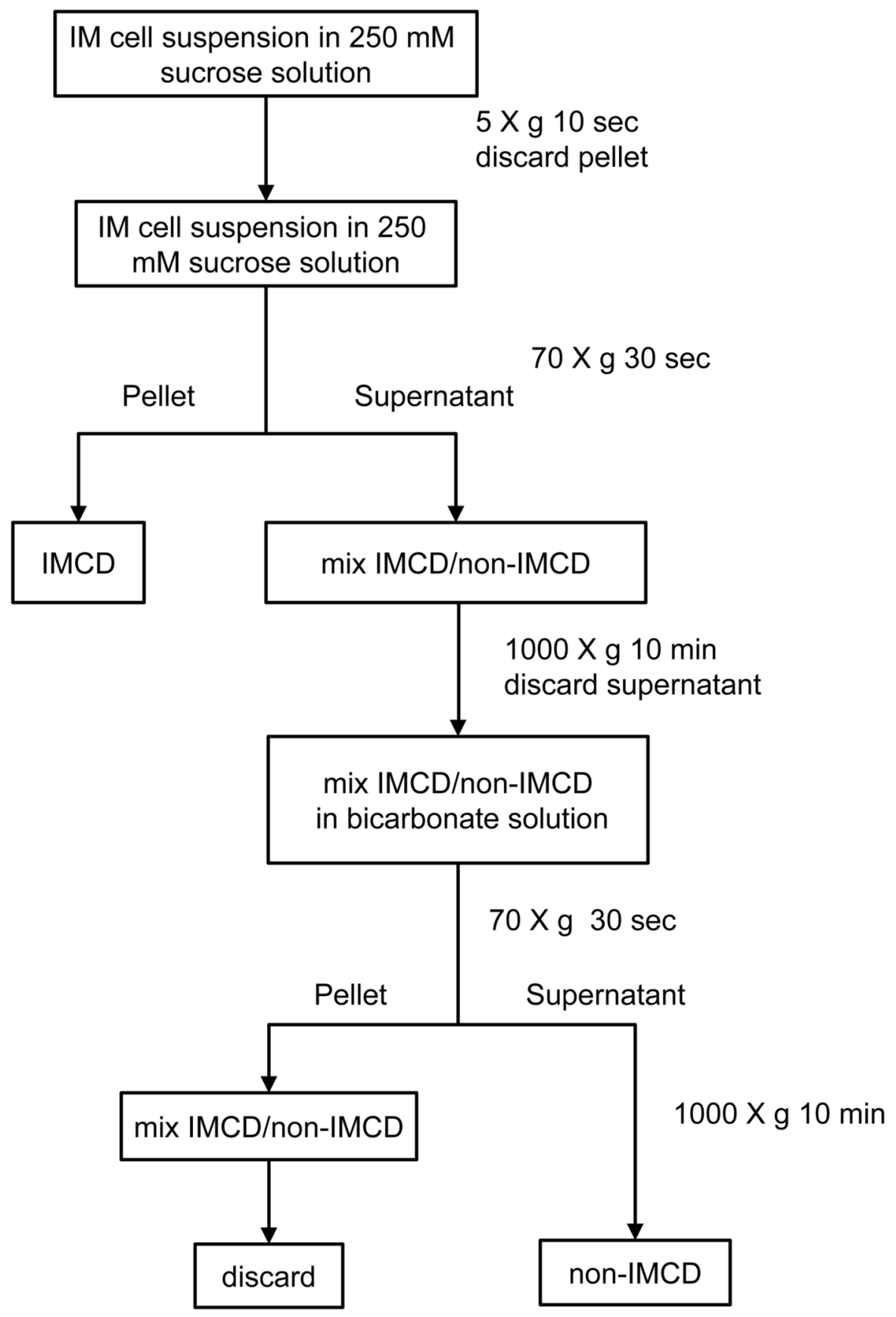

Figure 1.

Isolation scheme for rat IMCD and non-IMCD cell fractions. 
A)

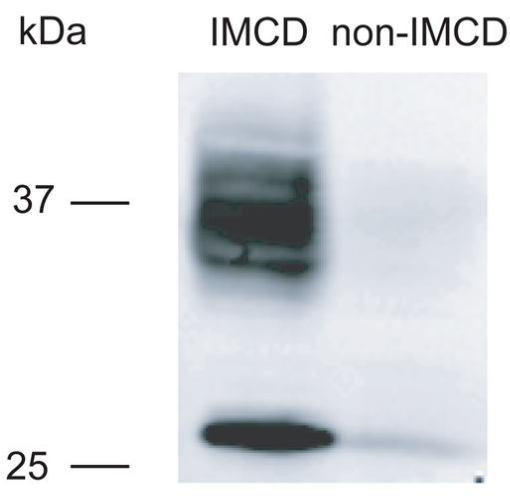

Aquaporin 2

B)

kDa IMCD non-IMCD

$37-$

25

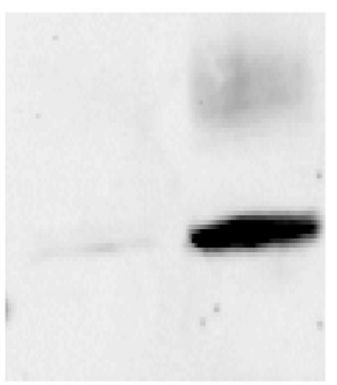

Aquaporin 1

C)

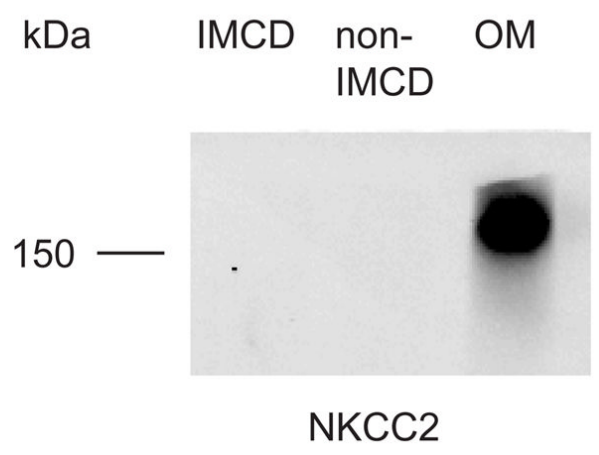

Figure 2.

Immunoblots illustrating purity of fractions. A. Immunoblot of IMCD and non-IMCD fractions probed with aquaporin-2 (AQP2) antibody, $10 \mu 1 /$ lane. B: immunoblot probed with aquaporin-1 (AQP1) antibody, $10 \mu \mathrm{l}$ protein loaded/lane. C: Immunoblot probed with NKCC2 antibody, $10 \mu \mathrm{l}$ protein loaded/lane. Protein concentrations in samples were: IMCD, $1.25 \mu \mathrm{g} / \mu \mathrm{l}$, nonIMCD, $1.1 \mu \mathrm{g} / \mu \mathrm{l}$. OMCD, $0.8 \mu \mathrm{g} / \mu \mathrm{l}$. 
G-protein coupled receptors.

Table 1

\begin{tabular}{|c|c|c|c|}
\hline Gene Name & Gene Symbol & $\begin{array}{c}\text { IMCD-Signal } \\
\text { Mean } \pm \text { SE }\end{array}$ & $\begin{array}{l}\text { non-IMCD-Signal } \\
\text { Mean } \pm \text { SE }\end{array}$ \\
\hline chemokine orphan receptor 1 & Cmkor1 & $17.40 \pm 1.13$ & $1.55 \pm 0.33$ \\
\hline arginine vasopressin receptor 2 & Avpr2 & $14.20 \pm 0.34$ & $-1.89 \pm 0.22$ \\
\hline $\begin{array}{l}\text { endothelial differentiation, lysophosphatidic acid G-protein- } \\
\text { coupled receptor, } 2\end{array}$ & Edg2 & $8.74 \pm 0.31$ & $3.73 \pm 0.43$ \\
\hline frizzled homolog 1 (Drosophila) & Fzd1 & $8.62 \pm 0.13$ & $-0.87 \pm 0.24$ \\
\hline thrombin receptor & $\mathrm{F} 2 \mathrm{r}$ & $7.42 \pm 0.14$ & $4.80 \pm 0.45$ \\
\hline prostaglandin $\mathrm{E}$ receptor 1 (subtype EP1) & Ptger1 & $6.78 \pm 0.27$ & $-1.27 \pm 0.17$ \\
\hline progestin and adipoQ receptor family member $\mathrm{V}$ & Paqr5 & $6.69 \pm 0.19$ & $2.83 \pm 0.09$ \\
\hline taste receptor, type 1 , member 2 & Tas1r2 & $5.10 \pm 0.21$ & $1.62 \pm 0.16$ \\
\hline endothelin receptor type B & Ednrb & $4.74 \pm 0.21$ & $7.58 \pm 0.75$ \\
\hline$\gamma$-aminobutyric acid B receptor 1 & Gabbr1 & $3.80 \pm 0.30$ & $-0.96 \pm 0.12$ \\
\hline adenosine $\mathrm{A} 1$ receptor & Adora1 & $3.50 \pm 0.05$ & $0.64 \pm 0.10$ \\
\hline cadherin EGF LAG seven-pass G-type receptor 2 & Celsr2 & $2.66 \pm 0.17$ & $2.99 \pm 0.15$ \\
\hline leucine-rich repeat-containing $\mathrm{G}$ protein-coupled receptor 4 & Lgr4 & $2.28 \pm 0.31$ & $1.01 \pm 0.14$ \\
\hline adrenergic receptor, alpha $2 \mathrm{a}$ & Adra2a & $2.26 \pm 0.12$ & $-0.23 \pm 0.12$ \\
\hline $\mathrm{G}$ protein-coupled receptor, family $\mathrm{C}$, group 5 , member A & Gprc5a & $2.18 \pm 0.25$ & $5.93 \pm 0.35$ \\
\hline lanC-like 1 & Lancl1 & $1.64 \pm 0.07$ & $2.46 \pm 0.52$ \\
\hline $\mathrm{G}$ protein-coupled receptor, family $\mathrm{C}$, group 5 , member $\mathrm{C}$ & Gprc5c & $1.44 \pm 0.08$ & $1.42 \pm 0.13$ \\
\hline frizzled homolog 6 (Drosophila) & Fzd6 & $1.36 \pm 0.13$ & $1.15 \pm 0.07$ \\
\hline latrophilin 2 & Lphn2 & $1.35 \pm 0.17$ & $0.74 \pm 0.12$ \\
\hline cadherin EGF LAG seven-pass G-type receptor 1 & Celsr1 & $1.18 \pm 0.07$ & $0.93 \pm 0.13$ \\
\hline $\mathrm{G}$ protein-coupled receptor 116 & Gpr116 & $1.13 \pm 0.34$ & $6.77 \pm 0.43$ \\
\hline prostaglandin E receptor 4 (subtype EP4) & Ptger4 & $1.09 \pm 0.21$ & $3.54 \pm 0.23$ \\
\hline purinergic receptor P2Y, G-protein coupled 2 & P2ry2 & $0.90 \pm 0.03$ & $2.81 \pm 0.20$ \\
\hline adrenergic receptor, alpha $1 \mathrm{~d}$ & Adrald & $0.90 \pm 0.06$ & $-0.28 \pm 0.03$ \\
\hline thrombin receptor-like 1 & F2rl1 & $0.89 \pm 0.02$ & $0.70 \pm 0.07$ \\
\hline frizzled homolog 4 (Drosophila) & Fzd4 & $0.85 \pm 0.08$ & $0.38 \pm 0.16$ \\
\hline G protein-coupled receptor 37 & Gpr37 & $0.69 \pm 0.07$ & $-0.11 \pm 0.04$ \\
\hline $\mathrm{G}$ protein-coupled receptor 176 & Gpr176 & $0.48 \pm 0.10$ & $0.47 \pm 0.02$ \\
\hline frizzled homolog 3 (Drosophila) & Fzd3 & $0.37 \pm 0.04$ & $0.14 \pm 0.03$ \\
\hline purinergic receptor P2Y, G-protein coupled, 14 & P2ry14 & $0.36 \pm 0.06$ & $2.37 \pm 0.17$ \\
\hline adrenomedullin receptor & Admr & $0.30 \pm 0.05$ & $0.91 \pm 0.24$ \\
\hline G protein-coupled receptor 64 & Gpr64 & $0.27 \pm 0.02$ & $0.74 \pm 0.07$ \\
\hline angiotensin receptor-like 1 & Agtrl1 & $0.25 \pm 0.01$ & $0.51 \pm 0.11$ \\
\hline $\mathrm{G}$ protein-coupled receptor 37 -like 1 & Gpr3711 & $0.23 \pm 0.05$ & $0.18 \pm 0.07$ \\
\hline $\begin{array}{l}\text { G protein-coupled receptor kinase 2, groucho gene related } \\
\text { (Drosophila) }\end{array}$ & Gprk2l & $0.22 \pm 0.01$ & $0.31 \pm 0.02$ \\
\hline $\mathrm{G}$ protein-coupled receptor 19 & Gpr19 & $0.20 \pm 0.04$ & $0.27 \pm 0.07$ \\
\hline calcium-sensing receptor like 1 & Casrl1 & $0.18 \pm 0.03$ & $0.16 \pm 0.03$ \\
\hline 5-hydroxytryptamine (serotonin) receptor $2 \mathrm{~A}$ & Htr2a & $0.17 \pm 0.02$ & $0.20 \pm 0.04$ \\
\hline $\begin{array}{l}\text { endothelial differentiation, sphingolipid G-protein-coupled } \\
\text { receptor, } 5\end{array}$ & Edg5 & $0.16 \pm 0.02$ & $0.38 \pm 0.01$ \\
\hline cholinergic receptor, muscarinic 3 & Chrm3 & $0.15 \pm 0.03$ & $0.37 \pm 0.04$ \\
\hline parathyroid hormone receptor 1 & Pthr1 & $0.14 \pm 0.05$ & $0.18 \pm 0.05$ \\
\hline adenosine $\mathrm{A} 2 \mathrm{~B}$ receptor & Adora2b & $0.14 \pm 0.03$ & $0.17 \pm 0.01$ \\
\hline endothelin receptor type A & Ednra & $0.14 \pm 0.01$ & $0.21 \pm 0.03$ \\
\hline prostaglandin E receptor 3 (subtype EP3) & Ptger3 & $0.12 \pm 0.04$ & $0.44 \pm 0.05$ \\
\hline growth hormone releasing hormone receptor & Ghrhr & $0.11 \pm 0.0$ & $0.45 \pm 0.05$ \\
\hline latrophilin 1 & Lphn1 & $0.10 \pm 0.03$ & $0.20 \pm 0.01$ \\
\hline luteinizing hormone/choriogonadotropin receptor & Lhegr & $0.07 \pm 0.03$ & $0.27 \pm 0.06$ \\
\hline calcitonin receptor-like & Calcrl & $0.07 \pm 0.01$ & $0.43 \pm 0.10$ \\
\hline galanin receptor 2 & Galr2 & $0.06 \pm 0.01$ & $0.38 \pm 0.02$ \\
\hline adrenergic receptor, beta 2 & Adrb2 & $0.05 \pm 0.01$ & $0.19 \pm 0.02$ \\
\hline chemokine (C-C motif) receptor 5 & Ccr5 & $0.03 \pm 0.03$ & $0.49 \pm 0.07$ \\
\hline EGF, latrophilin and seven transmembrane domain containing 1 & Eltd1 & $0.03 \pm 0.03$ & $5.65 \pm 0.17$ \\
\hline smoothened homolog (Drosophila) & Smo & $0.02 \pm 0.03$ & $0.48 \pm 0.04$ \\
\hline chemokine (C-X-C motif) receptor 3 & Cxcr3 & $-0.02 \pm 0.04$ & $0.54 \pm 0.03$ \\
\hline thrombin receptor-like 2 & F2r12 & $-0.04 \pm 0.01$ & $0.46 \pm 0.03$ \\
\hline G protein-coupled receptor 109A & Gpr109a & $-0.05 \pm 0.01$ & $0.68 \pm 0.03$ \\
\hline purinergic receptor $\mathrm{P} 2 \mathrm{Y}, \mathrm{G}$-protein coupled, 13 & P2ry13 & $-0.06 \pm 0.01$ & $0.55 \pm 0.06$ \\
\hline prostaglandin E receptor 2 (subtype EP2) & Ptger2 & $-0.06 \pm 0.01$ & $0.37 \pm 0.02$ \\
\hline complement component $3 \mathrm{a}$ receptor 1 & C3arl & $-0.09 \pm 0.01$ & $0.71 \pm 0.05$ \\
\hline platelet-activating factor receptor & Ptafr & $-0.10 \pm 0.06$ & $3.47 \pm 0.32$ \\
\hline neuropeptide $\mathrm{Y}$ & Npy & $-0.17 \pm 0.01$ & $1.88 \pm 0.33$ \\
\hline CD97 antigen & Cd97 & $-0.27 \pm 0.03$ & $2.51 \pm 0.20$ \\
\hline pyrimidinergic receptor $\mathrm{P} 2 \mathrm{Y}$, G-protein coupled, 6 & P2ry6 & $-0.39 \pm 0.05$ & $2.14 \pm 0.09$ \\
\hline arginine vasopressin receptor $1 \mathrm{~A}$ & Avpr1a & $-0.59 \pm 0.02$ & $4.33 \pm 0.18$ \\
\hline chemokine (C-X-C motif) receptor 4 & Cxcr4 & $-0.84 \pm 0.01$ & $4.18 \pm 0.13$ \\
\hline complement component 5 , receptor 1 & C5r1 & $-0.90 \pm 0.03$ & $4.15 \pm 0.24$ \\
\hline endothelial differentiation sphingolipid G-protein-coupled & Edg1 & $-1.07 \pm 0.17$ & $16.70 \pm 1.39$ \\
\hline
\end{tabular}




\begin{tabular}{llcc}
\hline Gene Name & Gene Symbol & $\begin{array}{c}\text { IMCD-Signal } \\
\text { Mean } \pm \text { SE }\end{array}$ & $\begin{array}{c}\text { non-IMCD-Signal } \\
\text { Mean } \pm \text { SE }\end{array}$ \\
\hline $\begin{array}{l}\text { EGF-like module containing, mucin-like, hormone receptor-like } \\
\text { sequence 1 }\end{array}$ & Emr1 & $-1.60 \pm 0.05$ & $6.91 \pm 0.63$ \\
\hline
\end{tabular}


Table 2

Heterotrimeric G-proteins.

\begin{tabular}{llcc}
\hline Gene Name & Gene Symbol & IMCD-Signal Mean \pm SE & $\begin{array}{c}\text { non-IMCD-Signal Mean } \\
\pm \text { SE }\end{array}$ \\
& & & $22.86 \pm 00.42$ \\
GNAS complex locus & Gnas & $34.30 \pm 01.16$ & $8.60 \pm 0.41$ \\
gamma 5 subunit & Gn55 & $11.34 \pm 0.26$ & $6.54 \pm 0.41$ \\
beta polypeptide 2 & Gnb2 & $8.81 \pm 0.12$ & $3.41 \pm 0.29$ \\
beta 1 & Gnb1 & $8.01 \pm 0.35$ & $1.98 \pm 0.14$ \\
transducin (beta)-like 1X-linked & Tb11xr1_predicted & $6.49 \pm 0.14$ & $5.04 \pm 0.75$ \\
receptor 1 (predicted) & & & $0.67 \pm 0.23$ \\
gamma 10 & Gng10 & $5.79 \pm 0.23$ & $1.62 \pm 0.05$ \\
alpha inhibiting 3 & Gnai3 & $3.20 \pm 0.05$ & $1.88 \pm 0.18$ \\
similar to RIKEN cDNA 5730596K20 & RGD1309871_predicted & $2.04 \pm 0.12$ & $0.22 \pm 0.05$ \\
(predicted) & & & $6.03 \pm 1.07$ \\
alpha q polypeptide & Gnaq & $1.92 \pm 0.11$ & $1.34 \pm 0.20$ \\
beta 5 & Gnb5 & $1.85 \pm 0.02$ & $0.49 \pm 0.13$ \\
alpha inhibiting 2 & Gnai2 & $1.39 \pm 0.21$ & $5.57 \pm 0.46$ \\
alpha inhibiting 1 & Gnai1 & $1.31 \pm 0.03$ & $0.77 \pm 0.05$ \\
alpha 12 & Gna12 & $0.55 \pm 0.08$ & \\
similar to hypothetical protein & RGD1310180 & & \\
FLJ12681 & & & \\
& & & \\
\hline
\end{tabular}


Table 3

Nucleotide cyclases.

\begin{tabular}{|c|c|c|c|}
\hline Gene Name & Gene Symbol & IMCD-Signal Mean \pm SE & $\begin{array}{c}\text { non-IMCD- Signal Mean } \pm \\
\text { SE }\end{array}$ \\
\hline $\begin{array}{l}\text { adenylate cyclase } 6 \\
\text { guanylate cyclase } 1 \text {, soluble, beta } 3 \\
\text { adenylate cyclase } 3 \\
\text { adenylate cyclase } 9 \text { (predicted) } \\
\text { guanylate cyclase } 2 \mathrm{~g} \\
\text { natriuretic peptide receptor } 2 \\
\text { CD } 38 \text { antigen } \\
\text { natriuretic peptide receptor } 1 \\
\text { adenylate cyclase } 4 \\
\text { adenylate cyclase } 2 \\
\text { bone marrow stromal cell antigen } 1\end{array}$ & $\begin{array}{l}\text { Adcy6 } \\
\text { Gucy1b3 } \\
\text { Adcy3 } \\
\text { Adcy9_predicted } \\
\text { Gucy2g } \\
\text { Npr2 } \\
\text { Cd38 } \\
\text { Npr1 } \\
\text { Adcy4 } \\
\text { Adcy2 } \\
\text { Bst1 }\end{array}$ & $\begin{array}{r}7.98 \pm 0.02 \\
1.95 \pm 0.04 \\
1.21 \pm 0.21 \\
0.66 \pm 0.02 \\
0.08 \pm 0.03 \\
0.03 \pm 0.06 \\
0.02 \pm 0.04 \\
-0.01 \pm 0.03 \\
-0.03 \pm 0.03 \\
-0.04 \pm 0.02 \\
-2.02 \pm 0.09\end{array}$ & $\begin{array}{c}3.26 \pm 0.63 \\
2.03 \pm 0.22 \\
0.29 \pm 0.11 \\
0.77 \pm 0.07 \\
1.27 \pm 0.16 \\
0.89 \pm 0.08 \\
0.49 \pm 0.06 \\
1.60 \pm 0.14 \\
2.03 \pm 0.14 \\
0.62 \pm 0.07 \\
10.08 \pm 0.82\end{array}$ \\
\hline
\end{tabular}


Table 4

Phosphodiesterases.

\begin{tabular}{llc}
\hline Gene Name & Gene Symbol & $\begin{array}{c}\text { IMCD-Signal Mean } \pm \\
\text { SE }\end{array}$ \\
& & $\begin{array}{c}\text { non-IMCD-Signal Mean } \\
\pm \text { SE }\end{array}$ \\
\hline phosphodiesterase 4C, cAMP-specific & Dpde1 & $9.97 \pm 0.21$ \\
phosphodiesterase 1A, calmodulin-dependent & Pde1a & $4.33 \pm 0.09$ \\
phosphodiesterase 4B, cAMP specific & Pde4b & $1.95 \pm 0.25$ \\
cyclic nucleotide phosphodiesterase 1 & Cnp1 & $1.87 \pm 0.04$ \\
phosphodiesterase 4A, cAMP specific & Pde4a & $1.23 \pm 0.03$ \\
phosphodiesterase 3B & Pde3b & $0.96 \pm 0.14$ \\
phosphodiesterase 7B & Pde7b & $0.83 \pm 0.03$ \\
phosphodiesterase 8A & Pde8a & $0.66 \pm 0.07$ \\
phosphodiesterase 2A, cGMP-stimulated & Pde2a & $0.52 \pm 0.01$ \\
phosphodiesterase 1C & Pde1c & $0.17 \pm 0.02$ \\
phosphodiesterase 4D, cAMP specific & Pde4d & $0.11 \pm 0.03$ \\
phosphodiesterase 7A & Pde7a & $-0.09 \pm 0.13$ \\
& & $0.136 \pm 0.06$ \\
\hline
\end{tabular}




\section{Protein kinases}

Table 5

Table 5A. Serine/threonine kinases with IMCD signals above median.

Table 5B. Non-receptor tyrosine kinases with IMCD signals above median.

Table 5C. Tyrosine kinase receptors with IMCD signals above median.

\begin{tabular}{|c|c|c|c|}
\hline Gene Name & Gene Symbol & $\begin{array}{c}\text { IMCD-Signal } \\
\text { Mean } \pm \text { SE }\end{array}$ & $\begin{array}{c}\text { non-IMCD-Signal } \\
\text { Mean } \pm \text { SE }\end{array}$ \\
\hline serum/glucocorticoid regulated kinase & Sgk1 & $34.33 \pm 0.30$ & $8.30 \pm 0.71$ \\
\hline transglutaminase $2, \mathrm{C}$ polypeptide & Tgm2 & $18.36 \pm 0.19$ & $4.36 \pm 0.44$ \\
\hline receptor-interacting serine-threonine kinase 4 (predicted) & Ripk4_predicted & $13.71 \pm 0.09$ & $0.81 \pm 0.15$ \\
\hline casein kinase 1 , alpha 1 & Csnkla1 & $12.81 \pm 0.68$ & $4.67 \pm 0.63$ \\
\hline CDC-like kinase 1 & Clk1 & $12.76 \pm 0.16$ & $5.39 \pm 0.20$ \\
\hline mitogen-activated protein kinase 6 & Mapk6 & $12.73 \pm 0.71$ & $-0.39 \pm 0.51$ \\
\hline wee 1 homolog (S. pombe) & Wee1 & $11.25 \pm 0.86$ & $-1.83 \pm 0.30$ \\
\hline CDP-diacylglycerol synthase 1 & Cds1 & $10.28 \pm 0.44$ & $1.48 \pm 0.11$ \\
\hline receptor-interacting serine-threonine kinase 3 & Ripk3 & $9.99 \pm 0.17$ & $7.15 \pm 0.62$ \\
\hline polo-like kinase 2 (Drosophila) & Plk2 & $8.95 \pm 0.56$ & $2.75 \pm 0.28$ \\
\hline protein kinase, cAMP dependent, catalytic, beta (predicted) & Prkacb_predicted & $7.53 \pm 0.22$ & $4.14 \pm 0.17$ \\
\hline homeodomain interacting protein kinase 1 (predicted) & Hipk1_predicted & $6.66 \pm 0.09$ & $4.07 \pm 0.27$ \\
\hline protein kinase $\mathrm{C}$, iota & Prkci & $6.45 \pm 0.16$ & $7.42 \pm 0.17$ \\
\hline large tumor suppressor 2 (predicted) & Lats2_predicted & $5.71 \pm 0.25$ & $9.07 \pm 0.56$ \\
\hline protein kinase $\mathrm{C}$, zeta & Prkcz & $5.43 \pm 0.07$ & $0.25 \pm 0.12$ \\
\hline PCTAIRE-motif protein kinase 2 & Pctk2 & $5.40 \pm 0.17$ & $2.58 \pm 0.10$ \\
\hline integrin linked kinase & $\mathrm{Ilk}$ & $5.35 \pm 0.34$ & $6.82 \pm 0.40$ \\
\hline dystrophia myotonica-protein kinase (predicted) & Dmpk_predicted & $5.21 \pm 0.45$ & $3.0 \pm 0.31$ \\
\hline eukaryotic translation initiation factor 2 alpha kinase 1 & Eif2ak1 & $5.14 \pm 0.23$ & $1.58 \pm 0.30$ \\
\hline MAP/microtubule affinity-regulating kinase 3 & Mark3 & $4.71 \pm 0.05$ & $3.34 \pm 0.15$ \\
\hline v-raf-1 murine leukemia viral oncogene homolog 1 & Raf1 & $4.69 \pm 0.10$ & $3.35 \pm 0.05$ \\
\hline calcium/calmodulin-dependent protein kinase II, delta & Camk2d & $4.68 \pm 0.23$ & $4.05 \pm 0.16$ \\
\hline mitogen activated protein kinase 3 & Mapk3 & $4.68 \pm 0.30$ & $2.76 \pm 0.37$ \\
\hline protein kinase, cGMP-dependent, type 1 (mapped) & Prkg1_mapped & $4.64 \pm 0.25$ & $3.36 \pm 0.28$ \\
\hline WNK lysine deficient protein kinase 4 & Wnk4 & $4.45 \pm 0.16$ & $2.51 \pm 0.72$ \\
\hline casein kinase II, alpha 1 polypeptide & Csnk2a1 & $4.02 \pm 0.06$ & $3.83 \pm 0.09$ \\
\hline protein kinase $\mathrm{N} 2$ & Pkn2 & $4.02 \pm 0.18$ & $2.23 \pm 0.08$ \\
\hline MAP kinase-activated protein kinase 2 & Mapkapk2 & $4.01 \pm 0.07$ & $3.68 \pm 0.09$ \\
\hline cyclin $\mathrm{G}$ associated kinase & Gak & $3.98 \pm 0.14$ & $2.51 \pm 0.17$ \\
\hline doublecortin and CaM kinase-like 3 (predicted) & Dcamk13_predicted & $3.86 \pm 0.19$ & $0.30 \pm 0.02$ \\
\hline thymoma viral proto-oncogene 1 & Akt1 & $3.81 \pm 0.06$ & $3.32 \pm 0.12$ \\
\hline CDC42 binding protein kinase beta & $\mathrm{Cdc} 42 \mathrm{bpb}$ & $3.69 \pm 0.07$ & $0.70 \pm 0.23$ \\
\hline conserved helix-loop-helix ubiquitous kinase (predicted) & Chuk_predicted & $3.64 \pm 0.09$ & $3.36 \pm 0.19$ \\
\hline protein kinase $\mathrm{N} 1$ & $\mathrm{Pkn} 1$ & $3.56 \pm 0.59$ & $-0.58 \pm 0.25$ \\
\hline phosphorylase kinase, gamma 2 (testis) & Phkg2 & $3.48 \pm 0.14$ & $2.40 \pm 0.05$ \\
\hline cyclin-dependent kinase 4 & Cdk4 & $3.26 \pm 0.10$ & $3.17 \pm 0.13$ \\
\hline PCTAIRE-motif protein kinase 3 & Pctk3 & $3.25 \pm 0.26$ & $-0.35 \pm 0.14$ \\
\hline mitogen activated protein kinase 14 & Mapk14 & $3.18 \pm 0.05$ & $4.35 \pm 0.29$ \\
\hline casein kinase 1 , delta & Csnk1d & $3.15 \pm 0.10$ & $1.46 \pm 0.24$ \\
\hline serine/arginine-rich protein specific kinase 2 (predicted) & Srpk2_predicted & $3.07 \pm 0.06$ & $1.17 \pm 0.07$ \\
\hline myosin, light polypeptide kinase (predicted) & Mylk_predicted & $3.01 \pm 0.16$ & $2.10 \pm 0.06$ \\
\hline serine/threonine kinase 3 (STE20 homolog, yeast) & Stk3 & $3.01 \pm 0.18$ & $2.20 \pm 0.25$ \\
\hline NUAK family, SNF1-like kinase, 2 & Nuak2 & $2.99 \pm 0.15$ & $1.60 \pm 0.50$ \\
\hline protein kinase, $\mathrm{X}$-linked & Prkx & $2.89 \pm 0.21$ & $1.24 \pm 0.11$ \\
\hline MAP/microtubule affinity-regulating kinase 2 & Mark2 & $2.72 \pm 0.02$ & $2.66 \pm 0.20$ \\
\hline receptor (TNFRSF)-interacting serine-threonine kinase 2 & Ripk2 & $2.59 \pm 0.08$ & $0.83 \pm 0.07$ \\
\hline Rho-associated coiled-coil forming kinase 1 & Rock1 & $2.59 \pm 0.02$ & $3.85 \pm 0.29$ \\
\hline death-associated protein kinase 3 & Dapk3 & $2.52 \pm 0.07$ & $1.85 \pm 0.13$ \\
\hline protein kinase, lysine deficient 1 & Prkwnk1 & $2.47 \pm 0.25$ & $7.39 \pm 0.51$ \\
\hline unc-51-like kinase 1 (mapped) & Ulk1_mapped & $2.46 \pm 0.08$ & $2.23 \pm 0.26$ \\
\hline leucine-rich repeat kinase 1 (predicted) & Lrrk1_predicted & $2.44 \pm 0.19$ & $2.88 \pm 0.15$ \\
\hline CDC like kinase 4 & $\mathrm{Clk} 4$ & $2.41 \pm 0.19$ & $2.88 \pm 0.10$ \\
\hline protein kinase $C$, nu & Prken & $2.41 \pm 0.22$ & $2.96 \pm 0.16$ \\
\hline mitogen activated protein kinase kinase kinase 12 & Map3k12 & $2.37 \pm 0.26$ & $2.17 \pm 0.27$ \\
\hline $\begin{array}{l}\text { receptor (TNFRSF)-interacting serine-threonine kinase } 1 \\
\text { (predicted) }\end{array}$ & Ripk1_predicted & $2.22 \pm 0.06$ & $0.85 \pm 0.18$ \\
\hline tousled-like kinase 1 (predicted) & Tlk1_predicted & $1.98 \pm 0.05$ & $1.49 \pm 0.20$ \\
\hline mitogen activated protein kinase kinase kinase 7 (predicted) & Map3k7_predicted & $1.90 \pm 0.04$ & $1.70 \pm 0.14$ \\
\hline vaccinia related kinase 3 & Vrk3 & $1.87 \pm 0.04$ & $1.31 \pm 0.23$ \\
\hline V-raf murine sarcoma 3611 viral oncogene homolog & Araf & $1.86 \pm 0.05$ & $1.51 \pm 0.14$ \\
\hline Fms interacting protein & Fmip & $1.82 \pm 0.18$ & $1.63 \pm 0.21$ \\
\hline MAP kinase-interacting serine/threonine kinase 2 & Mknk2 & $1.76 \pm 0.03$ & $2.22 \pm 0.17$ \\
\hline cyclin-dependent kinase 9 (CDC2-related kinase) & Cdk9 & $1.70 \pm 0.08$ & $2.27 \pm 0.06$ \\
\hline PCTAIRE-motif protein kinase 1 & Pctk1 & $1.64 \pm 0.08$ & $1.36 \pm 0.27$ \\
\hline thymoma viral proto-oncogene 2 & Akt2 & $1.63 \pm 0.01$ & $0.91 \pm 0.15$ \\
\hline casein kinase 1 , gamma 2 & Csnk1g2 & $1.61 \pm 0.02$ & $2.57 \pm 0.19$ \\
\hline serine/threonine kinase 16 & Stk16 & $1.60 \pm 0.04$ & $1.54 \pm 0.08$ \\
\hline
\end{tabular}




\begin{tabular}{|c|c|c|c|}
\hline Gene Name & Gene Symbol & $\begin{array}{l}\text { IMCD-Signal } \\
\text { Mean } \pm \text { SE }\end{array}$ & $\begin{array}{c}\text { non-IMCD-Signal } \\
\text { Mean } \pm \text { SE }\end{array}$ \\
\hline $\begin{array}{l}\text { similar to TANK-binding kinase } 1 \\
\text { serine/threonine kinase } 38 \\
\text { casein kinase II, alpha 2, polypeptide (predicted) } \\
\text { protein kinase, interferon-inducible double stranded RNA } \\
\text { dependent } \\
\text { G protein-coupled receptor kinase } 6 \\
\text { FK506 binding protein 12-rapamycin associated protein } 1 \\
\text { protein kinase C, delta } \\
\text { PRP4 pre-mRNA processing factor } 4 \text { homolog B (yeast) } \\
\text { serine/threonine kinase } 17 b \text { (apoptosis-inducing) } \\
\text { tousled-like kinase } 2 \text { (Arabidopsis) (predicted) } \\
\text { intestinal cell kinase } \\
\text { cyclin-dependent kinase } 7 \text { (homolog of Xenopus MO15 cdk- } \\
\text { activating kinase) } \\
\text { protein kinase, DNA activated, catalytic polypeptide } \\
\text { (predicted) } \\
\text { microtubule associated serine/threonine kinase } 2 \text { (predicted) } \\
\text { similar to CDC-like kinase } 2 \\
\text { RIO kinase } 3 \text { (yeast) (predicted) } \\
\text { similar to nemo like kinase (predicted) } \\
\text { SNF1-like kinase } \\
\text { eukaryotic translation initiation factor } 2 \text { alpha kinase } 3 \\
\text { G protein-coupled receptor kinase } 2 \text {, groucho gene related } \\
\text { (Drosophila) } \\
\text { calcium/calmodulin-dependent protein kinase I } \\
\text { cyclin-dependent kinase (CDC2-like) } 10 \\
\text { mitogen activated protein kinase } 13 \\
\text { mitogen activated protein kinase } 1 \\
\text { mitogen-activated protein kinase-activated protein kinase } 3 \\
\text { cyclin-dependent kinase } 5 \\
\text { protein kinase C, epsilon } \\
\text { G protein-coupled receptor kinase } 5\end{array}$ & $\begin{array}{l}\text { LOC299827 } \\
\text { Stk38 } \\
\text { Csnk2a2_predicted } \\
\text { Prkr } \\
\text { Gprk6 } \\
\text { Frap1 } \\
\text { Prkcd } \\
\text { Prpf4b } \\
\text { Stk17b } \\
\text { Tlk2_predicted } \\
\text { Ick } \\
\text { Cdk7 } \\
\text { Prkdc_predicted } \\
\text { Mast2_predicted } \\
\text { LOC365842 } \\
\text { Riok3_predicted } \\
\text { LOC365949 } \\
\text { Snf1lk } \\
\text { Eif2ak3 } \\
\text { Gprk21 } \\
\text { Camk1 } \\
\text { Cdk10 } \\
\text { Mapk13 } \\
\text { Mapk1 } \\
\text { Mapkapk3 } \\
\text { Cdk5 } \\
\text { Prkce } \\
\text { Gprk5 }\end{array}$ & $\begin{array}{l}1.57 \pm 0.05 \\
1.54 \pm 0.01 \\
1.53 \pm 0.01 \\
1.52 \pm 0.05 \\
1.46 \pm 0.01 \\
1.44 \pm 0.06 \\
1.44 \pm 0.18 \\
1.40 \pm 0.06 \\
1.35 \pm 0.20 \\
1.32 \pm 0.03 \\
1.32 \pm 0.08 \\
1.31 \pm 0.05 \\
1.23 \pm 0.12 \\
1.21 \pm 0.01 \\
1.15 \pm 0.18 \\
1.13 \pm 0.13 \\
1.11 \pm 0.16 \\
1.09 \pm 0.09 \\
1.08 \pm 0.18 \\
1.08 \pm 0.14 \\
1.06 \pm 0.04 \\
1.06 \pm 0.02 \\
1.05 \pm 0.01 \\
1.04 \pm 0.0 \\
1.03 \pm 0.05 \\
1.02 \pm 0.03 \\
1.01 \pm 0.05 \\
1.0 \pm 0.09\end{array}$ & $\begin{array}{l}1.97 \pm 0.08 \\
1.47 \pm 0.07 \\
1.02 \pm 0.04 \\
0.84 \pm 0.12 \\
4.55 \pm 0.28 \\
1.35 \pm 0.09 \\
2.92 \pm 0.22 \\
0.88 \pm 0.12 \\
3.70 \pm 0.27 \\
0.79 \pm 0.06 \\
0.36 \pm 0.03 \\
1.36 \pm 0.04 \\
1.26 \pm 0.04 \\
1.07 \pm 0.12 \\
1.79 \pm 0.16 \\
1.64 \pm 0.28 \\
0.49 \pm 0.02 \\
2.53 \pm 0.81 \\
0.67 \pm 0.17 \\
0.32 \pm 0.07 \\
\\
1.01 \pm 0.09 \\
0.93 \pm 0.13 \\
0.09 \pm 0.01 \\
0.60 \pm 0.06 \\
0.93 \pm 0.09 \\
0.42 \pm 0.03 \\
0.58 \pm 0.11 \\
0.82 \pm 0.01\end{array}$ \\
\hline $\begin{array}{l}\text { Gene Name } \\
\text { Janus kinase } 1 \\
\text { fyn-related kinase } \\
\text { PTK2 protein tyrosine kinase } 2 \\
\text { dual-specificity tyrosine-(Y)-phosphorylation regulated kinase } \\
2 \text { (predicted) } \\
\text { similar to tyrosine kinase Fps/Fes (predicted) } \\
\text { tec protein tyrosine kinase } \\
\text { c-src tyrosine kinase }\end{array}$ & $\begin{array}{l}\text { Gene Symbol } \\
\text { Jak1 } \\
\text { Frk } \\
\text { Ptk2 } \\
\text { Dyrk2_predicted } \\
\text { RGD1564385_predi cted } \\
\text { Tec } \\
\text { Csk }\end{array}$ & $\begin{array}{c}\text { IMCD-Signal } \\
\text { Mean } \pm \text { SE } \\
9.69 \pm 0.05 \\
5.58 \pm 0.34 \\
2.28 \pm 0.05 \\
2.06 \pm 0.12 \\
\\
1.53 \pm 0.14 \\
1.52 \pm 0.09 \\
1.16 \pm 0.08\end{array}$ & $\begin{array}{c}\text { non-IMCD-Signal } \\
\text { Mean } \pm \text { SE } \\
9.42 \pm 0.26 \\
0.24 \pm 0.14 \\
2.23 \pm 0.16 \\
2.29 \pm 0.15 \\
\\
1.08 \pm 0.13 \\
0.96 \pm 0.08 \\
3.0 \pm 0.15\end{array}$ \\
\hline $\begin{array}{l}\text { Gene Name } \\
\text { fibroblast growth factor receptor } 2 \\
\text { Met proto-oncogene } \\
\text { epidermal growth factor receptor } \\
\text { receptor-like tyrosine kinase } \\
\text { Eph receptor A2 (predicted) } \\
\text { discoidin domain receptor family, member } 1 \\
\text { fibroblast growth factor receptor } 1 \\
\text { insulin receptor } \\
\text { v-erb-b2 erythroblastic leukemia viral oncogene homolog } 2 \text {, } \\
\text { neuro/glioblastoma derived oncogene homolog (avian) }\end{array}$ & $\begin{array}{l}\text { Gene Symbol } \\
\text { Fgfr2 } \\
\text { Met } \\
\text { Egfr } \\
\text { Ryk } \\
\text { Epha2_predicted } \\
\text { Ddr1 } \\
\text { Fgfr1 } \\
\text { Insr } \\
\text { Erbb2 }\end{array}$ & $\begin{array}{l}\text { IMCD-Signal } \\
\text { Mean } \pm \text { SE } \\
10.09 \pm 0.24 \\
5.55 \pm 0.10 \\
3.41 \pm 0.35 \\
3.26 \pm 0.26 \\
2.91 \pm 0.18 \\
1.78 \pm 0.07 \\
1.62 \pm 0.06 \\
1.61 \pm 0.10 \\
1.43 \pm 0.08\end{array}$ & $\begin{array}{l}\text { non-IMCD-Signal } \\
\text { Mean } \pm \text { SE } \\
-0.29 \pm 0.24 \\
4.83 \pm 0.33 \\
0.57 \pm 0.07 \\
1.76 \pm 0.19 \\
2.37 \pm 0.65 \\
0.75 \pm 0.11 \\
0.94 \pm 0.15 \\
0.72 \pm 0.05 \\
0.93 \pm 0.09\end{array}$ \\
\hline
\end{tabular}


Protein phosphatases

Table 6

Table 6A. Serine/threonine phosphatases with IMCD signals above median.

Table 6B. Tyrosine phosphatases with IMCD signals above median.

Table 6C. Dual specificity phosphatases with IMCD signals above median.

\begin{tabular}{|c|c|c|c|}
\hline Gene Name & Gene Symbol & $\begin{array}{l}\text { IMCD-Signal Mean } \\
\quad \pm \text { SE }\end{array}$ & $\begin{array}{l}\text { non-IMCD-Signal } \\
\quad \text { Mean } \pm \text { SE }\end{array}$ \\
\hline protein phosphatase 1 , catalytic subunit, beta isoform & Ppp1cb & $18.11 \pm 0.06$ & $9.36 \pm 0.60$ \\
\hline protein phosphatase 1 , catalytic subunit, gamma isoform & Ppplcc & $17.59 \pm 0.77$ & $9.94 \pm 0.52$ \\
\hline protein phosphatase 1 , catalytic subunit, alpha isoform & Ppplca & $15.14 \pm 0.03$ & $10.81 \pm 0.15$ \\
\hline $\begin{array}{l}\text { protein phosphatase 2, regulatory subunit A (PR 65), } \\
\text { alpha isoform }\end{array}$ & Ppp2r1a & $8.46 \pm 0.05$ & $3.37 \pm 0.10$ \\
\hline $\begin{array}{l}\text { protein phosphatase } 3 \text {, regulatory subunit B, alpha } \\
\text { isoform (calcineurin B, type I) }\end{array}$ & Ppp3r1 & $6.79 \pm 0.12$ & $1.89 \pm 0.10$ \\
\hline $\begin{array}{l}\text { protein phosphatase } 2 \mathrm{C} \text {, magnesium dependent, catalytic } \\
\text { subunit }\end{array}$ & Ppm2c & $6.22 \pm 0.43$ & $-0.63 \pm 0.17$ \\
\hline protein phosphatase 2 , regulatory subunit $\mathrm{B}^{\prime \prime}$, alpha & Ppp2r3a & $5.76 \pm 0.26$ & $0.12 \pm 0.27$ \\
\hline $\begin{array}{l}\text { protein phosphatase } 1 \mathrm{~B} \text {, magnesium dependent, beta } \\
\text { isoform }\end{array}$ & Ppm1b & $4.40 \pm 0.05$ & $3.17 \pm 0.14$ \\
\hline $\begin{array}{l}\text { protein phosphatase } 2 \text {, regulatory subunit A (PR 65), beta } \\
\text { isoform }\end{array}$ & Ppp2r1b & $4.05 \pm 0.28$ & $1.51 \pm 0.02$ \\
\hline $\begin{array}{l}\text { protein phosphatase } 2 \text {, regulatory subunit B (B56), alpha } \\
\text { isoform (predicted) }\end{array}$ & Ppp2r5a_predicted & $3.98 \pm 0.13$ & $18.52 \pm 0.62$ \\
\hline $\begin{array}{l}\text { protein phosphatase 2, regulatory subunit B (PR 52), } \\
\text { alpha isoform }\end{array}$ & Ppp2r2a & $3.47 \pm 0.13$ & $2.46 \pm 0.14$ \\
\hline $\begin{array}{l}\text { protein phosphatase 2, regulatory subunit B (B56), } \\
\text { epsilon isoform (predicted) }\end{array}$ & Ppp2r5e_predicted & $3.16 \pm 0.15$ & $3.37 \pm 0.36$ \\
\hline $\begin{array}{l}\text { protein phosphatase } 1 \mathrm{G} \text {, magnesium-dependent, gamma } \\
\text { isoform }\end{array}$ & Ppm1g & $2.88 \pm 0.06$ & $2.78 \pm 0.40$ \\
\hline protein phosphatase 3 , catalytic subunit, alpha isoform & Рpp3ca & $2.55 \pm 0.21$ & $5.57 \pm 0.30$ \\
\hline protein phosphatase 4 , regulatory subunit 1 & Ppp4r1 & $2.46 \pm 0.01$ & $1.15 \pm 0.07$ \\
\hline $\begin{array}{l}\text { protein phosphatase 1D magnesium-dependent, delta } \\
\text { isoform (predicted) }\end{array}$ & Ppm1d_predicted & $2.36 \pm 0.22$ & $1.26 \pm 0.01$ \\
\hline $\begin{array}{l}\text { protein phosphatase } 2 \text {, regulatory subunit } B \text {, delta } \\
\text { isoform }\end{array}$ & Ppp2r2d & $1.81 \pm 0.05$ & $2.21 \pm 0.11$ \\
\hline $\begin{array}{l}\text { protein phosphatase } 2 \text {, regulatory subunit } B \text { (PR 52), beta } \\
\text { isoform }\end{array}$ & Ppp2r2b & $1.77 \pm 0.03$ & $0.28 \pm 0.09$ \\
\hline $\begin{array}{l}\text { protein phosphatase 2, regulatory subunit B (B56), beta } \\
\text { isoform }\end{array}$ & Ppp2r5b & $1.68 \pm 0.07$ & $1.04 \pm 0.13$ \\
\hline $\begin{array}{l}\text { integrin-linked kinase-associated serine/threonine } \\
\text { phosphatase 2C }\end{array}$ & Ilkap & $1.27 \pm 0.07$ & $1.63 \pm 0.10$ \\
\hline protein phosphatase 3 , catalytic subunit, beta isoform & Ppp3cb & $1.24 \pm 0.14$ & $1.72 \pm 0.03$ \\
\hline $\begin{array}{l}\text { protein phosphatase } 1 \mathrm{~A} \text {, magnesium dependent, alpha } \\
\text { isoform }\end{array}$ & Ppm1a & $1.04 \pm 0.02$ & $0.69 \pm 0.05$ \\
\hline
\end{tabular}

\section{Gene Name}

protein tyrosine phosphatase $4 \mathrm{a} 1$

protein tyrosine phosphatase $4 \mathrm{a} 2$

protein tyrosine phosphatase, receptor type, $\mathrm{F}$

myotubularin related protein 2 (predicted)

protein tyrosine phosphatase, non-receptor type 18

protein tyrosine phosphatase, non-receptor type 2

protein tyrosine phosphatase, mitochondrial 1

similar to protein Tyr phosphatase

protein tyrosine phosphatase, non-receptor type 3

protein tyrosine phosphatase, non-receptor type 21

protein tyrosine phosphatase, non-receptor type 11

protein tyrosine phosphatase, receptor type, $\mathbf{J}$

protein tyrosine phosphatase, receptor type, $\mathrm{G}$

protein tyrosine phosphatase domain containing 1

(predicted)

protein tyrosine phosphatase, receptor type, $\mathrm{K}$,

extracellular region

protein tyrosine phosphatase, receptor type, $\mathrm{M}$

Gene Symbol
Ptp4a1
Ptp4a2
Ptprf
Mtmr2_predicted
Ptpn18
Ptpn2
Ptpmt1
LOC498331
Ptpn3
Ptpn21
Ptpn11
Ptprj
Ptprg
Ptpdc1_predicted
Ptprk
Ptprm

\section{Gene Symbol}

dual specificity phosphatase 1

dual specificity phosphatase 6

dual specificity phosphatase 2

dual specificity phosphatase 5

dual specificity phosphatase 14 (predicted)
Dusp1

Dusp6

Dusp2

Dusp14_predicted

$\begin{array}{cc}\begin{array}{c}\text { IMCD-Signal Mean } \\ \mathbf{\pm S E}\end{array} & \begin{array}{c}\text { non-IMCD-Signal } \\ \text { Mean } \pm \text { SE }\end{array} \\ 21.24 \pm 0.28 & 9.22 \pm 1.20 \\ 1.65 \pm 0.11 & 9.17 \pm 0.47 \\ 9.67 \pm 0.05 & 9.45 \pm 0.47 \\ 6.80 \pm 0.10 & 3.79 \pm 0.25 \\ 5.04 \pm 0.40 & 4.23 \pm 0.67 \\ 4.54 \pm 0.23 & 0.79 \pm 0.06 \\ 4.45 \pm 0.18 & 3.0 \pm 0.28 \\ 3.69 \pm 0.30 & 6.30 \pm 0.29 \\ 3.24 \pm 0.20 & 0.64 \pm 0.07 \\ 2.61 \pm 0.08 & 1.10 \pm 0.02 \\ 2.39 \pm 0.17 & 2.55 \pm 0.05 \\ 1.60 \pm 0.06 & 0.51 \pm 0.10 \\ 1.51 \pm 0.19 & 1.91 \pm 0.13 \\ 1.17 \pm 0.11 & 1.08 \pm 0.02 \\ 1.16 \pm 0.02 & 1.26 \pm 0.11 \\ 1.14 \pm 0.13 & 1.16 \pm 0.20\end{array}$

IMCD-Signal Mean

\pm SE

$21.46 \pm 1.65$

$10.80 \pm 0.29$

$10.31 \pm 0.79$

$8.52 \pm 0.33$

$2.49 \pm 0.34$
non-IMCD-Signal

Mean $\pm \mathbf{S E}$

$30.23 \pm 1.48$

$7.69 \pm 0.62$

$0.45 \pm 0.53$

$0.45 \pm 0.18$

$0.77 \pm 0.11$ 


\begin{tabular}{llcc}
\hline Gene Name & Gene Symbol & $\begin{array}{c}\text { IMCD-Signal Mean } \\
\pm \text { SE }\end{array}$ & $\begin{array}{c}\text { non-IMCD-Signal } \\
\text { Mean } \pm \text { SE }\end{array}$ \\
\hline dual specificity phosphatase 22 (predicted) & Dusp22_predicted & $1.65 \pm 0.05$ & $2.47 \pm 0.09$ \\
dual specificity phosphatase 7 & Dusp7 & $1.45 \pm 0.07$ & $1.85 \pm 0.11$ \\
slingshot homolog 3 (Drosophila) & Ssh3 & $1.03 \pm 0.02$ & $1.08 \pm 0.07$ \\
\hline
\end{tabular}


Table 7

A kinase anchor proteins (AKAP).

\begin{tabular}{llcc}
\hline Gene Name & Gene Symbol & $\begin{array}{c}\text { IMCD-Signal Mean } \pm \\
\text { SE }\end{array}$ & $\begin{array}{c}\text { non-IMCD-Signal } \\
\text { Mean } \pm \text { SE }\end{array}$ \\
\hline A kinase (PRKA) anchor protein 11 & & Akap11 & $21.87 \pm 01.39$ \\
A kinase (PRKA) anchor protein (yotiao) 9 & Akap9 & $2.81 \pm 0.12$ & $-1.63 \pm 0.41$ \\
A kinase (PRKA) anchor protein 8 & Akap8 & $2.29 \pm 0.01$ & $2.50 \pm 0.22$ \\
A kinase (PRKA) anchor protein 13 & Akap13 & $1.52 \pm 0.05$ & $2.66 \pm 0.31$ \\
A kinase (PRKA) anchor protein 7 & Akap7 & $1.05 \pm 0.08$ & $2.27 \pm 0.05$ \\
A kinase (PRKA) anchor protein 10 (predicted) & Akap10_predicted & $0.82 \pm 0.02$ & $1.33 \pm 0.08$ \\
A kinase (PRKA) anchor protein 1 & Akap1 & $0.54 \pm 0.02$ & $1.0 \pm 0.12$ \\
A kinase (PRKA) anchor protein 5 & Akap5 & $0.21 \pm 0.01$ & $0.35 \pm 0.02$ \\
A kinase (PRKA) anchor protein 2 & Akap2 & $0.09 \pm 0.03$ & $0.23 \pm 0.02$ \\
A kinase (PRKA) anchor protein (gravin) 12 & Akap12 & $0.04 \pm 0.13$ & $1.42 \pm 0.12$ \\
& & & $6.07 \pm 1.46$ \\
\hline
\end{tabular}


Table 8

Phospholipases.

\begin{tabular}{|c|c|c|c|}
\hline Gene Name & Gene Symbol & $\begin{array}{c}\text { IMCD-Signal } \\
\text { Mean } \pm \text { SE }\end{array}$ & $\begin{array}{c}\text { non-IMCD-Signal } \\
\text { Mean } \pm \text { SE }\end{array}$ \\
\hline $\begin{array}{l}\text { lysophospholipase } 1 \\
\text { monoglyceride lipase } \\
\text { phospholipase A2, group IVA (cytosolic, calcium- } \\
\text { dependent) } \\
\text { phospholipase C, beta } 4 \\
\text { phospholipase C, beta } 1 \\
\text { lysophospholipaseLysophospholipase-like } 1 \text { (predicted) } \\
\text { lysophospholipase } 2 \\
\text { phospholipase C, delta } 4 \\
\text { DDHD domain containing } 1 \\
\text { phospholipase D family, member } 3 \\
\text { phospholipase D2 } \\
\text { phospholipase C, gamma } 11 \\
\text { phospholipase A2, group VI } \\
\text { hypothetical protein LK } 44 \\
\text { SEC23 interacting protein } \\
\text { similar to FLJ0414 protein (predicted) } \\
\text { phospholipase D1 } \\
\text { phospholipase C, delta } 3 \text { (predicted) } \\
\text { phosphatidylserine-specific phospholipase A1 } \\
\text { phospholipase C, delta } 1 \\
\text { phospholipase C, gamma } 2 \\
\text { similar to phospholipase D family, member } 4\end{array}$ & $\begin{array}{l}\text { Lypla1 } \\
\text { Mgll } \\
\text { Pla2g4a } \\
\text { Plcb4 } \\
\text { Plcb1 } \\
\text { Lyplal1_predicted } \\
\text { Lypla2 } \\
\text { Plcd4 } \\
\text { Ddhd1 } \\
\text { Pld3 } \\
\text { Pld2 } \\
\text { Plcg1 } \\
\text { Pla2g6 } \\
\text { RGD735140 } \\
\text { Sec23ip } \\
\text { RGD1304675_predi cted } \\
\text { Pld1 } \\
\text { Plcd3_predicted } \\
\text { Pspla1 } \\
\text { Plcd1 } \\
\text { Plcg2 } \\
\text { LOC362792 }\end{array}$ & $\begin{array}{c}5.96 \pm 0.17 \\
5.78 \pm 0.22 \\
3.85 \pm 0.27 \\
\\
3.60 \pm 0.17 \\
2.49 \pm 0.20 \\
2.36 \pm 0.09 \\
1.85 \pm 0.04 \\
1.31 \pm 0.10 \\
1.19 \pm 0.06 \\
1.16 \pm 0.02 \\
1.0 \pm 0.02 \\
0.83 \pm 0.04 \\
0.68 \pm 0.07 \\
0.62 \pm 0.05 \\
0.58 \pm 0.03 \\
0.34 \pm 0.04 \\
0.18 \pm 0.04 \\
0.08 \pm 0.03 \\
-0.03 \pm 0.05 \\
-0.05 \pm 0.02 \\
-0.05 \pm 0.03 \\
-1.02 \pm 0.04\end{array}$ & $\begin{array}{c}3.62 \pm 0.31 \\
2.35 \pm 0.13 \\
3.15 \pm 0.14 \\
\\
2.18 \pm 0.28 \\
-0.05 \pm 0.15 \\
1.12 \pm 0.08 \\
0.65 \pm 0.04 \\
-0.25 \pm 0.06 \\
0.59 \pm 0.10 \\
0.79 \pm 0.04 \\
1.02 \pm 0.12 \\
2.28 \pm 0.27 \\
0.47 \pm 0.04 \\
1.07 \pm 0.01 \\
0.85 \pm 0.04 \\
0.40 \pm 0.09 \\
0.38 \pm 0.07 \\
0.64 \pm 0.08 \\
0.68 \pm 0.08 \\
0.48 \pm 0.04 \\
0.85 \pm 0.01 \\
4.53 \pm 0.17\end{array}$ \\
\hline
\end{tabular}




\section{Small GTP-binding proteins}

Table 9

Table 9A. Rab small GTP-binding proteins (Rab family) with IMCD signals above median.

Table 9B. Arf small GTP-binding proteins (Arf/Sar1 family) with IMCD signals above median.

Table 9C. Rho small GTP-binding proteins (Rho/Rac/Cdc42 family) with IMCD signals above median.

Table 9D. Ras and Ras-related small GTP-binding proteins (Ras family) with IMCD signals above median.

\begin{tabular}{|c|c|c|c|}
\hline Gene Name & Gene Symbol & $\begin{array}{c}\text { IMCD-Signal Mean } \\
\quad \pm \text { SE }\end{array}$ & $\begin{array}{c}\text { non-IMCD-Signal } \\
\text { Mean } \pm \text { SE }\end{array}$ \\
\hline $\begin{array}{l}\text { Rab1, member Ras oncogene family } \\
\text { Rab12, member Ras oncogene family } \\
\text { Rab2, member Ras oncogene family } \\
\text { Rab7, member Ras oncogene family } \\
\text { Rab6A, member Ras oncogene family } \\
\text { Rab11A, member Ras oncogene family } \\
\text { Rab10, member Ras oncogene family } \\
\text { Rab9, member Ras oncogene family } \\
\text { Rab18, member Ras oncogene family } \\
\text { Rab28, member Ras oncogene family } \\
\text { Rab11B, member Ras oncogene family } \\
\text { Rab5B, member Ras oncogene family (predicted) } \\
\text { Rab21, member Ras oncogene family } \\
\text { Rab15, member Ras onocogene family } \\
\text { Rab31, member Ras oncogene family } \\
\text { Rab5A, member Ras oncogene family } \\
\text { Rab8A, member Ras oncogene family } \\
\text { Rab25, member Ras oncogene family (predicted) } \\
\text { Rab7, member Ras oncogene family-like } 1 \\
\text { Rab2B, member Ras oncogene family } \\
\text { Rab14, member Ras oncogene family } \\
\text { Rab5C, member Ras oncogene family (predicted) } \\
\text { Rab8B, member Ras oncogene family } \\
\text { Rab34, member of Ras oncogene family } \\
\text { Rab35, member Ras oncogene family } \\
\text { Rab4B, member Ras oncogene family } \\
\text { TBC1 domain family, member } 7 \text { (predicted) }\end{array}$ & $\begin{array}{l}\text { Rab1 } \\
\text { Rab12 } \\
\text { Rab2 } \\
\text { Rab7 } \\
\text { Rab6a } \\
\text { Rab11a } \\
\text { Rab10 } \\
\text { Rab9 } \\
\text { Rab18 } \\
\text { Rab28 } \\
\text { Rab11b } \\
\text { Rab5b_predicted } \\
\text { Rab21 } \\
\text { Rab15 } \\
\text { Rab31 } \\
\text { Rab5a } \\
\text { Rab8a } \\
\text { Rab25_predicted } \\
\text { Rab711 } \\
\text { Rab2b } \\
\text { Rab14 } \\
\text { Rab5c_predicted } \\
\text { Rab8b } \\
\text { Rab34 } \\
\text { Rab35 } \\
\text { Rab4b } \\
\text { Tbc1d7_predicted }\end{array}$ & $\begin{array}{c}33.86 \pm 1.16 \\
20.91 \pm 0.41 \\
20.38 \pm 0.90 \\
18.79 \pm 0.27 \\
17.13 \pm 0.39 \\
14.80 \pm 0.26 \\
11.99 \pm 0.14 \\
9.26 \pm 1.10 \\
7.88 \pm 0.29 \\
7.56 \pm 0.19 \\
7.37 \pm 0.03 \\
7.27 \pm 0.14 \\
5.46 \pm 0.12 \\
5.23 \pm 0.41 \\
5.16 \pm 0.05 \\
4.83 \pm 0.03 \\
4.02 \pm 0.08 \\
3.87 \pm 0.33 \\
3.55 \pm 0.08 \\
3.30 \pm 0.32 \\
2.96 \pm 0.20 \\
2.31 \pm 0.06 \\
1.85 \pm 0.03 \\
1.68 \pm 0.07 \\
1.43 \pm 0.18 \\
1.24 \pm 0.07 \\
1.17 \pm 0.10\end{array}$ & $\begin{array}{c}13.73 \pm 1.06 \\
14.23 \pm 1.32 \\
9.82 \pm 0.14 \\
10.85 \pm 0.23 \\
6.54 \pm 0.45 \\
3.99 \pm 0.24 \\
6.46 \pm 0.09 \\
1.58 \pm 0.13 \\
2.77 \pm 0.44 \\
4.46 \pm 0.28 \\
4.41 \pm 0.20 \\
3.29 \pm 0.13 \\
1.78 \pm 0.16 \\
-1.03 \pm 0.13 \\
0.27 \pm 0.20 \\
3.41 \pm 0.31 \\
2.62 \pm 0.40 \\
0.47 \pm 0.15 \\
1.92 \pm 0.27 \\
2.85 \pm 0.47 \\
4.33 \pm 0.42 \\
4.89 \pm 0.54 \\
5.07 \pm 0.53 \\
2.07 \pm 0.10 \\
1.19 \pm 0.23 \\
0.86 \pm 0.10 \\
0.51 \pm 0.12\end{array}$ \\
\hline $\begin{array}{l}\text { Gene Name } \\
\text { ADP-ribosylation factor } 1 \\
\text { ADP-ribosylation factor } 3 \\
\text { ADP-ribosylation factor } 4 \\
\text { ADP-ribosylation factor 4-like (predicted) } \\
\text { ADP-ribosylation factor-like } 1 \\
\text { SAR1 gene homolog A (S. cerevisiae) } \\
\text { ADP-ribosylation factor } 6 \\
\text { SAR1 gene homolog B (S. cerevisiae) } \\
\text { ADP-ribosylation factor-like } 6 \text { (predicted) } \\
\text { ADP-ribosylation factor-like } 4 \text { A } \\
\text { ADP-ribosylation factor } 2 \\
\text { ADP-ribosylation factor related protein } 1 \\
\text { ADP-ribosylation factor } 5 \\
\text { ADP-ribosylation factor-like } 3\end{array}$ & $\begin{array}{l}\text { Gene Symbol } \\
\text { Arf1 } \\
\text { Arf3 } \\
\text { Arf4 } \\
\text { Arf41_predicted } \\
\text { Arl1 } \\
\text { Sar1a } \\
\text { Arf6 } \\
\text { Sar1b } \\
\text { Ar16_predicted } \\
\text { Arl4a } \\
\text { Arf2 } \\
\text { Arfrp1 } \\
\text { Arf5 } \\
\text { Arl3 }\end{array}$ & $\begin{array}{c}\text { IMCD-Signal Mean } \\
\pm \text { SE } \\
30.88 \pm 0.79 \\
16.48 \pm 0.34 \\
16.21 \pm 0.64 \\
10.63 \pm 0.90 \\
8.73 \pm 0.38 \\
6.46 \pm 0.21 \\
5.66 \pm 0.18 \\
5.13 \pm 0.02 \\
3.07 \pm 0.02 \\
2.62 \pm 0.04 \\
2.44 \pm 0.08 \\
2.05 \pm 0.04 \\
2.03 \pm 0.07 \\
2.0 \pm 0.09\end{array}$ & $\begin{array}{c}\text { non-IMCD-Signal } \\
\text { Mean } \pm \text { SE } \\
16.78 \pm 1.37 \\
3.71 \pm 0.43 \\
5.78 \pm 0.82 \\
2.47 \pm 0.22 \\
16.81 \pm 1.47 \\
2.65 \pm 0.39 \\
3.44 \pm 0.46 \\
3.10 \pm 0.25 \\
0.42 \pm 0.01 \\
2.62 \pm 0.33 \\
1.07 \pm 0.18 \\
1.42 \pm 0.16 \\
1.72 \pm 0.17 \\
1.71 \pm 0.09\end{array}$ \\
\hline $\begin{array}{l}\text { Gene Name } \\
\text { cell division cycle } 42 \text { homolog (S. cerevisiae) } \\
\text { Rho family GTPase } 1 \\
\text { Ras-related C3 botulinum toxin substrate } 1 \\
\text { Ras homolog gene family, member A } \\
\text { Ras homolog gene family, member B } \\
\text { Rho family GTPase } 3 \\
\text { Ras homolog gene family, member C (predicted) } \\
\text { Ras homolog gene family, member Q } \\
\text { Ras homolog gene family, member G } \\
\text { Ras homolog gene family, member T2 }\end{array}$ & $\begin{array}{l}\text { Gene Symbol } \\
\text { Cdc42 } \\
\text { Rnd1 } \\
\text { Rac1 } \\
\text { Rhoa } \\
\text { Rhob } \\
\text { Rnd3 } \\
\text { Rhoc_predicted } \\
\text { Rhoq } \\
\text { Rhog } \\
\text { Rhot2 }\end{array}$ & $\begin{array}{c}\text { IMCD-Signal Mean } \\
\text { + SE } \\
35.87 \pm 0.87 \\
18.88 \pm 0.33 \\
18.65 \pm 0.19 \\
16.56 \pm 0.73 \\
8.01 \pm 0.42 \\
5.22 \pm 0.17 \\
4.86 \pm 0.08 \\
3.24 \pm 0.13 \\
1.79 \pm 0.05 \\
1.62 \pm 0.10\end{array}$ & $\begin{array}{c}\text { non-IMCD-Signal } \\
\text { Mean } \pm \text { SE } \\
30.81 \pm 2.06 \\
0.51 \pm 0.53 \\
13.62 \pm 0.67 \\
16.01 \pm 1.92 \\
33.09 \pm 2.67 \\
1.37 \pm 0.43 \\
0.62 \pm 0.13 \\
1.70 \pm 0.20 \\
4.67 \pm 0.40 \\
0.90 \pm 0.06\end{array}$ \\
\hline $\begin{array}{l}\text { Gene Name } \\
\text { Ras homolog enriched in brain } \\
\text { Ras related protein 1B } \\
\text { Ras-related associated with diabetes } \\
\text { Ras, dexamethasone-induced } 1\end{array}$ & $\begin{array}{l}\text { Gene Symbol } \\
\text { Rheb } \\
\text { Rap1b } \\
\text { Rrad } \\
\text { Rasd1 }\end{array}$ & $\begin{array}{c}\text { IMCD-Signal Mean } \\
\mathbf{\pm} \text { SE } \\
16.36 \pm 0.31 \\
14.03 \pm 0.4 \\
12.16 \pm 0.92 \\
10.88 \pm 1.23\end{array}$ & $\begin{array}{c}\text { non-IMCD-Signal } \\
\text { Mean } \pm \text { SE } \\
11.12 \pm 0.64 \\
8.61 \pm 0.76 \\
-2.06 \pm 0.12 \\
1.57 \pm 0.84\end{array}$ \\
\hline
\end{tabular}




\begin{tabular}{llc}
\hline Gene Name & Gene Symbol & $\begin{array}{c}\text { IMCD-Signal Mean } \\
\pm \text { SE }\end{array}$ \\
& & $\begin{array}{c}\text { non-IMCD-Signal } \\
\text { Mean } \pm \text { SE }\end{array}$ \\
\hline related Ras viral (r-Ras) oncogene homolog 2 & Rras2 & $8.78 \pm 0.14$ \\
Ras-related GTP binding A & Rraga & $6.68 \pm 0.23$ \\
Ras-related protein 1A & Rap1a & $5.74 \pm 0.14$ \\
V-Ral simian leukemia viral oncogene homolog A (Ras & Rala & $5.42 \pm 0.41$ \\
related) & & $5.32 \pm 0.35$ \\
v-Ki-Ras2 Kirsten rat sarcoma viral oncogene homolog & Kras & $5.45 \pm 0.4$ \\
Ras-related GTP binding C (predicted) & Rragc_predicted & $3.5 \pm 0.19$ \\
Ras-related GTP binding D (predicted) & Rragd_predicted & $2.75 \pm 0.25$ \\
muscle and microspikes Ras & Mras & $2.63 \pm 0.22$ \\
Harvey rat sarcoma viral (v-Ha-Ras) oncogene homolog & Hras & $1.62 \pm 0.04$ \\
v-Ral simian leukemia viral oncogene homolog B & Ralb & $1.57 \pm 0.04$ \\
neuroblastoma Ras oncogene & Nras & $1.4 \pm 0.1$ \\
Harvey rat sarcoma oncogene, subgroup R (predicted) & Rras_predicted & $1.34 \pm 0.1$ \\
& & $4.19 \pm 0.13$ \\
\end{tabular}


SNAREs and SNARE-related proteins.

Table 10

\begin{tabular}{|c|c|c|c|}
\hline Gene Name & Gene Symbol & $\underset{\text { SE }}{\operatorname{IMCD}}$ & $\begin{array}{c}\text { non-IMCD-Signal } \\
\text { Mean } \pm \text { SE }\end{array}$ \\
\hline syntaxin 7 & Stx7 & $24.43 \pm 1.36$ & $8.32 \pm 0.40$ \\
\hline vesicle-associated membrane protein 8 & VAMP8 & $9.12 \pm 0.25$ & $6.46 \pm 0.09$ \\
\hline $\begin{array}{l}\text { N-ethylmaleimide-sensitive factor attachment protein, } \\
\text { gamma }\end{array}$ & Napg & $8.06 \pm 0.07$ & $1.15 \pm 0.07$ \\
\hline $\begin{array}{l}\text { similar to NipSnap2 protein (Glioblastoma amplified } \\
\text { sequence) }\end{array}$ & LOC498174 & $6.27 \pm 0.19$ & $3.55 \pm 0.34$ \\
\hline syntaxin 12 & Stx 12 & $6.27 \pm 0.21$ & $3.09 \pm 0.11$ \\
\hline vesicle-associated membrane protein 3 & Vamp3 & $5.73 \pm 0.14$ & $3.33 \pm 0.35$ \\
\hline syntaxin binding protein 3 & Stxbp3 & $5.61 \pm 0.17$ & $3.10 \pm 0.12$ \\
\hline SNAP-associated protein & Snapap & $5.0 \pm 0.35$ & $2.58 \pm 0.06$ \\
\hline Golgi SNAP receptor complex member 2 & Gosr2 & $3.99 \pm 0.16$ & $0.74 \pm 0.13$ \\
\hline syntaxin $4 \mathrm{~A}$ (placental) & Stx4a & $3.78 \pm 0.09$ & $4.39 \pm 0.09$ \\
\hline blocked early in transport 1 homolog (S. cerevisiae) & Bet1 & $2.86 \pm 0.18$ & $1.62 \pm 0.02$ \\
\hline Golgi SNAP receptor complex member 1 & Gosr1 & $2.47 \pm 0.09$ & $1.07 \pm 0.22$ \\
\hline similar to T-Brain-1 & LOC311078 & $2.44 \pm 0.08$ & $1.75 \pm 0.15$ \\
\hline SEC22 vesicle trafficking protein-like 1 (S. cerevisiae) & Sec2211 & $2.13 \pm 0.12$ & $0.95 \pm 0.13$ \\
\hline syntaxin binding protein 2 & Stxbp2 & $2.02 \pm 0.04$ & $0.56 \pm 0.05$ \\
\hline syntaxin 8 & Stx 8 & $1.98 \pm 0.04$ & $1.36 \pm 0.04$ \\
\hline syntaxin $5 \mathrm{a}$ & Stx5a & $1.98 \pm 0.05$ & $1.52 \pm 0.13$ \\
\hline synaptosomal-associated protein 29 & Snap29 & $1.95 \pm 0.06$ & $1.11 \pm 0.07$ \\
\hline vesicle-associated membrane protein 4 (predicted) & Vamp4_predicted & $1.94 \pm 0.04$ & $1.19 \pm 0.04$ \\
\hline synaptosomal-associated protein 23 & Snap 23 & $1.86 \pm 0.03$ & $3.15 \pm 0.36$ \\
\hline N-ethylmaleimide sensitive fusion protein & $\mathrm{Nsf}^{*}$ & $1.72 \pm 0.0$ & $0.83 \pm 0.13$ \\
\hline prenylated SNARE protein & Ykt6 & $1.53 \pm 0.08$ & $1.06 \pm 0.13$ \\
\hline vesicle-associated membrane protein 2 & Vamp2 & $1.53 \pm 0.03$ & $1.88 \pm 0.19$ \\
\hline 4-nitrophenylphosphatase domain and non-neuronal & Nipsnap1 & $1.43 \pm 0.15$ & $0.60 \pm 0.02$ \\
\hline SNAP25-like protein homolog 1 (C. elegans) & & & \\
\hline $\begin{array}{l}\text { vesicle transport through interaction with t-SNAREs } \\
\text { homolog } 1 \mathrm{~A} \text { (yeast) }\end{array}$ & Vtila & $1.23 \pm 0.06$ & $3.08 \pm 0.18$ \\
\hline vesicle-associated membrane protein 1 & Vamp1 & $0.85 \pm 0.07$ & $0.76 \pm 0.07$ \\
\hline synaptotagmin-like 4 & Sytl4 & $0.51 \pm 0.04$ & $0.0 \pm 0.02$ \\
\hline blocked early in transport 1 homolog (S. cerevisiae) like & Bet11 & $0.44 \pm 0.03$ & $0.57 \pm 0.04$ \\
\hline nipsnap homolog 3A (C. elegans) & Nipsnap3a & $0.40 \pm 0.06$ & $0.85 \pm 0.10$ \\
\hline syntaxin 11 & Stx11 & $0.40 \pm 0.02$ & $0.50 \pm 0.05$ \\
\hline synaptotagmin-like 2 (predicted) & Syt12_predicted & $0.36 \pm 0.10$ & $4.60 \pm 0.11$ \\
\hline syntaxin binding protein 5 (tomosyn) & Stxbp5 & $0.29 \pm 0.02$ & $0.58 \pm 0.03$ \\
\hline syntaxin 3 & Stx3 & $0.22 \pm 0.03$ & $0.19 \pm 0.03$ \\
\hline syntaxin 1A (brain) & Stx 1a & $0.21 \pm 0.02$ & $0.14 \pm 0.03$ \\
\hline syntaxin binding protein 1 & Stxbp1 & $0.12 \pm 0.04$ & $0.25 \pm 0.02$ \\
\hline
\end{tabular}


Table 11

Coat proteins and clathrin adaptors.

\begin{tabular}{|c|c|c|c|}
\hline Gene Name & Gene Symbol & $\begin{array}{c}\text { IMCD-Signal } \\
\text { Mean } \pm \text { SE }\end{array}$ & $\begin{array}{l}\text { non-IMCD- } \\
\text { Signal Mean } \pm \\
\text { SE }\end{array}$ \\
\hline clathrin, light polypeptide (Lca) & Clta & $19.43 \pm 0.65$ & $12.23 \pm 0.20$ \\
\hline clathrin, heavy polypeptide $(\mathrm{Hc})$ & Cltc & $15.16 \pm 0.22$ & $13.10 \pm 0.95$ \\
\hline adaptor-related protein complex 2 , mu 1 subunit & Ap2m1 & $14.70 \pm 0.49$ & $14.54 \pm 0.40$ \\
\hline coatomer protein complex subunit alpha & Copa & $10.76 \pm 0.16$ & $8.53 \pm 0.47$ \\
\hline phosphatidylinositol binding clathrin assembly protein & Picalm & $10.41 \pm 0.28$ & $19.58 \pm 0.40$ \\
\hline coatomer protein complex, subunit beta 2 (beta prime) & Copb2 & $7.12 \pm 0.03$ & $4.32 \pm 0.27$ \\
\hline enthoprotin (epsin 4) & Enth & $6.83 \pm 0.08$ & $2.36 \pm 0.38$ \\
\hline coatomer protein complex, subunit beta 1 & Copb1 & $5.82 \pm 0.14$ & $3.88 \pm 0.21$ \\
\hline adaptor protein complex AP-1, sigma 1 (predicted) & Ap1s1_predicted & $5.29 \pm 0.12$ & $1.21 \pm 0.16$ \\
\hline archain 1 & Arcn $1^{-1}$ & $4.69 \pm 0.11$ & $3.18 \pm 0.06$ \\
\hline coatomer protein complex, subunit zeta 1 (predicted) & Copz1_predicted & $4.55 \pm 0.16$ & $4.55 \pm 0.21$ \\
\hline coatomer protein complex, subunit epsilon (predicted) & Cope_predicted & $3.69 \pm 0.05$ & $3.04 \pm 0.15$ \\
\hline epsin 3 & Epn3 & $3.53 \pm 0.13$ & $1.02 \pm 0.15$ \\
\hline adaptor-related protein complex 3 , sigma 1 subunit (predicted) & Ap3s1_predicted & $3.22 \pm 0.14$ & $1.92 \pm 0.10$ \\
\hline NECAP endocytosis associated 2 & Necap 2 & $2.90 \pm 0.20$ & $2.34 \pm 0.16$ \\
\hline adaptor-related protein complex 3 , mu 1 subunit & Ap3m1 & $2.82 \pm 0.24$ & $1.22 \pm 0.19$ \\
\hline adaptor-related protein complex 2 , sigma 1 subunit & Ap2s1 & $2.67 \pm 0.01$ & $2.82 \pm 0.08$ \\
\hline coatomer protein complex, subunit gamma & Copg & $2.65 \pm 0.03$ & $2.06 \pm 0.10$ \\
\hline hypothetical LOC308765 (predicted) & RGD1311021_predi cted & $2.46 \pm 0.12$ & $1.22 \pm 0.11$ \\
\hline clathrin, light polypeptide (Lcb) & Cltb & $1.42 \pm 0.06$ & $2.15 \pm 0.11$ \\
\hline epsin 2 & Epn2 & $1.19 \pm 0.06$ & $1.73 \pm 0.07$ \\
\hline adaptor-related protein complex AP-1, mu subunit 1 & Ap1m1 & $1.01 \pm 0.06$ & $1.64 \pm 0.13$ \\
\hline epsin 1 & Epn1 & $0.69 \pm 0.10$ & $0.42 \pm 0.16$ \\
\hline $\begin{array}{l}\text { Golgi associated, gamma adaptin ear containing, ARF binding } \\
\text { protein } 1\end{array}$ & Gga1 & $0.69 \pm 0.01$ & $0.74 \pm 0.09$ \\
\hline adaptor-related protein complex 3 , mu 2 subunit & Ap3m2 & $0.66 \pm 0.05$ & $0.24 \pm 0.03$ \\
\hline SEC31-like 1 (S. cerevisiae) & Sec3111 & $0.60 \pm 0.04$ & $0.60 \pm 0.02$ \\
\hline coatomer protein complex, subunit zeta 2 (predicted) & Copz2_predicted & $0.38 \pm 0.02$ & $0.34 \pm 0.03$ \\
\hline similar to TICAM-1 & LOC 363328 & $0.27 \pm 0.01$ & $0.26 \pm 0.06$ \\
\hline adaptor-related protein complex 1, sigma 2 subunit (predicted) & Ap1s2_predicted & $-0.52 \pm 0.02$ & $3.60 \pm 0.30$ \\
\hline
\end{tabular}


Table 12

Cytoskeletal proteins and cytoskeletal regulators

Table 12A. Actin and actin-binding proteins.

Table 12B. Myosin and myosin-like proteins.

Table 12C. Microtubule and microtubule-related proteins.

Table 12D. Intermediate filaments and related proteins.

\begin{tabular}{|c|c|c|c|}
\hline Gene Name & Gene Symbol & $\begin{array}{c}\text { IMCD-Signal } \\
\text { Mean } \pm \text { SE }\end{array}$ & $\begin{array}{c}\text { non-IMCD-Signal } \\
\text { Mean } \pm \text { SE }\end{array}$ \\
\hline thymosin, beta 4 & Tmsb4x & $66.99 \pm 1.02$ & $71.67 \pm 7.80$ \\
\hline actin, gamma, cytoplasmic 1 & Actg1 & $60.72 \pm 1.74$ & $53.20 \pm 6.33$ \\
\hline actin, beta & Actb & $53.14 \pm 1.80$ & $45.18 \pm 7.59$ \\
\hline destrin & Dstn & $50.35 \pm 2.15$ & $13.86 \pm 0.49$ \\
\hline catenin (cadherin-associated protein), alpha 1 & Catna1 & $39.85 \pm 0.76$ & $21.23 \pm 2.29$ \\
\hline plastin 3 (T-isoform) & Pls3 & $36.0 \pm 0.35$ & $7.36 \pm 1.29$ \\
\hline spectrin beta 3 & Spnb3 & $34.18 \pm 0.72$ & $-4.57 \pm 0.40$ \\
\hline calponin 3 , acidic & Cnn3 & $33.23 \pm 1.03$ & $3.85 \pm 0.20$ \\
\hline mucin 1 , transmembrane & Muc1 & $29.01 \pm 0.48$ & $11.23 \pm 0.73$ \\
\hline cortactin & $\mathrm{Cttn}$ & $27.53 \pm 0.47$ & $0.32 \pm 0.41$ \\
\hline actin related protein $2 / 3$ complex, subunit 2 (predicted) & Arpc2_predicted & $24.33 \pm 0.29$ & $17.32 \pm 1.19$ \\
\hline tropomyosin 4 & Tpm4 & $24.31 \pm 0.53$ & $2.69 \pm 0.91$ \\
\hline spectrin beta 2 & Spnb2 & $23.76 \pm 0.12$ & $22.34 \pm 1.75$ \\
\hline alpha-spectrin 2 & Spna2 & $22.14 \pm 0.95$ & $22.93 \pm 0.41$ \\
\hline tropomyosin 1 , alpha & Tpm1 & $21.92 \pm 0.41$ & $10.75 \pm 1.26$ \\
\hline capping protein (actin filament), gelsolin-like & Capg & $21.54 \pm 0.10$ & $14.33 \pm 0.49$ \\
\hline actin related protein $2 / 3$ complex, subunit 3 (predicted) & Arpc3_predicted & $20.79 \pm 0.21$ & $12.33 \pm 0.46$ \\
\hline transgelin 2 & Tagln 2 & $19.69 \pm 0.66$ & $9.54 \pm 0.52$ \\
\hline plastin 1 (I isoform) (predicted) & Pls1_predicted & $18.08 \pm 0.99$ & $-2.60 \pm 0.83$ \\
\hline ARP2 actin-related protein 2 homolog (yeast) & Actr 2 & $17.65 \pm 0.37$ & $22.10 \pm 1.52$ \\
\hline capping protein (actin filament) muscle Z-line, beta & Capzb & $15.87 \pm 0.18$ & $11.06 \pm 0.56$ \\
\hline villin 2 & Vil2 & $15.76 \pm 0.51$ & $13.41 \pm 0.38$ \\
\hline tropomyosin 3, gamma & Tpm3 & $15.53 \pm 0.65$ & $7.57 \pm 0.71$ \\
\hline actin related protein $2 / 3$ complex, subunit $1 \mathrm{~B}$ & Arpc1b & $15.26 \pm 0.19$ & $8.73 \pm 0.65$ \\
\hline actinin alpha 4 & Actn 4 & $14.90 \pm 0.64$ & $8.07 \pm 1.06$ \\
\hline $\begin{array}{l}\text { catenin (cadherin associated protein), alpha-like } 1 \\
\text { (predicted) }\end{array}$ & Ctnnal1_predicted & $14.72 \pm 0.23$ & $1.38 \pm 0.23$ \\
\hline LIM and SH3 protein 1 & Lasp1 & $12.92 \pm 0.14$ & $6.41 \pm 0.57$ \\
\hline kelch domain containing $8 \mathrm{~A}$ & Klhdc8a & $12.17 \pm 0.92$ & $5.16 \pm 0.19$ \\
\hline $\mathrm{GABA}(\mathrm{A})$ receptor-associated protein like 2 & Gabarapl2 & $12.16 \pm 0.29$ & $7.52 \pm 0.88$ \\
\hline WD repeat protein 1 & Wdr1 & $11.64 \pm 0.16$ & $5.67 \pm 0.81$ \\
\hline vinculin (predicted) & Vcl_predicted & $11.37 \pm 0.98$ & $4.10 \pm 0.84$ \\
\hline protein tyrosine kinase 9 & Ptk9 & $11.18 \pm 0.45$ & $1.30 \pm 0.44$ \\
\hline cofilin 1 , non-muscle & Cfl1 & $10.19 \pm 0.87$ & $11.61 \pm 1.99$ \\
\hline ARP3 actin-related protein 3 homolog (yeast) & Actr3 & $9.80 \pm 0.23$ & $10.79 \pm 1.12$ \\
\hline actin related protein $2 / 3$ complex, subunit 5 & Arpc5 & $9.09 \pm 0.53$ & $9.75 \pm 0.57$ \\
\hline capping protein (actin filament) muscle Z-line, alpha 2 & Capza2 & $8.58 \pm 0.10$ & $4.07 \pm 0.26$ \\
\hline filamin, beta (predicted) & Flnb_predicted & $8.57 \pm 0.15$ & $7.53 \pm 0.23$ \\
\hline actin related protein $2 / 3$ complex, subunit $1 \mathrm{~A}$ & Arpcla & $8.16 \pm 0.05$ & $1.67 \pm 0.01$ \\
\hline adducin 1 (alpha) & Add1 & $7.54 \pm 0.28$ & $5.48 \pm 0.40$ \\
\hline ectodermal-neural cortex 1 & Enc1 & $7.09 \pm 0.11$ & $2.07 \pm 0.47$ \\
\hline erythrocyte protein band 4.9 (predicted) & Epb4.9_predicted & $6.29 \pm 0.45$ & $2.18 \pm 0.33$ \\
\hline gelsolin & Gsn $-r$ & $5.84 \pm 0.43$ & $6.03 \pm 0.65$ \\
\hline SH3 domain YSC-like 1 (predicted) & Sh3yl1_predicted & $4.97 \pm 0.09$ & $1.02 \pm 0.39$ \\
\hline ARP10 actin-related protein 10 homolog (S. cerevisiae) & Actr 10 & $4.69 \pm 0.05$ & $4.21 \pm 0.43$ \\
\hline kelch-like 2, Mayven (Drosophila) (predicted) & Klhl2_predicted & $4.62 \pm 0.23$ & $0.25 \pm 0.23$ \\
\hline actinin, alpha 1 & Actn 1 & $4.53 \pm 0.08$ & $2.16 \pm 0.12$ \\
\hline huntingtin interacting protein 1 & Hip1 & $4.51 \pm 0.25$ & $3.56 \pm 0.24$ \\
\hline flightless I homolog (Drosophila) & Fliih & $4.36 \pm 0.12$ & $3.52 \pm 0.30$ \\
\hline similar to KIAA 1749 protein (predicted) & RGD1304623_predi cted & $3.99 \pm 0.23$ & $32.69 \pm 0.56$ \\
\hline Golgi autoantigen, Golgin subfamily b, macroGolgin 1 & Golgb1 & $3.91 \pm 0.38$ & $2.42 \pm 0.06$ \\
\hline coronin, actin-binding protein, $1 \mathrm{~B}$ & Corolb & $3.88 \pm 0.08$ & $3.42 \pm 0.33$ \\
\hline drebrin-like & Dbnl & $3.58 \pm 0.12$ & $1.79 \pm 0.21$ \\
\hline kelch-like 7 (Drosophila) & Klhl7 & $3.55 \pm 0.23$ & $2.41 \pm 0.24$ \\
\hline formin binding protein 4 & Fnbp4 & $3.09 \pm 0.31$ & $2.92 \pm 0.06$ \\
\hline PDZ and LIM domain 1 (elfin) & Pdlim1 & $2.84 \pm 0.22$ & $2.09 \pm 0.13$ \\
\hline actin-like $6 \mathrm{~A}$ & Actl6a & $2.73 \pm 0.05$ & $1.64 \pm 0.08$ \\
\hline similar to PDZ domain actin binding protein Shroom & RGD1310470 & $2.72 \pm 0.04$ & $-0.29 \pm 0.06$ \\
\hline parvin, alpha & Parva & $2.70 \pm 0.07$ & $0.35 \pm 0.29$ \\
\hline cofilin 2 , muscle (predicted) & Cf12_predicted & $2.53 \pm 0.18$ & $2.34 \pm 0.29$ \\
\hline $\begin{array}{l}\text { ARP8 actin-related protein } 8 \text { homolog (S. cerevisiae) } \\
\text { (predicted) }\end{array}$ & Actr8_predicted & $2.39 \pm 0.04$ & $1.26 \pm 0.03$ \\
\hline $\begin{array}{l}\text { dishevelled associated activator of morphogenesis } 1 \\
\text { (predicted) }\end{array}$ & Daam1_predicted & $2.23 \pm 0.06$ & $1.81 \pm 0.13$ \\
\hline
\end{tabular}




\begin{tabular}{|c|c|c|c|}
\hline Gene Name & Gene Symbol & $\begin{array}{l}\text { IMCD-Signal } \\
\text { Mean } \pm \text { SE }\end{array}$ & $\begin{array}{l}\text { non-IMCD-Signal } \\
\text { Mean } \pm \text { SE }\end{array}$ \\
\hline $\begin{array}{l}\text { ARP6 actin-related protein } 6 \text { homolog (yeast) } \\
\text { (predicted) }\end{array}$ & Actr6_predicted & $2.12 \pm 0.11$ & $1.57 \pm 0.14$ \\
\hline actin related protein $2 / 3$ complex, subunit 4 (predicted) & Arpc4_predicted & $2.10 \pm 0.16$ & $3.78 \pm 0.76$ \\
\hline filamin, alpha (predicted) & Flna_predicted & $2.06 \pm 0.18$ & $6.48 \pm 0.34$ \\
\hline kelch-like 5 (Drosophila) & Klhl $\overline{5}$ & $1.65 \pm 0.09$ & $1.69 \pm 0.09$ \\
\hline Nebulette (predicted) & Nebl_predicted & $1.59 \pm 0.27$ & $0.35 \pm 0.14$ \\
\hline ankyrin 3 , epithelial & Ank 3 & $1.51 \pm 0.29$ & $1.05 \pm 0.19$ \\
\hline syntrophin, acidic 1 & Snta1 & $1.43 \pm 0.04$ & $0.65 \pm 0.07$ \\
\hline A disintegrin and metalloprotease domain 8 (predicted) & Adam8_predicted & $1.42 \pm 0.03$ & $2.0 \pm 0.05$ \\
\hline smooth muscle alpha-actin & Acta2 & $1.35 \pm 0.13$ & $0.67 \pm 0.09$ \\
\hline dystrobrevin, beta & Dtnb & $1.30 \pm 0.07$ & $4.53 \pm 0.16$ \\
\hline ARP1 actin-related protein 1 homolog B (yeast) & Actr1b & $1.25 \pm 0.08$ & $0.93 \pm 0.10$ \\
\hline $\begin{array}{l}\text { ARP1 actin-related protein } 1 \text { homolog A (yeast) } \\
\text { (predicted) }\end{array}$ & Actr1a_predicted & $1.21 \pm 0.10$ & $2.09 \pm 0.25$ \\
\hline diaphanous homolog 1 (Drosophila) (predicted) & Diap1_predicted & $1.16 \pm 0.05$ & $1.19 \pm 0.10$ \\
\hline enabled homolog (Drosophila) & Enah & $1.14 \pm 0.07$ & $0.80 \pm 0.06$ \\
\hline $\begin{array}{l}\text { tensin like } \mathrm{C} 1 \text { domain containing phosphatase } \\
\text { (predicted) }\end{array}$ & Tenc1_predicted & $0.89 \pm 0.08$ & $1.71 \pm 0.16$ \\
\hline supervillin (predicted) & Svil_predicted & $0.87 \pm 0.01$ & $1.63 \pm 0.03$ \\
\hline cappuccino homolog (mouse) & Cno & $0.85 \pm 0.09$ & $1.92 \pm 0.11$ \\
\hline similar to CG32384-PA (predicted) & RGD1311955_predi cted & $0.83 \pm 0.03$ & $0.25 \pm 0.09$ \\
\hline spectrin alpha 1 & Spna1 & $0.82 \pm 0.11$ & $0.42 \pm 0.04$ \\
\hline huntingtin interacting protein 1 related & Hip1r & $0.79 \pm 0.03$ & $0.97 \pm 0.02$ \\
\hline villin-like (predicted) & Vill_predicted & $0.68 \pm 0.02$ & $1.64 \pm 0.0$ \\
\hline caldesmon 1 & Cald 1 & $0.63 \pm 0.08$ & $-0.01 \pm 0.01$ \\
\hline PDZ and LIM domain 5 & Pdlim5 & $0.61 \pm 0.04$ & $0.16 \pm 0.08$ \\
\hline calponin 1 & Cnn 1 & $0.55 \pm 0.13$ & $1.18 \pm 0.17$ \\
\hline adducin 3 (gamma) & Add3 & $0.52 \pm 0.04$ & $0.77 \pm 0.10$ \\
\hline coronin 7 & Coro7 & $0.49 \pm 0.05$ & $1.35 \pm 0.07$ \\
\hline IAP promoted placental gene (predicted) & Ipp_predicted & $0.45 \pm 0.02$ & $0.19 \pm 0.05$ \\
\hline kelch-like 8 (Drosophila) (predicted) & Klh18_predicted & $0.37 \pm 0.03$ & $0.31 \pm 0.02$ \\
\hline drebrin 1 & Dbn1 & $0.36 \pm 0.08$ & $0.44 \pm 0.11$ \\
\hline kelch-like 25 (Drosophila) & Klhl25 & $0.31 \pm 0.03$ & $0.60 \pm 0.06$ \\
\hline $\begin{array}{l}\text { ARP5 actin-related protein } 5 \text { homolog (yeast) } \\
\text { (predicted) }\end{array}$ & Actr5_predicted & $0.27 \pm 0.01$ & $0.41 \pm 0.04$ \\
\hline coronin, actin binding protein $2 \mathrm{~A}$ & Coro $2 \mathrm{a}$ & $0.26 \pm 0.03$ & $0.13 \pm 0.04$ \\
\hline ankyrin 2 , neuronal & Ank2 & $0.22 \pm 0.01$ & $1.10 \pm 0.11$ \\
\hline coronin, actin binding protein 6 & Coro6 & $0.18 \pm 0.04$ & $0.23 \pm 0.02$ \\
\hline parvin, beta (predicted) & Parvb_predicted & $0.16 \pm 0.01$ & $0.58 \pm 0.09$ \\
\hline WAS protein family, member 2 & Wasf 2 & $0.15 \pm 0.01$ & $0.57 \pm 0.04$ \\
\hline actin related protein $2 / 3$ complex, subunit 5 -like & Arpc51 & $0.15 \pm 0.02$ & $0.12 \pm 0.01$ \\
\hline PDZ and LIM domain 2 & Pdlim2 & $0.12 \pm 0.02$ & $0.30 \pm 0.05$ \\
\hline tensin & Tns & $0.09 \pm 0.03$ & $0.49 \pm 0.07$ \\
\hline WAS protein family, member 1 & Wasf1 & $0.04 \pm 0.01$ & $0.35 \pm 0.05$ \\
\hline $\begin{array}{l}\text { asp (abnormal spindle)-like, microcephaly associated } \\
\text { (Drosophila) (predicted) }\end{array}$ & Aspm_predicted & $0.04 \pm 0.01$ & $0.25 \pm 0.05$ \\
\hline transgelin & Tagln & $-0.04 \pm 0.02$ & $0.49 \pm 0.08$ \\
\hline llymphocyte cytosolic protein 1 & Lcp1 & $-0.18 \pm 0.06$ & $18.16 \pm 0.82$ \\
\hline Ena-vasodilator stimulated phosphoprotein & Evl & $-0.23 \pm 0.03$ & $3.18 \pm 0.13$ \\
\hline formin-like 1 (predicted) & Fmnl1_predicted & $-0.35 \pm 0.08$ & $3.96 \pm 0.29$ \\
\hline coronin, actin binding protein $1 \mathrm{~A}$ & Corola & $-2.54 \pm 0.04$ & $11.01 \pm 0.22$ \\
\hline Gene Name & Gene Symbol & $\begin{array}{l}\text { IMCD-Signal } \\
\text { Mean } \pm \text { SE }\end{array}$ & $\begin{array}{l}\text { non-IMCD-Signal } \\
\text { Mean } \pm \text { SE }\end{array}$ \\
\hline myosin light chain, regulatory $\mathrm{B}$ & Mrlcb & $27.64 \pm 0.84$ & $22.96 \pm 1.85$ \\
\hline myosin, heavy polypeptide 10 , non-muscle & Myh10 & $26.57 \pm 0.37$ & $-1.92 \pm 0.73$ \\
\hline myosin ID & Myo1d & $7.85 \pm 0.02$ & $4.03 \pm 0.08$ \\
\hline myosin, heavy polypeptide 9 , non-muscle & Myh9 & $7.27 \pm 0.13$ & $9.73 \pm 1.98$ \\
\hline myosin Ib & Myolb & $3.79 \pm 0.11$ & $-0.33 \pm 0.16$ \\
\hline myosin 5B & Myo5b & $2.42 \pm 0.09$ & $3.83 \pm 0.18$ \\
\hline similar to myosin XVIIIa & LOC360570 & $2.30 \pm 0.14$ & $2.12 \pm 0.15$ \\
\hline myosin IE & Myole & $1.88 \pm 0.23$ & $1.77 \pm 0.34$ \\
\hline myosin IC & Myolc & $1.84 \pm 0.08$ & $1.83 \pm 0.09$ \\
\hline myosin binding protein $\mathrm{H}$ & Mybph & $1.51 \pm 0.16$ & $0.59 \pm 0.07$ \\
\hline myosin VC (predicted) & Myo5c_predicted & $1.46 \pm 0.03$ & $1.97 \pm 0.08$ \\
\hline myosin X (predicted) & Myo10_predicted & $0.56 \pm 0.0$ & $0.55 \pm 0.04$ \\
\hline myosin, heavy polypeptide 14 & Myh14 & $0.54 \pm 0.02$ & $1.59 \pm 0.02$ \\
\hline myosin IXA & Мyo9a & $0.50 \pm 0.02$ & $0.43 \pm 0.07$ \\
\hline myosin $\mathrm{Va}$ & Myo5a & $0.49 \pm 0.09$ & $0.71 \pm 0.02$ \\
\hline myosin IXb & Myo9b & $0.36 \pm 0.04$ & $1.76 \pm 0.12$ \\
\hline myosin, heavy polypeptide 7 , cardiac muscle, beta & Myh7 & $0.07 \pm 0.01$ & $0.11 \pm 0.01$ \\
\hline myosin, light polypeptide 9 , regulatory (predicted) & Myl9_predicted & $-0.13 \pm 0.06$ & $1.08 \pm 0.17$ \\
\hline myosin VIIA and Rab interacting protein & Myrip & $-0.14 \pm 0.01$ & $0.63 \pm 0.08$ \\
\hline myosin IG & Myo1g & $-0.15 \pm 0.02$ & $1.20 \pm 0.03$ \\
\hline
\end{tabular}




\begin{tabular}{|c|c|c|c|}
\hline Gene Name & Gene Symbol & $\begin{array}{c}\text { IMCD-Signal } \\
\text { Mean } \pm \text { SE }\end{array}$ & $\begin{array}{c}\text { non-IMCD-Signal } \\
\text { Mean } \pm \text { SE }\end{array}$ \\
\hline myosin IF (predicted) & Myo1f_predicted & $-0.46 \pm 0.0$ & $2.13 \pm 0.07$ \\
\hline Gene Name & Gene Symbol & $\begin{array}{l}\text { IMCD-Signal } \\
\text { Mean } \pm \text { SE }\end{array}$ & $\begin{array}{l}\text { non-IMCD-Signal } \\
\text { Mean } \pm \text { SE }\end{array}$ \\
\hline tumor protein, translationally-controlled 1 & Tpt1 & $44.78 \pm 1.48$ & $53.40 \pm 5.56$ \\
\hline gamma-aminobutyric acid receptor associated protein & Gabarap & $17.51 \pm 0.52$ & $12.0 \pm 1.02$ \\
\hline dynein light chain LC8-type 1 & Dynll1 & $11.85 \pm 0.38$ & $20.26 \pm 0.37$ \\
\hline dynein light chain LC8-type 2 & Dynll2 & $10.28 \pm 0.31$ & $4.38 \pm 0.26$ \\
\hline dynein, cytoplasmic, light chain $2 \mathrm{~A}$ & Dncl2a & $10.10 \pm 0.08$ & $6.78 \pm 0.32$ \\
\hline $\begin{array}{l}\text { T-complex associated-testis-expressed 1-like (Protein } \\
91 / 23 \text { ) }\end{array}$ & Tcte11 & $8.26 \pm 0.70$ & $2.15 \pm 0.25$ \\
\hline dynein, cytoplasmic, intermediate chain 2 & Dncic2 & $7.51 \pm 0.20$ & $4.01 \pm 0.35$ \\
\hline microtubule-associated protein 7 (predicted) & Mtap7_predicted & $7.48 \pm 0.03$ & $0.53 \pm 0.09$ \\
\hline $\begin{array}{l}\text { microtubule-associated protein, RP/EB family, } \\
\text { member } 1\end{array}$ & Mapre 1 & $6.20 \pm 0.22$ & $3.86 \pm 0.10$ \\
\hline cytoskeleton-associated protein 1 (predicted) & Ckap1_predicted & $6.13 \pm 0.45$ & $3.52 \pm 0.31$ \\
\hline tubulin, beta $2 \mathrm{c}$ & Tubb2c & $5.36 \pm 0.22$ & $4.79 \pm 0.31$ \\
\hline dynein, cytoplasmic, heavy polypeptide 2 & Dnch2 & $5.05 \pm 0.07$ & $-0.21 \pm 0.13$ \\
\hline kinesin-associated protein 3 (predicted) & Kifap3_predicted & $4.93 \pm 0.19$ & $1.27 \pm 0.26$ \\
\hline $\mathrm{MAP} /$ microtubule affinity-regulating kinase 3 & Mark3 & $4.71 \pm 0.05$ & $3.34 \pm 0.15$ \\
\hline microtubule-associated protein $1 \mathrm{~b}$ & Map1b & $4.64 \pm 0.77$ & $1.22 \pm 0.12$ \\
\hline doublecortin and CaM kinase-like 3 (predicted) & Dcamkl3_predicted & $3.86 \pm 0.19$ & $0.30 \pm 0.02$ \\
\hline microtubule-associated protein 1 light chain 3 beta & Map1lc3b & $3.80 \pm 0.12$ & $1.95 \pm 0.19$ \\
\hline dynactin 6 (predicted) & Dctn6_predicted & $3.77 \pm 0.17$ & $5.16 \pm 0.33$ \\
\hline dynactin 1 & Detn 1 & $3.52 \pm 0.06$ & $3.86 \pm 0.10$ \\
\hline dynein cytoplasmic 1 heavy chain 1 & Dync1h1 & $3.48 \pm 0.05$ & $6.86 \pm 0.29$ \\
\hline t-complex testis expressed 1 & Tctex 1 & $3.42 \pm 0.20$ & $2.77 \pm 0.05$ \\
\hline tubulin, alpha 4 & Tuba4 & $3.37 \pm 0.03$ & $2.63 \pm 0.18$ \\
\hline microtubule-associated protein 1 light chain 3 alpha & Map1lc3a & $3.31 \pm 0.13$ & $2.97 \pm 0.23$ \\
\hline dynactin 2 & Detn2 & $3.26 \pm 0.35$ & $3.29 \pm 0.25$ \\
\hline kinesin family member 16B (predicted) & Kif16b_predicted & $3.23 \pm 0.21$ & $1.68 \pm 0.24$ \\
\hline microtubule-associated protein 2 & Mtap2 & $3.23 \pm 0.05$ & $1.99 \pm 0.16$ \\
\hline nuclear distribution gene $\mathrm{C}$ homolog (Aspergillus) & Nudc & $3.03 \pm 0.06$ & $2.91 \pm 0.13$ \\
\hline similar to KIAA0980 protein (predicted) & RGD1306152_predi cted & $2.96 \pm 0.40$ & $0.19 \pm 0.14$ \\
\hline dynein cytoplasmic 2 light intermediate chain 1 & Dync2li1 & $2.89 \pm 0.18$ & $0.79 \pm 0.18$ \\
\hline tubulin, beta 5 & Tubb5 & $2.88 \pm 0.15$ & $5.05 \pm 0.39$ \\
\hline kinesin family member 12 & Kif12 & $2.81 \pm 0.06$ & $4.65 \pm 0.35$ \\
\hline dynein, cytoplasmic, light intermediate polypeptide 2 & Dncli2 & $2.81 \pm 0.17$ & $2.95 \pm 0.10$ \\
\hline kinesin light chain 2 (predicted) & Klc2_predicted & $2.76 \pm 0.04$ & $1.85 \pm 0.02$ \\
\hline kinesin family member $1 \mathrm{~A}$ & Kifla & $2.73 \pm 0.11$ & $-0.33 \pm 0.10$ \\
\hline MAP/microtubule affinity-regulating kinase 2 & Mark2 & $2.72 \pm 0.02$ & $2.66 \pm 0.20$ \\
\hline dynamin 1-like & Dnm11 & $2.34 \pm 0.19$ & $1.11 \pm 0.20$ \\
\hline dynactin 5 & Dctn5 & $2.26 \pm 0.03$ & $2.46 \pm 0.03$ \\
\hline cytoskeleton associated protein 5 & Ckap5 & $2.04 \pm 0.06$ & $1.88 \pm 0.11$ \\
\hline kinesin light chain 4 & Klc4 & $1.88 \pm 0.02$ & $1.70 \pm 0.14$ \\
\hline kinesin family member $\mathrm{C} 3$ & Kifc3 & $1.83 \pm 0.14$ & $4.57 \pm 0.47$ \\
\hline kinesin 2 & Kns2 & $1.80 \pm 0.08$ & $2.13 \pm 0.23$ \\
\hline cytoplasmic linker 2 & Cyln2 & $1.69 \pm 0.15$ & $1.27 \pm 0.20$ \\
\hline $\begin{array}{l}\text { amyloid beta precursor protein (cytoplasmic tail) } \\
\text { binding protein } 2\end{array}$ & Appbp2 & $1.55 \pm 0.05$ & $0.95 \pm 0.04$ \\
\hline tetratricopeptide repeat domain 23 & $\operatorname{Ttc} 23$ & $1.44 \pm 0.02$ & $0.40 \pm 0.15$ \\
\hline kinesin family member $3 \mathrm{C}$ & Kif3c & $1.44 \pm 0.06$ & $0.43 \pm 0.05$ \\
\hline A disintegrin and metalloprotease domain 8 (predicted) & Adam8_predicted & $1.42 \pm 0.03$ & $2.0 \pm 0.05$ \\
\hline kinesin family member $21 \mathrm{~A}$ (predicted) & Kif21a_predicted & $1.40 \pm 0.04$ & $0.68 \pm 0.05$ \\
\hline tubulin, gamma 1 & Tubg1 & $1.29 \pm 0.07$ & $1.39 \pm 0.08$ \\
\hline dynactin 4 & Dctn4 & $1.19 \pm 0.05$ & $1.0 \pm 0.17$ \\
\hline kinesin family member $3 \mathrm{~B}$ (predicted) & Kif3b_predicted & $1.15 \pm 0.10$ & $0.79 \pm 0.04$ \\
\hline dynein, axonemal, light chain 4 & Dnalc4 & $1.13 \pm 0.07$ & $0.78 \pm 0.13$ \\
\hline optic atrophy 1 homolog (human) & Opal & $1.07 \pm 0.04$ & $0.81 \pm 0.07$ \\
\hline kinesin family member $1 \mathrm{~B}$ & Kif $1 b$ & $1.05 \pm 0.07$ & $1.28 \pm 0.11$ \\
\hline kinesin heavy chain family, member 2 & Kif2 & $0.97 \pm 0.01$ & $1.14 \pm 0.01$ \\
\hline tubulin, beta $2 \mathrm{~b}$ & Tubb2b & $0.93 \pm 0.06$ & $1.48 \pm 0.10$ \\
\hline katanin p60 (ATPase-containing) subunit A1 & Katna1 & $0.90 \pm 0.03$ & $0.86 \pm 0.13$ \\
\hline spastin (predicted) & Spast_predicted & $0.89 \pm 0.03$ & $1.50 \pm 0.10$ \\
\hline dynein-like protein 2 & DLP2 & $0.83 \pm 0.09$ & $0.26 \pm 0.04$ \\
\hline kinesin family member $3 a$ & Kif3a & $0.75 \pm 0.02$ & $0.38 \pm 0.10$ \\
\hline WD repeat domain 34 & Wdr34 & $0.73 \pm 0.02$ & $0.62 \pm 0.08$ \\
\hline NudC domain containing 2 & Nudcd2 & $0.72 \pm 0.05$ & $0.55 \pm 0.03$ \\
\hline similar to hypothetical protein FLJ1030 (predicted) & RGD1306493_predi cted & $0.70 \pm 0.04$ & $0.35 \pm 0.08$ \\
\hline tubulin tyrosine ligase & $\mathrm{Ttl}$ & $0.70 \pm 0.01$ & $0.66 \pm 0.05$ \\
\hline kinesin family member $\mathrm{C} 2$ & KIFC2 & $0.69 \pm 0.03$ & $0.33 \pm 0.05$ \\
\hline BPY2 interacting protein 1 (predicted) & Bpy2ip1_predicted & $0.67 \pm 0.08$ & $0.43 \pm 0.09$ \\
\hline restin (Reed-Steinberg cell-expressed intermediate & Rsn & $0.61 \pm 0.07$ & $0.91 \pm 0.12$ \\
\hline
\end{tabular}




\begin{tabular}{|c|c|c|c|}
\hline Gene Name & Gene Symbol & $\begin{array}{c}\text { IMCD-Signal } \\
\text { Mean } \pm \text { SE }\end{array}$ & $\begin{array}{c}\text { non-IMCD-Signal } \\
\text { Mean } \pm \text { SE }\end{array}$ \\
\hline $\begin{array}{l}\text { adenomatosis polyposis coli } \\
\text { tubulin, gamma complex associated protein } 6 \\
\text { (predicted) } \\
\text { MAP/microtubule affinity-regulating kinase } 1 \\
\text { dynamin } 3 \\
\text { tubulin, gamma complex associated protein } 3 \\
\text { tubulin, beta } 6 \\
\text { double cortin and calcium/calmodulin-dependent } \\
\text { protein kinase-like } 1 \\
\text { similar to hypothetical protein FLJ32871 } \\
\text { tubulin, beta } 4 \\
\text { tubulin, epsilon } 1 \text { (predicted) } \\
\text { pleckstrin homology-like domain, family B, member } 1 \\
\text { microtubule-associated protein, RP/EB family, } \\
\text { member } 3 \\
\text { dynein light chain roadblock-type } 2 \text { (predicted) } \\
\text { Unc- } 84 \text { homolog A (C. elegans) } \\
\text { protein regulator of cytokinesis } 1 \text { (predicted) } \\
\text { similar to RIKEN cDNA } 6330415 \mathrm{M} 09 \text { (predicted) } \\
\text { kinesin family member } 13 \text { A (predicted) } \\
\text { kinesin family member } 15 \\
\text { dynamin } 2 \\
\text { kinesin family member } 11 \\
\text { kinesin light chain } 3 \\
\text { kinesin family member } 23 \text { (predicted) } \\
\text { Katanin p60 subunit A-like } 1 \\
\text { kinesin family member C1 } \\
\text { dynein cytoplasmic } 1 \text { light intermediate chain } 1 \\
\text { kinesin family member } 22 \\
\text { microtubule-associated protein tau }\end{array}$ & $\begin{array}{l}\text { Apc } \\
\text { Tubgcp6_predicted } \\
\text { Mark1 } \\
\text { Dnm3 } \\
\text { Tubgcp3 } \\
\text { Tubb6 } \\
\text { Dcamk11 } \\
\\
\text { RGD1307081 } \\
\text { Tubb4 } \\
\text { Tube1_predicted } \\
\text { Phldb1 } \\
\text { Mapre3 } \\
\text { Dynlrb2_predicted } \\
\text { Unc84a } \\
\text { Prc1_predicted } \\
\text { RGD1308384_predi cted } \\
\text { Kif13a_predicted } \\
\text { Kif15 } \\
\text { Dnm2 } \\
\text { Kif11 } \\
\text { Klc3 } \\
\text { Kif23_predicted } \\
\text { Katnal1 } \\
\text { Kifc1 } \\
\text { Dync1li1 } \\
\text { Kif22 } \\
\text { Mapt }\end{array}$ & $\begin{array}{c}0.57 \pm 0.04 \\
0.49 \pm 0.03 \\
\\
0.47 \pm 0.02 \\
0.45 \pm 0.01 \\
0.44 \pm 0.02 \\
0.42 \pm 0.06 \\
0.38 \pm 0.09 \\
\\
0.36 \pm 0.07 \\
0.35 \pm 0.02 \\
0.34 \pm 0.06 \\
0.32 \pm 0.05 \\
0.30 \pm 0.02 \\
\\
0.29 \pm 0.01 \\
0.28 \pm 0.01 \\
0.26 \pm 0.04 \\
0.26 \pm 0.03 \\
0.26 \pm 0.02 \\
0.22 \pm 0.03 \\
0.21 \pm 0.01 \\
0.20 \pm 0.02 \\
0.18 \pm 0.01 \\
0.16 \pm 0.05 \\
0.15 \pm 0.02 \\
0.07 \pm 0.02 \\
0.05 \pm 0.0 \\
-0.03 \pm 0.02 \\
-0.15 \pm 0.01\end{array}$ & $\begin{array}{l}0.32 \pm 0.05 \\
0.63 \pm 0.15 \\
\\
0.19 \pm 0.03 \\
0.45 \pm 0.03 \\
0.27 \pm 0.02 \\
1.25 \pm 0.10 \\
0.32 \pm 0.08 \\
\\
0.32 \pm 0.04 \\
0.18 \pm 0.07 \\
0.32 \pm 0.03 \\
0.85 \pm 0.23 \\
0.55 \pm 0.09 \\
\\
0.16 \pm 0.02 \\
0.65 \pm 0.07 \\
0.70 \pm 0.05 \\
0.77 \pm 0.03 \\
0.20 \pm 0.03 \\
0.31 \pm 0.07 \\
0.65 \pm 0.05 \\
0.27 \pm 0.03 \\
0.40 \pm 0.11 \\
0.44 \pm 0.08 \\
0.15 \pm 0.04 \\
0.48 \pm 0.04 \\
0.22 \pm 0.06 \\
0.66 \pm 0.06 \\
0.78 \pm 0.06\end{array}$ \\
\hline $\begin{array}{l}\text { Gene Name } \\
\text { keratin complex 1, acidic, gene } 18 \\
\text { keratin complex 2, basic, gene } 8 \\
\text { lamin A } \\
\text { plakophilin } 4 \text { (predicted) } \\
\text { keratin complex 1, acidic, gene } 19 \\
\text { plakophilin 2 } \\
\text { keratin complex 2, basic, gene } 7 \\
\text { Desmuslin } \\
\text { plakophilin } 3 \text { (predicted) } \\
\text { lamin B1 } \\
\text { plakophilin } 1 \text { (predicted) } \\
\text { beaded filament structural protein } 1 \\
\text { Nestin } \\
\text { peripherin } 1 \\
\text { desmin } \\
\text { envoplakin (predicted) } \\
\text { vimentin }\end{array}$ & $\begin{array}{l}\text { Gene Symbol } \\
\text { Krt1-18 } \\
\text { Krt2-8 } \\
\text { Lmna } \\
\text { Pkp4_predicted } \\
\text { Krt1-19 } \\
\text { Pkp2 } \\
\text { Krt2-7 } \\
\text { Dmn } \\
\text { Pkp3_predicted } \\
\text { Lmnb1 } \\
\text { Pkp1_predicted } \\
\text { Bfsp1 } \\
\text { Nes } \\
\text { Prph1 } \\
\text { Des } \\
\text { Evpl_predicted } \\
\text { Vim }\end{array}$ & $\begin{array}{c}\text { IMCD-Signal } \\
\text { Mean } \pm \text { SE } \\
25.16 \pm 0.62 \\
18.28 \pm 0.19 \\
7.11 \pm 0.47 \\
5.65 \pm 0.63 \\
4.98 \pm 0.50 \\
1.54 \pm 0.04 \\
1.49 \pm 0.31 \\
1.42 \pm 0.15 \\
0.80 \pm 0.02 \\
0.48 \pm 0.09 \\
0.31 \pm 0.06 \\
0.21 \pm 0.01 \\
0.15 \pm 0.02 \\
0.10 \pm 0.01 \\
0.08 \pm 0.06 \\
-0.51 \pm 0.03 \\
-4.23 \pm 0.11\end{array}$ & $\begin{array}{c}\text { non-IMCD-Signal } \\
\text { Mean } \pm \text { SE } \\
7.99 \pm 0.30 \\
3.91 \pm 0.59 \\
1.32 \pm 0.14 \\
4.12 \pm 0.27 \\
-0.34 \pm 0.18 \\
1.53 \pm 0.14 \\
12.10 \pm 0.54 \\
0.36 \pm 0.18 \\
0.57 \pm 0.08 \\
0.11 \pm 0.10 \\
0.53 \pm 0.03 \\
0.11 \pm 0.01 \\
0.94 \pm 0.05 \\
0.21 \pm 0.04 \\
0.41 \pm 0.07 \\
4.43 \pm 0.12 \\
24.68 \pm 0.50\end{array}$ \\
\hline
\end{tabular}




\section{Transporters and channels}

Table 13

Table 13A. Water channels.

Table 13B. Ion channels and transporters excluding SLC proteins.

Table 13C. Solute carrier proteins (SLCs).

\begin{tabular}{|c|c|c|c|}
\hline Gene Name & Gene Symbol & $\begin{array}{l}\text { IMCD-Signal } \\
\text { Mean } \pm \text { SE }\end{array}$ & $\begin{array}{l}\text { non-IMCD-Signal } \\
\quad \text { Mean } \pm \text { SE }\end{array}$ \\
\hline $\begin{array}{l}\text { aquaporin } 4 \\
\text { aquaporin } 2 \\
\text { aquaporin } 3 \\
\text { aquaporin } 1\end{array}$ & $\begin{array}{l}\text { Aqp4 } \\
\text { Aqp2 } \\
\text { Aqp3 } \\
\text { Aqp1 }\end{array}$ & $\begin{array}{l}68.09 \pm 0.98 \\
59.01 \pm 1.67 \\
58.08 \pm 3.95 \\
-9.62 \pm 2.09\end{array}$ & $\begin{array}{c}5.77 \pm 6.48 \\
32.22 \pm 7.6 \\
3.87 \pm 2.74 \\
58.23 \pm 14.91\end{array}$ \\
\hline Gene Name & Gene Symbol & $\begin{array}{l}\text { IMCD-Signal } \\
\text { Mean } \pm \text { SE }\end{array}$ & $\begin{array}{l}\text { non-IMCD-Signal } \\
\text { Mean } \pm \text { SE }\end{array}$ \\
\hline ATPase, $\mathrm{Na}+\mathrm{K}+$ transporting, beta 1 polypeptide & Atp1b1 & $56.73 \pm 0.84$ & $33.13 \pm 2.26$ \\
\hline ATPase, $\mathrm{Na}+\mathrm{K}+$ transporting, alpha 1 polypeptide & Atp1a1 & $34.84 \pm 0.50$ & $11.43 \pm 0.27$ \\
\hline chloride intracellular channel 1 & Clic1 & $23.54 \pm 0.39$ & $18.78 \pm 0.96$ \\
\hline ATPase, $\mathrm{H}$ transporting, lysosomal V0 subunit c & Atp6v0c & $18.38 \pm 0.32$ & $15.65 \pm 0.82$ \\
\hline ATPase, $\mathrm{H}+$ transporting, V0 subunit $\mathrm{E}$ isoform 1 & Atp6v0e1 & $16.72 \pm 0.04$ & $8.6 \pm 1.46$ \\
\hline ATPase, $\mathrm{Na}+\mathrm{K}+$ transporting, beta 3 polypeptide & Atp1b3 & $13.60 \pm 0.51$ & $18.79 \pm 0.83$ \\
\hline ATPase, $\mathrm{H}$ transporting, lysosomal V1 subunit $\mathrm{F}$ & Atp6v1f & $13.51 \pm 0.42$ & $6.65 \pm 0.50$ \\
\hline chloride channel calcium activated 6 & Clca6 & $13.03 \pm 1.51$ & $-3.14 \pm 0.33$ \\
\hline ATPase, $\mathrm{H}+$ transporting, $\mathrm{V} 1$ subunit $\mathrm{D}$ & Atp6v1d & $12.11 \pm 0.19$ & $5.17 \pm 0.29$ \\
\hline inositol 1,4,5-triphosphate receptor 1 & Itpr1 & $12.02 \pm 0.68$ & $1.23 \pm 0.39$ \\
\hline ATPase, $\mathrm{Ca}++$ transporting, cardiac muscle, slow twitch 2 & Atp2a2 & $11.79 \pm 0.13$ & $6.37 \pm 0.54$ \\
\hline ATPase, $\mathrm{H}+$ transporting, lysosomal accessory protein 1 & Atp6ap1 & $11.09 \pm 0.61$ & $10.44 \pm 1.01$ \\
\hline ATPase, $\mathrm{H}+$ transporting, V1 subunit $\mathrm{E}$ isoform 1 & Atp6vle1 & $8.58 \pm 0.50$ & $3.27 \pm 0.26$ \\
\hline ATP-binding cassette, sub-family G (WHITE), member 1 & Abcg1 & $7.12 \pm 0.34$ & $3.75 \pm 0.36$ \\
\hline sodium channel, nonvoltage-gated 1 gamma & Scnn1g & $6.63 \pm 0.58$ & $-1.33 \pm 0.31$ \\
\hline ATPase, $\mathrm{H}+$ transporting, V0 subunit D isoform 1 & Atp6v0d1 & $6.18 \pm 0.22$ & $5.88 \pm 0.56$ \\
\hline ATPase, $\mathrm{H}$ transporting, lysosomal V1 subunit G3 (predicted) & Atp6v1g3_predicted & $6.10 \pm 1.32$ & $0.94 \pm 0.41$ \\
\hline ATPase, $\mathrm{H}$ transporting, lysosomal V1 subunit G1 (predicted) & Atp6v1g1_predicted & $5.70 \pm 0.34$ & $1.89 \pm 0.04$ \\
\hline $\begin{array}{l}\text { potassium channel tetramerisation domain containing } 12 \\
\text { (predicted) }\end{array}$ & Kctd12_predicted & $5.64 \pm 0.19$ & $4.09 \pm 0.92$ \\
\hline vacuolar ATPase subunit $\mathrm{H}$ & Atp6v1h & $5.54 \pm 0.05$ & $2.51 \pm 0.24$ \\
\hline ATPase, $\mathrm{Ca}++$-sequestering & Atp2c1 & $5.32 \pm 0.06$ & $2.23 \pm 0.17$ \\
\hline $\begin{array}{l}\text { potassium channel tetramerisation domain containing } 14 \\
\text { (predicted) }\end{array}$ & Kctd14_predicted & $4.94 \pm 0.19$ & $-0.42 \pm 0.12$ \\
\hline chloride channel 3 & Clcn3 & $4.76 \pm 0.14$ & $3.43 \pm 0.22$ \\
\hline ATPase, $\mathrm{H}+$ transporting, $\mathrm{V} 1$ subunit $\mathrm{C}$, isoform 1 & Atp6v1c1 & $4.18 \pm 0.05$ & $3.38 \pm 0.44$ \\
\hline potassium channel, subfamily $\mathrm{K}$, member 1 & Kcnk1 & $4.03 \pm 0.15$ & $0.40 \pm 0.27$ \\
\hline ATPase, Class I, type 8B, member 1 (predicted) & Atp8b1_predicted & $3.97 \pm 0.27$ & $1.08 \pm 0.33$ \\
\hline tweety homolog 3 (Drosophila) (predicted) & Ttyh3_predicted & $3.90 \pm 0.36$ & $1.49 \pm 0.25$ \\
\hline transmembrane 9 superfamily member 1 & Tm9sf1 & $3.73 \pm 0.08$ & $3.68 \pm 0.10$ \\
\hline ATPase, $\mathrm{H}+$ transporting, V0 subunit B (predicted) & Atp6v0b_predicted & $3.66 \pm 0.03$ & $4.32 \pm 0.22$ \\
\hline ATPase, $\mathrm{H}+$ transporting, V0 subunit $\mathrm{E}$ isoform 2 & Atp6r0e 2 & $3.64 \pm 0.27$ & $2.61 \pm 0.40$ \\
\hline ATP-binding cassette, sub-family B (MDR/TAP), member 10 & Abcb10 & $3.51 \pm 0.14$ & $1.26 \pm 0.09$ \\
\hline ATP-binding cassette, sub-family D (ALD), member 3 & Abcd3 & $3.25 \pm 0.01$ & $1.51 \pm 0.2$ \\
\hline chloride channel, nucleotide-sensitive, $1 \mathrm{~A}$ & Clns1a & $3.16 \pm 0.13$ & $1.93 \pm 0.16$ \\
\hline inositol 1,4,5-triphosphate receptor 3 & Itpr3 & $3.14 \pm 0.05$ & $0.3 \pm 0.10$ \\
\hline $\begin{array}{l}\text { potassium voltage-gated channel, Isk-related subfamily, } \\
\text { member } 3\end{array}$ & Kcne3 & $3.11 \pm 0.1$ & $-0.46 \pm 0.08$ \\
\hline ATP-binding cassette, sub-family C (CFTR/MRP), member 4 & Abcc4 & $3.07 \pm 0.07$ & $5.52 \pm 0.43$ \\
\hline $\begin{array}{l}\text { transient receptor potential cation channel, subfamily V, } \\
\text { member } 4\end{array}$ & Trpv4 & $3.02 \pm 0.21$ & $0.9 \pm 0.12$ \\
\hline ATPase, $\mathrm{H}$ transporting, lysosomal V1 subunit B2 & Atp6v1b2 & $3 \pm 0.13$ & $1.88 \pm 0.24$ \\
\hline chloride channel $\mathrm{Kb}$ & Clenkb & $2.93 \pm 0.72$ & $0.22 \pm 0.20$ \\
\hline $\begin{array}{l}\text { ATPase, H+ transporting, lysosomal V0 subunit A isoform } 4 \\
\text { (predicted) }\end{array}$ & Atp6v0a4_predicted & $2.74 \pm 0.28$ & $0.17 \pm 0.06$ \\
\hline ATP-binding cassette, sub-family C (CFTR/MRP), member 5 & Abcc5 & $2.69 \pm 0.24$ & $1.12 \pm 0.07$ \\
\hline arsA arsenite transporter, ATP-binding, homolog 1 (bacterial) & Asna1 & $2.4 \pm 0.04$ & $0.85 \pm 0.06$ \\
\hline Kv channel interacting protein 4 & Kcnip4 & $2.37 \pm 0.31$ & $-0.17 \pm 0.16$ \\
\hline ATPase, $\mathrm{Ca}++$ transporting, plasma membrane 1 & Atp2b1 & $2.32 \pm 0.2$ & $4.71 \pm 0.36$ \\
\hline ATP-binding cassette, sub-family A (ABC1), member 2 & Abca2 & $2.26 \pm 0.03$ & $1.06 \pm 0.18$ \\
\hline Rhesus blood group-associated C glycoprotein & Rhcg & $2.16 \pm 0.11$ & $0.64 \pm 0.05$ \\
\hline transmembrane 9 superfamily protein member 4 & Tm9sf4 & $2.15 \pm 0.05$ & $1.00 \pm 0.21$ \\
\hline ATP-binding cassette, sub-family C (CFTR/MRP), member 1 & Abcc1 1 & $2.13 \pm 0.12$ & $2.12 \pm 0.08$ \\
\hline potassium voltage-gated channel, subfamily $Q$, member 1 & Kenq1 & $2.12 \pm 0.03$ & $-0.25 \pm 0.05$ \\
\hline $\begin{array}{l}\text { transient receptor potential cation channel, subfamily C, } \\
\text { member } 1\end{array}$ & Trpc1 & $2.08 \pm 0.09$ & $0.18 \pm 0.02$ \\
\hline $\begin{array}{l}\text { potassium channel tetramerisation domain containing } 5 \\
\text { (predicted) }\end{array}$ & Kctd5_predicted & $1.96 \pm 0.18$ & $1.28 \pm 0.34$ \\
\hline ATP-binding cassette, sub-family F (GCN20), member 3 & Abcf3 & $1.95 \pm 0.05$ & $1.45 \pm 0.09$ \\
\hline
\end{tabular}




\begin{tabular}{|c|c|c|c|}
\hline Gene Name & Gene Symbol & $\begin{array}{l}\text { IMCD-Signal } \\
\text { Mean } \pm \text { SE }\end{array}$ & $\begin{array}{l}\text { non-IMCD-Signal } \\
\quad \text { Mean } \pm \text { SE }\end{array}$ \\
\hline sodium channel, nonvoltage-gated 1 beta & Scnn $1 b$ & $1.94 \pm 0.23$ & $-0.14 \pm 0.11$ \\
\hline $\begin{array}{l}\text { ATP-binding cassette, sub-family F (GCN20), member } 2 \\
\text { (predicted) }\end{array}$ & Abcf2_predicted & $1.91 \pm 0.04$ & $1.60 \pm 0.14$ \\
\hline inositol 1,4,5-triphosphate receptor 2 & Itpr2 & $1.83 \pm 0.11$ & $0.39 \pm 0.03$ \\
\hline ATP-binding cassette, sub-family A (ABC1), member 3 & Abca3 & $1.81 \pm 0.08$ & $2.50 \pm 0.10$ \\
\hline ATPase type $13 \mathrm{~A} 1$ (predicted) & Atp13a1_predicted & $1.55 \pm 0.24$ & $2.13 \pm 0.34$ \\
\hline transporter 1, ATP-binding cassette, sub-family B (MDR/TAP) & Tap1 $-\mathrm{P}$ (1) & $1.55 \pm 0.04$ & $1.06 \pm 0.07$ \\
\hline $\begin{array}{l}\text { potassium channel tetramerisation domain containing } 6 \\
\text { (predicted) }\end{array}$ & Kctd6_predicted & $1.52 \pm 0.21$ & $0.62 \pm 0.08$ \\
\hline $\begin{array}{l}\text { potassium channel tetramerisation domain containing } 9 \\
\text { (predicted) }\end{array}$ & Kctd9_predicted & $1.51 \pm 0.01$ & $0.81 \pm 0.17$ \\
\hline ATPase, $\mathrm{H}+$ transporting, $\mathrm{V} 1$ subunit $\mathrm{C}$, isoform 2 & Atp6v1c2 & $1.5 \pm 0.05$ & $0.50 \pm 0.13$ \\
\hline chloride intracellular channel 3 & Clic3 & $1.3 \pm 0.08$ & $-0.23 \pm 0.03$ \\
\hline ATPase type 13A2 (predicted) & Atp13a2_predicted & $1.17 \pm 0.14$ & $2.24 \pm 0.15$ \\
\hline similar to potassium channel TASK2 & LOC 364241 & $1.08 \pm 0.01$ & $1.26 \pm 0.04$ \\
\hline $\begin{array}{l}\text { ATPase, H+ transporting, lysosomal V0 subunit a isoform } 2 \\
\text { (predicted) }\end{array}$ & Atp6v0a2_predicted & $1 \pm 0.02$ & $1.01 \pm 0.09$ \\
\hline ATP-binding cassette, sub-family A (ABC1), member 7 & Abca7 & $1 \pm 0.1$ & $0.95 \pm 0.2$ \\
\hline transient receptor potential-related protein, ChaK & Trpm7 & $0.99 \pm 0.07$ & $0.95 \pm 0.06$ \\
\hline purinergic receptor $\mathrm{P} 2 \mathrm{X}$, ligand-gated ion channel 4 & $\mathrm{P} 2 \mathrm{rx} 4$ & $0.99 \pm 0.13$ & $1.75 \pm 0.23$ \\
\hline ATP-binding cassette, sub-family A (ABC1), member 5 & Abca5 & $0.99 \pm 0.02$ & $0.33 \pm 0.07$ \\
\hline similar to sodium/calcium exchanger protein & LOC498185 & $0.91 \pm 0.19$ & $1.48 \pm 0.24$ \\
\hline gamma-aminobutyric acid A receptor, pi & Gabrp & $0.83 \pm 0.11$ & $-0.22 \pm 0.05$ \\
\hline $\begin{array}{l}\text { potassium inwardly-rectifying channel, subfamily J, member } \\
16\end{array}$ & Kcnj16 & $0.82 \pm 0.02$ & $1.67 \pm 0.15$ \\
\hline two pore channel 1 & Tpen1 & $0.80 \pm 0.16$ & $5.71 \pm 0.12$ \\
\hline mucolipin 1 (predicted) & Mcoln1_predicted & $0.76 \pm 0.08$ & $1.04 \pm 0.16$ \\
\hline glutamate receptor, ionotropic, kainate 5 & Grik5 $-\mathrm{r}-2$ & $0.74 \pm 0.07$ & $0.12 \pm 0.01$ \\
\hline calcium channel, voltage-dependent, beta 3 subunit & Cacnb3 & $0.73 \pm 0.03$ & $0.16 \pm 0.01$ \\
\hline transporter 2, ATP-binding cassette, sub-family B (MDR/TAP) & Tap2 & $0.71 \pm 0.07$ & $0.37 \pm 0.09$ \\
\hline $\begin{array}{l}\text { ATPase, aminophospholipid transporter (APLT), class I, type } \\
\text { 8A, member } 1 \text { (predicted) }\end{array}$ & Atp8a1_predicted & $0.71 \pm 0.03$ & $0.52 \pm 0.04$ \\
\hline chloride channel calcium activated 3 (predicted) & Clca3_predicted & $0.68 \pm 0.09$ & $-0.04 \pm 0.01$ \\
\hline glutamate receptor, ionotropic, kainate 2 & Grik2 & $0.67 \pm 0.21$ & $-0.02 \pm 0.02$ \\
\hline ATPase, $\mathrm{H}$ transporting, lysosomal V1 subunit B1 (predicted) & Atp6v1b1_predicted & $0.67 \pm 0.06$ & $0.03 \pm 0.16$ \\
\hline $\begin{array}{l}\text { hyperpolarization activated cyclic nucleotide-gated potassium } \\
\text { channel } 2\end{array}$ & $\mathrm{Hen} 2$ & $0.66 \pm 0.01$ & $0.28 \pm 0.11$ \\
\hline ATP-binding cassette, sub-family A ( $\mathrm{ABC} 1)$, member 1 & Abcal & $0.63 \pm 0.10$ & $1.09 \pm 0.26$ \\
\hline cholinergic receptor, nicotinic, beta polypeptide 1 (muscle) & Chrnb1 & $0.60 \pm 0.02$ & $0.48 \pm 0.08$ \\
\hline ATPase, $\mathrm{H}+$ transporting, lysosomal V0 subunit A1 & Atp6v0a1 & $0.60 \pm 0.04$ & $0.69 \pm 0.06$ \\
\hline sodium channel, nonvoltage-gated 1 alpha & Scnn1a & $0.58 \pm 0.03$ & $0.02 \pm 0.03$ \\
\hline potassium channel, subfamily K, member 6 & Kcnk6 & $0.57 \pm 0.05$ & $0.23 \pm 0.05$ \\
\hline ATP-binding cassette, sub-family B (MDR/TAP), member 6 & Abcb6 & $0.54 \pm 0.05$ & $0.25 \pm 0.07$ \\
\hline chloride intracellular channel 4 & Clic4 & $0.54 \pm 0.09$ & $1.47 \pm 0.43$ \\
\hline chloride intracellular channel 2 & Clic2 & $0.5 \pm 0.10$ & $7.03 \pm 0.87$ \\
\hline $\begin{array}{l}\text { potassium voltage-gated channel, subfamily H (eag-related), } \\
\text { member } 3\end{array}$ & Kenh3 & $0.47 \pm 0.03$ & $0.52 \pm 0.15$ \\
\hline $\begin{array}{l}\text { potassium channel tetramerisation domain containing } 11 \\
\text { (predicted) }\end{array}$ & Kctd11_predicted & $0.47 \pm 0.10$ & $0.24 \pm 0.11$ \\
\hline ATP-binding cassette, sub-family D (ALD), member 4 & Abcd4 & $0.46 \pm 0.01$ & $0.45 \pm 0.06$ \\
\hline ATP-binding cassette, sub-family G (WHITE), member 3 & Abcg3 & $0.46 \pm 0.04$ & $0.40 \pm 0.07$ \\
\hline $\begin{array}{l}\text { transient receptor potential cation channel, subfamily M, } \\
\text { member } 4\end{array}$ & Trpm4 & $0.41 \pm 0.11$ & $0.41 \pm 0.11$ \\
\hline
\end{tabular}

\begin{tabular}{|c|c|c|c|}
\hline Gene Name & Gene Symbol & $\begin{array}{l}\text { IMCD-Signal } \\
\text { Mean } \pm \text { SE }\end{array}$ & $\begin{array}{l}\text { non-IMCD-Signal } \\
\text { Mean } \pm \text { SE }\end{array}$ \\
\hline solute carrier family 14 (urea transporter), member 2 & Slc14a2 & $39.31 \pm 0.15$ & $20.34 \pm 3.51$ \\
\hline solute carrier family 5 (inositol transporters), member 3 & Slc5a3 & $23.46 \pm 1.13$ & $12.07 \pm 0.57$ \\
\hline solute carrier family 19 (thiamine transporter), member 2 & Slc19a2 & $13.95 \pm 0.2$ & $-0.67 \pm 0.17$ \\
\hline solute carrier family 2 (facilitated glucose transporter), member & Slc2a1 & $11.38 \pm 0.4$ & $3.3 \pm 0.21$ \\
\hline $\begin{array}{l}\text { solute carrier family } 7 \text { (cationic amino acid transporter, y+ } \\
\text { system), member } 1\end{array}$ & Slc7a1 & $10.59 \pm 0.1$ & $-0.26 \pm 0.04$ \\
\hline solute carrier organic anion transporter family, member $4 \mathrm{a} 1$ & Slco4a1 & $8.86 \pm 0.58$ & $15.9 \pm 1.88$ \\
\hline $\begin{array}{l}\text { solute carrier family } 11 \text { (proton-coupled divalent metal ion } \\
\text { transporters), member } 2\end{array}$ & Slc11a2 & $8.71 \pm 0.88$ & $-0.65 \pm 0.19$ \\
\hline solute carrier family 35 , member B3 (predicted) & Slc35b3_predicted & $6.5 \pm 0.18$ & $2.4 \pm 0.29$ \\
\hline solute carrier family 4 , member 1 & Slc4a1 & $6.22 \pm 1.37$ & $1.14 \pm 0.72$ \\
\hline $\begin{array}{l}\text { solute carrier family } 6 \text { (neurotransmitter transporter), member } \\
17\end{array}$ & Slc6a17 & $5.98 \pm 0.78$ & $-0.5 \pm 0.28$ \\
\hline $\begin{array}{l}\text { solute carrier family } 4 \text {, sodium bicarbonate transporter-like, } \\
\text { member } 11 \text { (predicted) }\end{array}$ & Slc4a11_predicted & $5.8 \pm 0.57$ & $16.44 \pm 2.35$ \\
\hline solute carrier family 44, member 2 (predicted) & Slc44a2_predicted & $4.68 \pm 0.20$ & $3.85 \pm 0.15$ \\
\hline
\end{tabular}




\begin{tabular}{|c|c|c|c|}
\hline Gene Name & Gene Symbol & $\begin{array}{l}\text { IMCD-Signal } \\
\text { Mean } \pm \text { SE }\end{array}$ & $\begin{array}{l}\text { non-IMCD-Signal } \\
\quad \text { Mean } \pm \text { SE }\end{array}$ \\
\hline $\begin{array}{l}\text { solute carrier family } 9 \text { (sodium/hydrogen exchanger), member } \\
6 \text { (predicted) }\end{array}$ & Slc9a6_predicted & $4.65 \pm 0.18$ & $1.2 \pm 0.12$ \\
\hline solute carrier family 9, member 4 & Slc9a4 & $4.25 \pm 0.25$ & $-1.16 \pm 0.12$ \\
\hline solute carrier family 25 , member 1 & Slc25a1 & $4.11 \pm 0.05$ & $0.8 \pm 0.06$ \\
\hline $\begin{array}{l}\text { solute carrier family } 35 \text { (CMP-sialic acid transporter), member } \\
1 \text { (predicted) }\end{array}$ & Slc35a1_predicted & $3.68 \pm 0.16$ & $0.64 \pm 0.16$ \\
\hline solute carrier family 20 (phosphate transporter), member 1 & Slc20a1 & $3.25 \pm 0.24$ & $9.84 \pm 0.39$ \\
\hline $\begin{array}{l}\text { solute carrier family } 22 \text { (organic cation transporter), member } \\
18\end{array}$ & Slc22a 18 & $3.05 \pm 0.1$ & $0.05 \pm 0.04$ \\
\hline $\begin{array}{l}\text { solute carrier family } 39 \text { (zinc transporter), member } 10 \\
\text { (predicted) }\end{array}$ & Slc39a10_predicted & $2.91 \pm 0.07$ & $1.74 \pm 0.26$ \\
\hline solute carrier family 31 , member 2 & Slc31a2 & $2.73 \pm 0.14$ & $12.5 \pm 2.12$ \\
\hline $\begin{array}{l}\text { solute carrier family } 9 \text { (sodium/hydrogen exchanger), isoform } \\
3 \text { regulator } 1\end{array}$ & Slc9a3r1 & $2.68 \pm 0.15$ & $3.37 \pm 0.69$ \\
\hline solute carrier family 12, member 2 & Slc12a2 & $2.64 \pm 0.4$ & $4.95 \pm 0.23$ \\
\hline $\begin{array}{l}\text { solute carrier family } 16 \text { (monocarboxylic acid transporters), } \\
\text { member } 3\end{array}$ & Slc16a3 & $2.42 \pm 0.06$ & $0.46 \pm 0.13$ \\
\hline solute carrier family 33 (acetyl-CoA transporter), member 1 & Slc33a1 & $2.41 \pm 0.02$ & $2.38 \pm 0.26$ \\
\hline $\begin{array}{l}\text { solute carrier family } 16 \text { (monocarboxylic acid transporters), } \\
\text { member } 1\end{array}$ & Slc16a1 & $2.32 \pm 0.05$ & $0.46 \pm 0.04$ \\
\hline $\begin{array}{l}\text { solute carrier family } 37 \text { (glycerol-3-phosphate transporter), } \\
\text { member } 1\end{array}$ & Slc37a1 & $2.23 \pm 0.08$ & $1.09 \pm 0.15$ \\
\hline solute carrier family 4 , member 2 & Slc4a2 & $2.17 \pm 0.02$ & $1.63 \pm 0.17$ \\
\hline solute carrier family 39 (zinc transporter), member 13 & Slc39a13 & $2.09 \pm 0.11$ & $2.32 \pm 0.07$ \\
\hline $\begin{array}{l}\text { solute carrier family } 22 \text { (organic cation transporter), member } \\
17\end{array}$ & Slc22a17 & $1.8 \pm 0.49$ & $2.66 \pm 0.39$ \\
\hline solute carrier family 22 (organic cation transporter), member 5 & Slc22a5 & $1.75 \pm 0.08$ & $4.07 \pm 0.52$ \\
\hline $\begin{array}{l}\text { solute carrier family } 37 \text { (glycerol-6-phosphate transporter), } \\
\text { member } 4\end{array}$ & Slc37a4 & $1.7 \pm 0.09$ & $1.55 \pm 0.16$ \\
\hline $\begin{array}{l}\text { solute carrier family } 30 \text { (zinc transporter), member } 6 \\
\text { (predicted) }\end{array}$ & Slc30a6_predicted & $1.7 \pm 0.11$ & $1.19 \pm 0.1$ \\
\hline $\begin{array}{l}\text { solute carrier family } 30 \text { (zinc transporter), member } 5 \\
\text { (predicted) }\end{array}$ & Slc30a5_predicted & $1.64 \pm 0.14$ & $1.12 \pm 0.06$ \\
\hline solute carrier family 31 (copper transporters), member 1 & Slc31a1 & $1.6 \pm 0.09$ & $0.6 \pm 0.13$ \\
\hline $\begin{array}{l}\text { solute carrier family } 7 \text { (cationic amino acid transporter, y+ } \\
\text { system), member } 6 \text { (predicted) }\end{array}$ & Slc7a6_predicted & $1.58 \pm 0.08$ & $1.42 \pm 0.19$ \\
\hline solute carrier family 30 (zinc transporter), member 2 & Slc30a2 & $1.51 \pm 0.02$ & $0.01 \pm 0.05$ \\
\hline $\begin{array}{l}\text { solute carrier family } 5 \text { (sodium-dependent vitamin transporter), } \\
\text { member } 6\end{array}$ & Slc5a6 & $1.46 \pm 0.02$ & $2.96 \pm 0.14$ \\
\hline solute carrier family 27 (fatty acid transporter), member 4 & Slc27a4 & $1.39 \pm 0.13$ & $1.07 \pm 0.26$ \\
\hline solute carrier family 17 (anion/sugar transporter), member 5 & Slc17a5 & $1.37 \pm 0.15$ & $1.49 \pm 0.05$ \\
\hline $\begin{array}{l}\text { solute carrier family } 7 \text { (cationic amino acid transporter, y+ } \\
\text { system), member } 8\end{array}$ & Slc7a8 & $1.35 \pm 0.03$ & $0.16 \pm 0.13$ \\
\hline $\begin{array}{l}\text { solute carrier family } 7 \text {, (cationic amino acid transporter, y+ } \\
\text { system) member } 13\end{array}$ & Slc7a13 & $1.26 \pm 0.07$ & $0.57 \pm 0.15$ \\
\hline solute carrier family 26 (sulfate transporter), member 1 & Slc26a1 & $1.24 \pm 0.06$ & $2.42 \pm 0.06$ \\
\hline $\begin{array}{l}\text { solute carrier family } 4 \text { (anion exchanger), member } 1 \text {, adaptor } \\
\text { protein (predicted) }\end{array}$ & Slc4a1ap_predicted & $1.23 \pm 0.08$ & $0.98 \pm 0.14$ \\
\hline solute carrier family 30 (zinc transporter), member 1 & Slc30a1 & $1.21 \pm 0.11$ & $0.25 \pm 0.06$ \\
\hline solute carrier family 35 , member $\mathrm{A} 4$ & Slc35a4 & $1.19 \pm 0.04$ & $1.06 \pm 0.08$ \\
\hline solute carrier family 35 (UDP-N-acetylglucosamine (UDP- & Slc35a3 & $1.18 \pm 0.04$ & $0.1 \pm 0.15$ \\
\hline $\begin{array}{l}\text { GlcNAc) transporter), member } 3 \\
\text { solute carrier family } 35 \text {, member B4 (predicted) }\end{array}$ & Slc35b4 predicted & $1.17 \pm 0.05$ & $1.4 \pm 0.03$ \\
\hline solute carrier family 9 , member 1 & $\begin{array}{l}\text { SIscsob4_predicled } \\
\text { Slc9a1 }\end{array}$ & $\begin{array}{l}1.17 \pm 0.03 \\
1.15 \pm 0.06\end{array}$ & $\begin{array}{l}1.4 \pm 0.03 \\
0.77 \pm 0.02\end{array}$ \\
\hline $\begin{array}{l}\text { solute carrier family } 6 \text { (neurotransmitter transporter, betaine/ } \\
\text { GABA), member } 12\end{array}$ & Slc6a12 & $1.14 \pm 0.05$ & $2.86 \pm 0.18$ \\
\hline solute carrier family 35 , member $\mathrm{C} 1$ (predicted) & Slc35c1_predicted & $1.12 \pm 0.05$ & $0.9 \pm 0.07$ \\
\hline solute carrier family 39 (metal ion transporter), member 6 & Slc39a6 & $1.1 \pm 0.03$ & $1.37 \pm 0.22$ \\
\hline solute carrier family 34 (sodium phosphate), member 1 & Slc34a1 & $1.02 \pm 0.09$ & $1.42 \pm 0.28$ \\
\hline solute carrier family 12 , member 1 & Slc12a1 & $1.01 \pm 0.34$ & $3.15 \pm 0.42$ \\
\hline solute carrier family 4 , member 3 & Slc4a3 & $1 \pm 0.04$ & $0.31 \pm 0.06$ \\
\hline $\begin{array}{l}\text { solute carrier family } 6 \text { (neurotransmitter transporter, creatine), } \\
\text { member } 8\end{array}$ & Slc6a8 & $0.93 \pm 0.09$ & $0.82 \pm 0.11$ \\
\hline $\begin{array}{l}\text { solute carrier family } 12 \text { (potassium/chloride transporters), } \\
\text { member } 7\end{array}$ & Slc12a7 & $0.9 \pm 0.1$ & $3.49 \pm 0.07$ \\
\hline $\begin{array}{l}\text { solute carrier family } 4 \text {, sodium bicarbonate cotransporter, } \\
\text { member } 7\end{array}$ & Slc4a7 & $0.88 \pm 0.05$ & $0.65 \pm 0.13$ \\
\hline solute carrier family 15 , member 4 & Slc15a4 & $0.88 \pm 0.09$ & $1.03 \pm 0.11$ \\
\hline $\begin{array}{l}\text { solute carrier family } 16 \text { (monocarboxylic acid transporters), } \\
\text { member } 10\end{array}$ & Slc16a10 & $0.87 \pm 0.05$ & $0.33 \pm 0.04$ \\
\hline solute carrier family 20, member 2 & Slc20a2 & $0.86 \pm 0.07$ & $0.75 \pm 0.11$ \\
\hline solute carrier family 22 (organic cation transporter), member & Slc22a15_predicted & $0.83 \pm 0.03$ & $1.27 \pm 0.12$ \\
\hline
\end{tabular}




\begin{tabular}{|c|c|c|c|}
\hline Gene Name & Gene Symbol & $\begin{array}{l}\text { IMCD-Signal } \\
\text { Mean } \pm \text { SE }\end{array}$ & $\begin{array}{l}\text { non-IMCD-Signal } \\
\quad \text { Mean } \pm \text { SE }\end{array}$ \\
\hline $\begin{array}{l}\text { solute carrier family } 16 \text { (monocarboxylic acid transporters), } \\
\text { member } 7\end{array}$ & Slc16a7 & $0.73 \pm 0.05$ & $1.47 \pm 0.12$ \\
\hline $\begin{array}{l}\text { solute carrier family } 9 \text { (sodium/hydrogen exchanger), member } \\
8\end{array}$ & Slc9a8 & $0.69 \pm 0.02$ & $0.44 \pm 0.07$ \\
\hline $\begin{array}{l}\text { solute carrier family } 2 \text {, (facilitated glucose transporter) member } \\
8\end{array}$ & Slc2a8 & $0.65 \pm 0.07$ & $0.55 \pm 0.12$ \\
\hline solute carrier family 4 (anion exchanger), member 8 & Slc4a8 & $0.65 \pm 0.02$ & $0.69 \pm 0.05$ \\
\hline $\begin{array}{l}\text { solute carrier family } 1 \text { (neutral amino acid transporter), member } \\
5\end{array}$ & Slc1a5 & $0.61 \pm 0.08$ & $1.89 \pm 0.37$ \\
\hline $\begin{array}{l}\text { solute carrier family } 12 \text { (potassium/chloride transporters), } \\
\text { member } 9\end{array}$ & Slc12a9 & $0.6 \pm 0.02$ & $0.6 \pm 0.07$ \\
\hline solute carrier family 23 (nucleobase transporters), member 2 & Slc23a2 & $0.58 \pm 0.01$ & $0.06 \pm 0.03$ \\
\hline $\begin{array}{l}\text { solute carrier family } 13 \text { (sodium-dependent dicarboxylate } \\
\text { transporter), member } 2\end{array}$ & Slc13a2 & $0.57 \pm 0.12$ & $0.17 \pm 0.07$ \\
\hline $\begin{array}{l}\text { solute carrier family } 9 \text { (sodium/hydrogen exchanger), member } \\
2\end{array}$ & Slc9a2 & $0.56 \pm 0.04$ & $-0.01 \pm 0.07$ \\
\hline solute carrier family $15(\mathrm{H}+$ /peptide transporter), member 2 & Slc15a2 & $0.53 \pm 0.03$ & $0.47 \pm 0.03$ \\
\hline solute carrier family 39 (zinc transporter), member 3 & Slc39a3 & $0.49 \pm 0.04$ & $0.41 \pm 0.08$ \\
\hline solute carrier family 30 (zinc transporter), member 7 & Slc30a7 & $0.46 \pm 0.02$ & $0.44 \pm 0.1$ \\
\hline solute carrier organic anion transporter family, member 3a1 & Slco3a1 & $0.46 \pm 0.06$ & $0.53 \pm 0.05$ \\
\hline $\begin{array}{l}\text { solute carrier family } 7 \text { (cationic amino acid transporter, y+ } \\
\text { system), member } 5\end{array}$ & Slc7a5 & $0.41 \pm 0.01$ & $0.31 \pm 0.11$ \\
\hline solute carrier family 35 , member D2 (predicted) & Slc35d2_predicted & $0.41 \pm 0.02$ & $0.28 \pm 0.03$ \\
\hline solute carrier family 5 (sodium iodide symporter), member 5 & Slc5a5 & $0.37 \pm 0.03$ & $0.01 \pm 0.01$ \\
\hline $\begin{array}{l}\text { solute carrier family } 24 \text { (sodium/potassium/calcium } \\
\text { exchanger), member } 2\end{array}$ & Slc24a2 & $0.36 \pm 0.01$ & $0.19 \pm 0.02$ \\
\hline solute carrier family 35 , member $\mathrm{C} 2$ & Slc35c2 & $0.34 \pm 0$ & $0.78 \pm 0.08$ \\
\hline solute carrier family 35 , member E4 & Slc35e4 & $0.32 \pm 0.02$ & $0.65 \pm 0.03$ \\
\hline solute carrier family 29 (nucleoside transporters), member 3 & $\mathrm{Slc} 29 \mathrm{a} 3$ & $0.32 \pm 0.02$ & $1.1 \pm 0.01$ \\
\hline solute carrier family 30 (zinc transporter), member 4 & Slc30a4 & $0.32 \pm 0.01$ & $2.22 \pm 0.17$ \\
\hline $\begin{array}{l}\text { solute carrier family } 1 \text { (glial high affinity glutamate } \\
\text { transporter), member } 3\end{array}$ & Slc1a3 & $0.25 \pm 0.01$ & $0.13 \pm 0.02$ \\
\hline $\begin{array}{l}\text { solute carrier family } 16 \text { (monocarboxylic acid transporters), } \\
\text { member } 6\end{array}$ & Slc16a6 & $0.24 \pm 0.05$ & $1.42 \pm 0.1$ \\
\hline $\begin{array}{l}\text { solute carrier family } 6 \text { (neurotransmitter transporter, taurine), } \\
\text { member } 6\end{array}$ & Slc6a6 & $0.24 \pm 0.02$ & $0.25 \pm 0.04$ \\
\hline solute carrier family 29 (nucleoside transporters), member 1 & Slc29a1 & $0.23 \pm 0.01$ & $0.35 \pm 0.04$ \\
\hline solute carrier family 41 , member 3 & Slc4la3 & $0.18 \pm 0.01$ & $0.28 \pm 0.06$ \\
\hline $\begin{array}{l}\text { solute carrier family } 7 \text { (cationic amino acid transporter, y+ } \\
\text { system), member } 4 \text { (predicted) }\end{array}$ & Slc7a4_predicted & $0.18 \pm 0.02$ & $0.31 \pm 0.04$ \\
\hline $\begin{array}{l}\text { solute carrier family } 4 \text {, sodium bicarbonate cotransporter, } \\
\text { member } 5\end{array}$ & Slc4a5 & $0.18 \pm 0.03$ & $0.16 \pm 0.05$ \\
\hline $\begin{array}{l}\text { solute carrier family } 39 \text { (zinc transporter), member } 14 \\
\text { (predicted) }\end{array}$ & Slc39a14_predicted & $0.17 \pm 0.01$ & $0.08 \pm 0.03$ \\
\hline $\begin{array}{l}\text { solute carrier family } 23 \text { (nucleobase transporters), member } 3 \\
\text { (predicted) }\end{array}$ & Slc23a3_predicted & $0.17 \pm 0.01$ & $0.09 \pm 0.01$ \\
\hline $\begin{array}{l}\text { solute carrier family } 9 \text { (sodium/hydrogen exchanger), member } \\
3\end{array}$ & Slc9a3 & $0.16 \pm 0.05$ & $0.78 \pm 0.02$ \\
\hline $\begin{array}{l}\text { solute carrier family } 35 \text { (UDP-glucuronic acid/UDP-N- } \\
\text { acetylgalactosamine dual transporter), member D1 (predicted) }\end{array}$ & Slc35d1_predicted & $0.1 \pm 0.03$ & $0.55 \pm 0.05$ \\
\hline solute carrier family 2 (facilitated glucose transporter), member & Slc2a4 & $0.1 \pm 0.01$ & $0.18 \pm 0.01$ \\
\hline $\begin{array}{l}\text { solute carrier family } 22 \text { (organic anion/cation transporter), } \\
\text { member } 9\end{array}$ & Slc22a9 & $0.08 \pm 0.01$ & $0.06 \pm 0$ \\
\hline $\begin{array}{l}\text { solute carrier family } 9 \text { (sodium/hydrogen exchanger), isoform } \\
3 \text { regulator } 2\end{array}$ & Slc9a3r2 & $0.05 \pm 0.04$ & $1.59 \pm 0.2$ \\
\hline $\begin{array}{l}\text { solute carrier family } 16 \text { (monocarboxylic acid transporters), } \\
\text { member } 13\end{array}$ & Slc16a13 & $0.04 \pm 0.02$ & $0.43 \pm 0.05$ \\
\hline solute carrier family 12 , member 4 & Slc12a4 & $0.01 \pm 0.03$ & $1.71 \pm 0.07$ \\
\hline solute carrier organic anion transporter family, member 1a4 & Slcola4 & $-0.04 \pm 0.04$ & $0.78 \pm 0.07$ \\
\hline solute carrier organic anion transporter family, member $2 \mathrm{a} 1$ & Slco2a1 & $-0.1 \pm 0.05$ & $1.47 \pm 0.14$ \\
\hline $\begin{array}{l}\text { solute carrier family } 2 \text { (facilitated glucose transporter), member } \\
13\end{array}$ & Slc2a13 & $-0.12 \pm 0.06$ & $1.61 \pm 0.11$ \\
\hline solute carrier family 14 (urea transporter), member 1 & Slc14a1 & $-0.16 \pm 0.12$ & $3.12 \pm 0.94$ \\
\hline solute carrier family 22 (organic cation transporter), member 4 & Slc22a4 & $-0.18 \pm 0$ & $1.47 \pm 0.08$ \\
\hline solute carrier organic anion transporter family, member $2 \mathrm{~b} 1$ & Slco2b1 & $-0.2 \pm 0.01$ & $1.46 \pm 0.09$ \\
\hline $\begin{array}{l}\text { solute carrier family } 1 \text { (neuronal/epithelial high affinity } \\
\text { glutamate transporter, system Xag), member } 1\end{array}$ & Slc1a1 & $-0.2 \pm 0.14$ & $4.33 \pm 0.23$ \\
\hline solute carrier family 39 (metal ion transporter), member 8 & Slc39a8 & $-0.24 \pm 0.02$ & $1.55 \pm 0.14$ \\
\hline $\begin{array}{l}\text { solute carrier family } 6 \text { (neurotransmitter transporter), member } \\
18\end{array}$ & Slc6a18 & $-0.41 \pm 0.05$ & $2.11 \pm 0.24$ \\
\hline solute carrier family 28 (sodium-coupled nucleoside & Slc28a2 & $-0.41 \pm 0.02$ & $2.07 \pm 0.13$ \\
\hline
\end{tabular}




\begin{tabular}{lllc}
\hline Gene Name & Gene Symbol & $\begin{array}{c}\text { IMCD-Signal } \\
\text { Mean } \pm \text { SE }\end{array}$ & $\begin{array}{c}\text { non-IMCD-Signal } \\
\text { Mean } \pm \text { SE }\end{array}$ \\
\hline $\begin{array}{l}\text { solute carrier family 7 (cationic amino acid transporter, y+ } \\
\text { system), member 7 } \\
\begin{array}{l}\text { solute carrier family 6 (neurotransmitter transporter, glycine), } \\
\text { member 9 }\end{array}\end{array}$ & Slc7a7 & $-0.58 \pm 0.04$ & $3.86 \pm 0.07$ \\
solute carrier family 15, member 3 & Slc15a3 & $-0.66 \pm 0.03$ & $3.26 \pm 0.1$ \\
\hline
\end{tabular}


Transcription factors

Table 14

Table 14A. Leucine zipper transcription factors.

Table 14B. Zinc finger transcription factors (partial).

\begin{tabular}{|c|c|c|c|}
\hline Gene Name & Gene Symbol & $\underset{\text { SE }}{\text { IMCD-Signal Mean }} \pm$ & $\begin{array}{c}\text { Non-IMCD-Signal } \\
\text { Mean } \pm \text { SE }\end{array}$ \\
\hline $\begin{array}{l}\text { activating transcription factor } 3 \\
\text { FBJ murine osteosarcoma viral oncogene homolog } \\
\text { Jun oncogene } \\
\text { activating transcription factor } 4 \text { (CREB2) } \\
\text { Jun D proto-oncogene } \\
\text { Jun-B oncogene } \\
\text { cAMP responsive element modulator } \\
\text { activating transcription factor } 1 \\
\text { cAMP responsive element binding protein } 3 \\
\text { cAMP responsive element binding protein-like } 1 \\
\text { cAMP responsive element binding protein } 3 \text {-like } 2 \\
\text { cAMP responsive element binding protein } 3 \text {-like } 1 \\
\text { cAMP responsive element binding protein } 1 \\
\text { basic leucine zipper transcription factor, ATF-like } \\
\text { (predicted) }\end{array}$ & $\begin{array}{l}\text { Atf3 } \\
\text { Fos } \\
\text { Jun } \\
\text { Atf4 } \\
\text { Jund } \\
\text { Junb } \\
\text { Crem } \\
\text { Atf1 } \\
\text { Creb3 } \\
\text { Creb11 } \\
\text { Creb312 } \\
\text { Creb311 } \\
\text { Creb1 } \\
\text { Batf_predicted }\end{array}$ & $\begin{array}{c}48.17 \pm 1.59 \\
35.64 \pm 1.12 \\
33.72 \pm 1.03 \\
23.41 \pm 0.21 \\
22.05 \pm 0.44 \\
12.66 \pm 1.15 \\
4.0 \pm 0.10 \\
3.54 \pm 0.10 \\
1.64 \pm 0.02 \\
1.43 \pm 0.14 \\
0.40 \pm 0.09 \\
0.28 \pm 0.01 \\
0.25 \pm 0.01 \\
0.09 \pm 0.03\end{array}$ & $\begin{array}{c}28.0 \pm 2.15 \\
36.71 \pm 2.65 \\
20.84 \pm 3.18 \\
12.61 \pm 0.33 \\
16.91 \pm 2.84 \\
7.51 \pm 1.50 \\
0.28 \pm 0.41 \\
4.57 \pm 0.30 \\
1.17 \pm 0.02 \\
1.01 \pm 0.03 \\
0.24 \pm 0.02 \\
0.29 \pm 0.03 \\
0.24 \pm 0.06 \\
0.90 \pm 0.03\end{array}$ \\
\hline $\begin{array}{l}\text { Gene Name } \\
\text { early growth response } 1 \\
\text { Kruppel-like factor } 6 \\
\text { GATA binding protein } 3 \\
\text { Kruppel-like factor } 5 \\
\text { Kruppel-like factor } 9 \\
\text { GATA binding protein } 2 \\
\text { Kruppel-like factor } 3 \text { (basic) (mapped) } \\
\text { sp1 transcription factor } \\
\text { Kruppel-like factor } 2 \text { (lung) (predicted) } \\
\text { Kruppel-like factor } 15\end{array}$ & $\begin{array}{l}\text { Gene Symbol } \\
\text { Egr1 } \\
\text { Klf6 } \\
\text { Gata3 } \\
\text { Klf5 } \\
\text { Klf9 } \\
\text { Gata2 } \\
\text { Klf3_mapped } \\
\text { Sp1 } \\
\text { Klf2_predicted } \\
\text { Klf15 }\end{array}$ & $\begin{array}{c}\text { IMCD-Signal } \pm \text { SE } \\
46.05 \pm 1.21 \\
19.18 \pm 0.18 \\
13.98 \pm 1.9 \\
9.8 \pm 0.25 \\
9.44 \pm 0.94 \\
5.31 \pm 0.42 \\
4.13 \pm 0.45 \\
1.93 \pm 0.07 \\
0.63 \pm 0.04 \\
0.53 \pm 0.01\end{array}$ & $\begin{array}{c}\text { non-IMCD- Signal } \pm \text { SE } \\
37.53 \pm 1.21 \\
9.8 \pm 0.18 \\
-2.15 \pm 1.9 \\
-0.06 \pm 0.25 \\
6.66 \pm 0.94 \\
-0.59 \pm 0.42 \\
2.31 \pm 0.45 \\
3.29 \pm 0.07 \\
2.1 \pm 0.04 \\
0.94 \pm 0.01\end{array}$ \\
\hline
\end{tabular}


Table 15

Miscelleneous

\begin{tabular}{|c|c|c|c|}
\hline Gene Name & Gene Symbol & $\begin{array}{l}\text { IMCD-Signal Mean } \\
\quad \pm \text { SE }\end{array}$ & $\begin{array}{l}\text { non-IMCD-Signal } \\
\quad \text { Mean } \pm \text { SE }\end{array}$ \\
\hline myxovirus (influenza virus) resistance 2 & Mx2 & $16.14 \pm 1.72$ & $11.22 \pm 2.14$ \\
\hline myxovirus (influenza virus) resistance 1 & $\mathrm{Mx} 1$ & $7.60 \pm 0.51$ & $2.09 \pm 0.42$ \\
\hline dynamin 1-like & Dnm11 & $2.34 \pm 0.19$ & $1.11 \pm 0.20$ \\
\hline $\begin{array}{l}\text { GTP binding protein (gene overexpressed in skeletal muscle) } \\
\text { (predicted) }\end{array}$ & Gem_predicted & $0.88 \pm 0.02$ & $5.73 \pm 0.34$ \\
\hline dynamin 3 & Dnm3 & $0.45 \pm 0.01$ & $0.45 \pm 0.03$ \\
\hline GTP binding protein 3 & Gtpbp3 & $0.39 \pm 0.01$ & $0.36 \pm 0.05$ \\
\hline dynamin 2 & Dnm2 & $0.21 \pm 0.01$ & $0.65 \pm 0.05$ \\
\hline nitric oxide synthase 3 , endothelial cell & Nos3 & $-0.13 \pm 0.02$ & $1.24 \pm 0.07$ \\
\hline nitric oxide synthase interacting protein (predicted) & Nosip_predicted & $1.11 \pm 0.09$ & $1.32 \pm 0.15$ \\
\hline $\begin{array}{l}\text { prostaglandin-endoperoxide synthase } 1 \\
\text { plide }\end{array}$ & Ptgs1 1 & $38.69 \pm 0.48$ & $-2.44 \pm 0.89$ \\
\hline $\begin{array}{l}\text { prostaglandin-endoperoxide synthase } 2 \\
\text { s. }\end{array}$ & Ptgs2 & $10.54 \pm 0.34$ & $-1.73 \pm 0.05$ \\
\hline $\begin{array}{l}\text { tyrosine 3-monooxygenase/tryptophan 5-monooxygenase } \\
\text { activation protein, theta polypeptide (14-3-3 tau, 14-3-3 theta) }\end{array}$ & Ywhaq & $37.49 \pm 1.88$ & $26.40 \pm 2.08$ \\
\hline $\begin{array}{l}\text { tyrosine 3-monooxygenase/tryptophan 5-monooxygenase } \\
\text { activation protein, epsilon polypeptide (14-3-3 epsilon) }\end{array}$ & Ywhae & $19.73 \pm 0.23$ & $10.66 \pm 1.66$ \\
\hline $\begin{array}{l}\text { tyrosine 3-monooxygenase/tryptophan 5-monooxygenase } \\
\text { activation protein, zeta polypeptide (14-3-3 zeta) }\end{array}$ & Ywhaz & $18.58 \pm 0.47$ & $8.01 \pm 1.48$ \\
\hline $\begin{array}{l}\text { tyrosine 3-monooxygenase/tryptophan 5-monooxygenase } \\
\text { activation protein, beta polypeptide (14-3-3 beta) }\end{array}$ & Ywhab & $9.76 \pm 0.17$ & $11.95 \pm 0.54$ \\
\hline $\begin{array}{l}\text { tyrosine 3-monooxygenase/tryptophan 5-monooxygenase } \\
\text { activation protein, eta polypeptide (14-3-3 eta) }\end{array}$ & Ywhah & $8.75 \pm 0.10$ & $8.03 \pm 0.53$ \\
\hline $\begin{array}{l}\text { tyrosine 3-monooxygenase/tryptophan 5-monooxygenase } \\
\text { activation protein, gamma polypeptide (14-3-3 gamma) }\end{array}$ & Ywhag & $8.07 \pm 0.23$ & $5.01 \pm 0.58$ \\
\hline
\end{tabular}

